UNIVERSIDADE DE SÃO PAULO

PROGRAMA DE PÓS-GRADUAÇÃO EM ENERGIA

EP-FEA- IEE-IF

MARCELA DADAUTO LESTINGI

A INSERÇÃO DOS CUSTOS SOCIAIS NOS EMPREENDIMENTOS HIDRELÉTRICOS: ESTUDO DE CASO DA UHE IRAPÉ (MG).

SÃO PAULO

2010 


\section{A INSERÇÃO DOS CUSTOS SOCIAIS NOS EMPREENDIMENTOS HIDRELÉTRICOS: ESTUDO DE CASO DA UHE IRAPÉ (MG).}

Dissertação apresentada ao Programa de PósGraduação em Energia da Universidade de São Paulo (Escola Politécnica / Faculdade de Economia e Administração / Instituto de Eletrotécnica e Energia / Instituto de Física) para a obtenção do título de Mestre em Energia.

Orientação: Prof. Dr. Célio Bermann

São Paulo

2010 
AUTORIZO A REPRODUÇÃo E DIVULGaÇÃo TOTAL OU PARCIAL DESTE TRABALHO, POR QUALQUER MEIO CONVENCIONAL OU ELETRÔNICO, PARA FINS DE ESTUdo E PESQUISA, DESDE QUE CITADA A FONTE.

FICHA CATALOGRÁFICA

Lestingi, Marcela Dadauto.

A inserção dos custos sociais nos empreendimentos hidrelétricos: estudo de caso UHE de Irapé, MG. / Marcela Dadauto Lestingi; orientador Célio Bermann. - São Paulo, 2010. 145p.: il.; $30 \mathrm{~cm}$.

Dissertação (Mestrado - Programa de Pós-Graduação em Energia) - EP / FEA / IEE / IF da Universidade de São Paulo.

1. Usinas hidrelétricas 2. Usinas hidrelétricas - aspectos socioeconômicos 3 Usinas hidrelétricas - construção I. Título 
"Se queremos progredir, não devemos repetir a história, mas fazer uma história nova"

Mahatma Gandhi 


\section{AGRADECIMENTOS}

A Deus, por ter me dado forças para enfrentar este desafio.

A meu orientador Prof. Dr. Célio Bermann pela oportunidade, orientação, por suas ideias e colaborações, por sua tranquilidade, paciência e amizade, que contribuíram para meu desenvolvimento profissional.

Ao Prof. Dr. Oswaldo Sevá, pelas orientações e sugestões para elaboração deste trabalho.

Ao Prof. Dr. Alfredo Wagner, por ter acreditado no potencial do trabalho; voltarei a colaborar em breve com o projeto.

À Profa. Dr. Andréa Zhouri, pelas observações que muito contribuíram para o amadurecimento do trabalho. Obrigada!

Aos novos amigos do Projeto Nova Cartografia Social da Amazônia pelo lindo trabalho que vem sendo desenvolvido, em especial Renata e Bruna (in memoriam). Descanse em paz!

A meus colegas de mestrado, em especial, Tina, Maro, Brunão, Aires, Gerusa, Físico, Francisco, Ariel, Bispo e Munir, pela alegria, amizade, carinho e convivência ao longo das disciplinas, discussões e cafezinhos.

A minha maravilhosa família, em especial, a meus pais Fátima e Wilson, por terem me ensinado tudo que sei hoje; a meu irmão Júlio, que a cada dia me surpreende mais pela inteligência e dedicação, ao meu irmão mais novo, Wilsinho, espero que possamos curtir juntos algumas coisas, a minha avó Dona Idalina, pela fé e força. Amo muito vocês!

Um agradecimento especial ao Diego que, com sua inteligência e sabedoria, me mostrou outro caminho, seu apoio foi fundamental. Amo você!

A minhas amigas-irmãs Dani, Lelê, Deh, Cris, Grá, Patrícia, Janine, Cacau, Erika e Samy por simplesmente existirem em minha vida, pela força, pela paz, pelos "cafezinhos". A distância muitas vezes não quer dizer nada. Que dure para sempre!

À Professora Marly, pela força na revisão do texto.

Ao pessoal da Secretaria, a Rosa, Adriana e agora o Cláudio, por tornarem minha vida mais fácil.

Ao Sr. José António (Comissão de Atingidos por barragens de Irapé), Sra. Celuta, Mara e Morel (FEAM), ao Wilson Grossi e Guilherme Comitti (Cemig), por terem colaborado na a execução deste trabalho. 
A todos os atingidos por barragens, que vêm demonstrando força e esperança para um mundo melhor!

A todos, que direta ou indiretamente contribuíram. Muito obrigada!

A CAPES por ter concedido a bolsa.

Obrigada! 


\section{RESUMO}

LESTINGI, Marcela Dadauto. A Inserção dos Custos Sociais nos empreendimentos Hidrelétricos: estudo de Caso UHE de Irapé, MG. 2010. 145f. Dissertação (Mestrado em Energia) - Programa Interunidades de Pós-Graduação em Energia da Universidade de São Paulo, São Paulo, 2010.

Esta pesquisa teve como proposta discutir a respeito dos "custos sociais" nos empreendimentos hidrelétricos, com base em uma análise teórica a respeito do tratamento concedido às populações afetadas por Usinas Hidrelétricas (UHE's), quando se abordam questões como indenização e compensação financeira dos meios de sobrevivência. Segundo a Constituição Brasileira de 1988, são direitos sociais de qualquer brasileiro o acesso à educação, à saúde, ao trabalho, à moradia e ao lazer. Os dados adquiridos na Companhia de Energia de Minas Gerais (Cemig) possibilitaram os questionamentos sobre a relação entre empresa empreendedora e população deslocada involuntariamente. Com essa finalidade, primeiro, fez-se um breve levantamento bibliográfico sobre o conceito de "custos sociais" e a política energética da "dam industry”. Posteriormente, realizou-se um Estudo de Caso da UHE de Irapé (MG), com um breve relato sobre o processo ambiental para a obtenção da Licença Prévia (LP), Licença de Instalação (LI) e Licença de Operação (LO), assim como o desenvolvimento do Termo de Ajustamento de Conduta (TAC) depois denominado de Termo de Acordo (TA). Na prática, tentou-se perceber como foi o "acordado" entre a CEMIG e a população e o realizado pela população, perante dados obtidos por meio de pesquisa de campo. Além disso, a pesquisa apresenta também alguns depoimentos de pessoas que moram na região, que foram afetadas, assim como dos técnicos da Federação Estadual do Meio Ambiente (FEAM) que participaram do desenvolvimento e acompanhamento do Termo de Acordo e dos representantes do empreendedor. Por meio desses dados, buscou-se uma contraposição entre o discurso técnico e o saber local para a formação do custo social nos empreendimentos hidrelétricos. É importante ressaltar que na presente pesquisa foi realizada uma análise de documentos. Isso equivale a dizer que não se pretende generalizar o caso apresentado, apenas apontar especificidades, a fim de se questionar as totalidades.

Palavras-chave: Custos Sociais. Usinas Hidrelétricas. Deslocamento Involuntário. Atingido. Reassentamento. 


\begin{abstract}
LESTINGI, Marcela Dadauto. The inclusion of social costs in hydroelectric dams: case study of UHE Irapé, MG.2010. 145f. Master's Dissertation - Post-Graduation - Inter Units Energy Related Graduate Program, Universidade de São Paulo, São Paulo, 2010.

The purpose of this research was to apresented what are the "social costs" in hydroelectric plants, from a theoretical analysis of how populations are affected by Power Plants (HPP's) are treated when, we talk about compensation and compensating financial means of survival, according to the Brazilian constitution are social rights of any Brazilian access to education, health, work, housing, leisure. The data acquired from the Energy Company of Minas Gerais (Cemig), allow questions about the relationship between entrepreneurial and involuntarily displaced population. First, it made a brief literature review on the concept of "social costs" and energy policy of "dam industry. It was later made a case study of UHE Plant, MG, with a brief account of the environmental process for obtaining the Preliminary License (LP), Installation License (LI) and Operation License (LO) and the development of the Term of Conduct Adjustment (TAC) after called the Settlement Agreement (TA). We tried to realize in practice, as was planned by Cemig and lived by the population today before data obtained from field research. In addition, research also shows some testimonials of people who live in the region that were affected as well as the technicians of the Federation State of the Environment (FEAM) who participated in the development and monitoring of the Settlement Agreement and the representatives of the entrepreneur. Using these data, we sought a contrast between the technical discourse and local knowledge for the formation of social cost in hydroelectric projects. Importantly, this research is an analysis of documents. That is to say that it is not intended to generalize the presented case, only specific point in order to question the totalities.
\end{abstract}

Keywords: Social Costs. Hydroelectric. Involuntary Displacement. Reached. Resettlement. 


\section{LISTA DE FIGURAS}

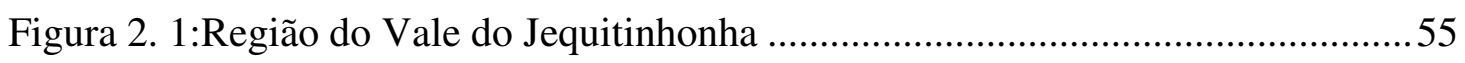

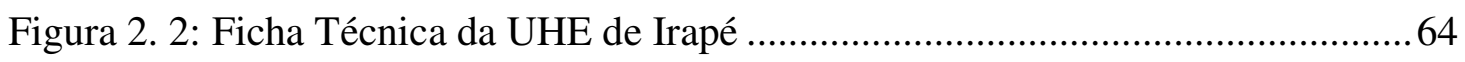

Figura 2. 3: Área de construção da Usina de Irapé .....................................................65

Figura 2. 4: Vista aérea lateral da construção da Barragem ..........................................66

Figura 2. 5: Vista Geral da Obra sem o enchimento do Reservatório ...........................66

Figura 2. 6: Área de abrangência do reservatório da Usina de Irapé ............................68

Figura 4. 1: Gradeamento de telhado exposto, com comprometimento de sua durabilidade .95

Figura 4. 2: Casa da comunidade de Porto Coris. Janela danificada devido ao empenamento da madeira..... . .95

Figura 4. 3: Parede pintada recentemente, já apresentando sinais de deterioração .96

Figura 4. 4: Fogão a lenha com aproximadamente 15 dias de uso apresentando lasca e trincas

Figura 4. 5: Porta com problema construtivo, motivo pelo qual D. Santa não mudou para a residência definitiva

Figura 4. 6: Primeira unidade residencial em construção na Fazenda Chácara .....................97

Figura 4. 7: Futura residência de D. Santa, sua filha e 10 netos ........................................ 97

Figura 4. 8: Casa na Fazenda Palhada (Autoconstrução)o ............................................... 98

Figura 4. 9: Escola Municipal Juscelino Rodrigues - Cristália, em reforma ....................... 102

Figura 4. 10: Escola do reassentamento, ainda não estava em funcionamento, os equipamentos já estão instalados, mas a fossa não tinha sido concluída e falta professor. Crianças estão sem aulas desde a transferência para a área (de 15 dias a 1 mês) ................................................... 102

Figura 4. 11: Escola em construção na Fazenda Camargo ….......................................... 102

Figura 4. 12: Terreno para plantio sem a devida preparação (calagem), rebrota de vegetação e presença de leiras. - lote 12, Faz. Riacho da Porta.....

Figura 4. 13: Presença de gado da fazenda vizinha, devido à falta de cercamento dos lotes. As áreas de plantio estão cobertas de leiras, dificultando o preparo da área.. 105

Figura 4. 14: Adubos armazenados em local inadequada - situação já relatada em fev/05.105

Figura 4. 15: Vista em detalhe da sacaria rasgada, comprometendo a qualidade do adubo. 106

Figura 4. 16: Água com aspecto turvo. Já em 2005 moradores reclamavam do cheiro e da cor da água 108 
Figura 4. 17: Tubulação com encrustamento devido a água com teor elevado de cálcio (água cálcarea), Fazenda Muquém.....

Figura 4. 18: Sistema de Captação e elevatória de água bruta (casa de bombas), Fazenda Rio Preto

Figura 4. 19: Áreas selecionadas para os reassentamentos UHE Irapé. 111

Figura 4. 20: Área destinada a construção de casa e área de plantio recém-preparada (Fazenda Planalto) 112

Figura 4. 21: Área de cultivo na Fazenda Piedade, plantio realizado no final de Jan/2005 (Detalhe das plantas de milho que não se desenvolveram).

Figura 4. 22: Fazenda Piedade em área de ocorrência de Areia Quartzoza (Classe de solo predominante em pelo menos 3 lotes) 113

Figura 4. 23: Fazenda Piedade - área destinada ao plantio com significativa densidade de formigueiros. (não relizou-se combate a pragas) 114

Figura 4. 24: Fazenda Piedade. Muda de laranjeira atacada pela formiga 114 


\section{LISTA DE TABELAS}

Tabela 2. 1: Relação de municípios atingidos com relação ao total municipal .............68

Tabela 2. 2: Identificação das comunidades atingidas por município ...........................70

Tabela 2. 3: Evolução dos Custos de Investimento Total da Obra ................................73

Tabela 3. 1: Valores médios da Terra Nua por Subclasse de Capacidade de Uso.........83

Tabela 3. 2: Indenização de Benfeitorias não reprodutivas ........................................... 86

Tabela 4. 1: Situação de construção do reassentamento...............................................90

Tabela 4. 2: Relação de Famílias reassentadas Margem Direita ................................ 115

Tabela 4. 3: Relação de Famílias reassentadas Margem Esquerda.............................. 117

Tabela 5. 1: Custos com Indenização ....................................................................... 122

Tabela 5. 2: Recurso destinado ao Desenvolvimento dos Reassentamentos ............... 122

Tabela 5. 3: Recursos destinados ao Desenvolvimento do Reassentamentos ............. 124

Tabela 5.4: Recursos destinados ao Plano de Controle Ambiental e Obras do

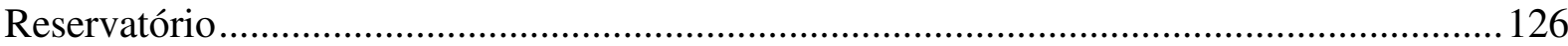

Tabela 5. 5: C Total dos Custos Sociais da UHE de Irapé .......................................... 127 


\section{LISTA DE ABREVIATURAS E SIGLAS}

$\begin{array}{ll}\text { ANEEL } & \text { Agência Nacional de Energia Elétrica } \\ \text { CAP } & \text { Conselho Atividade Agrossilvopastoris } \\ \text { CERH } & \text { Conselho Estadual de Recursos Hídricos } \\ \text { CIF } & \text { Conselho Atividades de Infraestrutura } \\ \text { CMI } & \text { Conselho Atividades Minerais } \\ \text { CONAMA } & \text { Conselho Nacional do Meio Ambiente } \\ \text { COPAM } & \text { Conselho de Política Ambiental } \\ \text { CPA } & \text { Câmara de Política Ambiental } \\ \text { CPB } & \text { Conselho Proteção à Biodiversidade } \\ \text { CPI } & \text { Conselho de Atividades Industriais } \\ \text { CRH } & \text { Conselho de Recursos Hídricos } \\ \text { EIA } & \text { Estudo de Impacto Ambiental } \\ \text { EMATER } & \text { Empresa de Assistência Técnica e Extensão Rural do Estado de Minas }\end{array}$ Gerais

FEAM Fundação Estadual de Meio Ambiente

IEF Instituto Estadual de Florestas

IGAM Instituto Mineiro de Gestão das Águas

INCRA Instituto Nacional de Colonização e Reforma Agrária

LI Licença de Instalação

LO Licença de Operação

LP Licença Prévia

PCA Plano de Controle Ambiental

TAC Termo Ajustamento de Conduta

SEMAD Sistema Estadual do Meio Ambiente e Desenvolvimento Sustentável

UHE Usinas Hidrelétricas 


\section{SUMÁRIO}

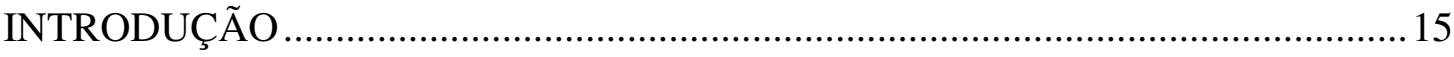

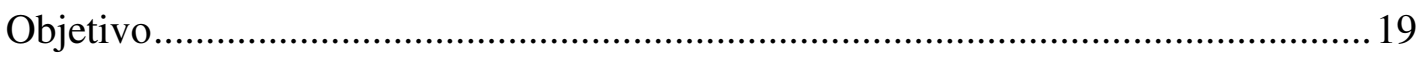

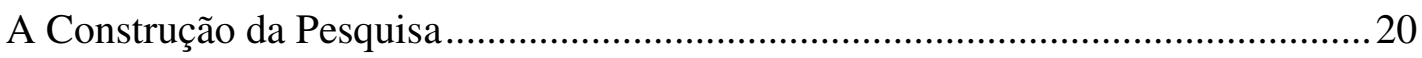

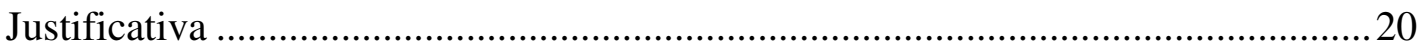

Pesquisa e instrumentos metodológicos utilizados ....................................................2 21

CAPÍTULO I - ENERGIA, DESENVOLVIMENTO OU AMEAÇA ...........................24

1.1 Identificação de Comunidades Tradicionais ...........................................................30

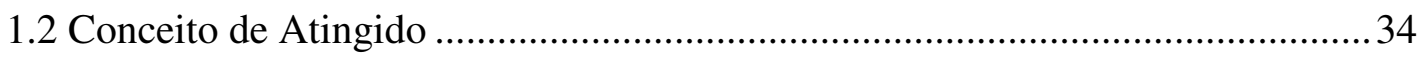

1.3 A questão social nos empreendimentos hidrelétricos ......................................... $3 \underline{8}$

1.4 Custos Sociais nas Usinas Hidrelétricas ................................................................. 44

CAPÍTULO II - CARACTERIZAÇÃO DA ÁREA DE ESTUDO................................ $5 \underline{3}$

2.1 Estrutura do Sistema Estadual de Meio Ambiente de Minas Gerais ...................5 $\underline{3}$

2.2 Localização geográfica do Vale do Jequitinhonha e suas características ............54

2.3 A UHE Irapé - Histórico do Processo de Licenciamento...................................... $\underline{59}$

2.4 Características Técnicas e área de abrangência ....................................................6 $6 \underline{3}$

2.5 Identificação do Investimento da Obra ............................................................ $7 \underline{3}$

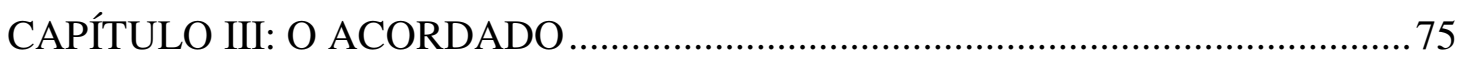

3.1 Termo Ajustamento de Conduta - TAC ……………………………………....

3.2 Metodologia utilizada para Indenização monetária de terras ou benfeitorias..... $8 \underline{0}$

3.3 Avaliação das Terras ...................................................................................... 81

3.4 Avaliação das Benfeitorias Reprodutivas e Não Reprodutivas............................... 84

3.5 Culturas Anuais ............................................................................................ 84

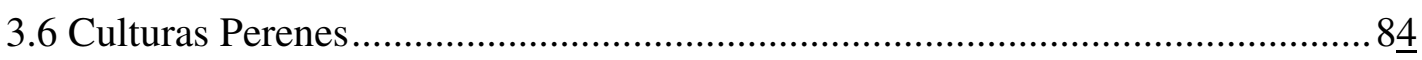

3.7 Pastagens, Essências Florestais Implantadas ………………………………...... $8 \underline{5}$

3.8 Avaliação das Benfeitorias Não Reprodutivas..................................................... 85

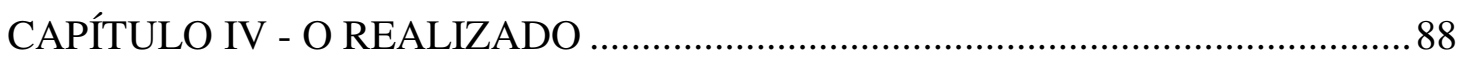

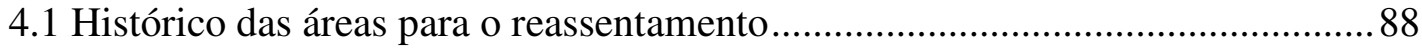

4.2 Problemas com o ano letivo para as crianças......................................................9 9

4.3 Avaliação das condições para realização do plantio da safra nas áreas de destino (Reassentamento) e da necessidade de serem destinadas medidas compensatórias às

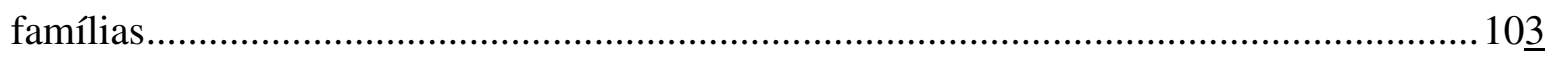

4.4 Abastecimento de Água nas Áreas de Reassentamento ......................................10 
4.5 Qualidade das terras adquiridas

4.6 Acompanhamento do processo de cumprimento das condicionantes da UHE de

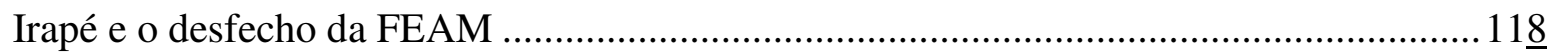

CAPÍTULO V - CUSTOS APRESENTADOS PELA CEMIG ..............................12 12

5.1 A inserção dos custos sociais nos custos de investimento ..............................12 12

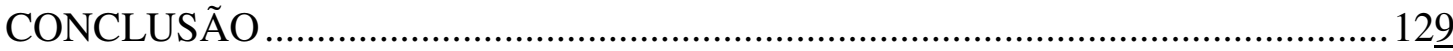

ANEXO A - E-mail Valores realizados em Irapé ...................................................... 132

ANEXO B - A luta dos Atingidos pela UHE de Irapé, Jornal local, Pelejando, outubro

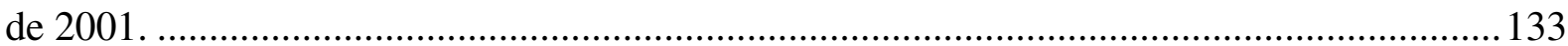

Anexo C - Condições de alguns locais de reassentamentos ...................................... 134

Condições de acessos para os reassentamentos ................................................... 134

Algumas áreas selecionadas para o reassentamento ............................................. 135

Fazenda Dallas, casas em construção .................................................................. 136

Problemas apresentados nas casas antes da chegada das famílias .......................... 137

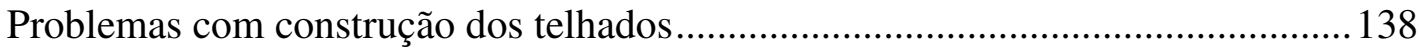

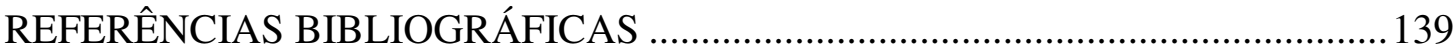




\section{INTRODUÇÃO}

A construção de usinas hidrelétricas pode ter consequências traumáticas na vida das populações que alojam os espaços destinados para esta instalação. Nesse "espaço" podemos encontrar uma diversidade de comunidades ribeirinhas dependentes de suas atribuições ecológicas para manutenção de seus modos de vida (ZUCARELLI, 2006).

Como via de regra, esses empreendimentos constituem uma ruptura nos laços sociais das comunidades que têm como resultado inúmeras transformações em seu cotidiano, isto porque na construção de usinas hidrelétricas, com o barramento de um rio, gera-se um reservatório que deixa submersas vastas extensões de terras férteis.

Durante os últimos anos, vêm se intensificando as discussões quanto às transformações que a construção de usinas causou, causa e irá causar.

Com isso, as transformações sociais vão se anunciando de forma crescente, afetando as condições de vida das comunidades e a possibilidade de sobrevivência futura, o que pede uma posição ética e responsável por parte do setor de energia.

Este trabalho apresenta os dados referentes a uma pesquisa, relativa ao delineamento dos custos sociais e suas implicações no investimento da Usina Hidrelétrica (UHE) Irapé, localizada no Vale do Jequitinhonha, em Minas Gerais. Procura mostrar como se realizam os reassentamentos de famílias atingidas pelos empreendimentos elétricos, a qualidade de compensação das terras para o reassentamento e as consequentes formas de indenização.

Visando à formulação dos conceitos dos custos sociais, o estudo pretendeu ainda fazer uma avaliação comparativa entre o acordado e o efetivamente realizado, levando em conta a definição dos padrões para a indenização no Termo de Ajuste de Conduta (TAC) firmado entre o empreendedor e a população atingida.

No entanto, existem fatores que a pesquisa não está adaptando à ótica de mercado e, ao tomar como referência a forma de contabilização, deixa escapar aspectos que estão presentes, mas que não se pretende tratar aqui.

O destaque será dado aos compromissos assumidos pelo empreendedor por meio do TAC e as compensações efetivamente realizadas, que foram oferecidas na época, considerando a limitação do trabalho.

Zhouri e Oliveira (2007): defendem que: 
de um lado, as populações que resguardam a terra como patrimônio da família e da continuidade, defendida pela memória coletiva e por regras de uso e compartilhamento dos recursos; de outro o Setor Elétrico, incluindo-se o Estado e empreendedores públicos e privados que, a partir de uma ótica de mercado entendem o território como propriedade e, como tal, uma mercadoria passível de valoração (ZHOURI ; OLIVEIRA, 2007, p.120).

Desse modo, observa-se que a construção da usina em questão trouxe consigo inúmeras transformações sociais para à população local. Demonstraremos as condições de negociação apresentadas pelo empreendedor para os atingidos, utilizando como principal fonte o Termo de Ajustamento de Conduta (TAC).

As indenizações e programas diversos de mitigação e de compensação desconsideram as especificidades e funções territoriais a serem inundadas, assim como os modos de vida e padrões culturais das comunidades atingidas.

Como sustenta Rebouças:

[...] essa gente, uma vez desapropriada e compulsoriamente deslocada, acaba sendo reassentada em lugares outros, distantes das margens do rio, nos quais e para os quais havia configurado expressivo repertório de saberes técnicos e simbólicos para fazer frente às exigências de seu singular modo de vida material e espiritual (REBOUÇAS, 2000,p.13).

Considerando a UHE de Irapé, MG, como objeto de estudo, analisaremos o reassentamento de comunidades tradicionais, perante o marco jurídico nacional, o Decreto $\mathrm{n}^{\circ}$ 6.040, de 7 de fevereiro de 2007. Colocaremos a ocupação e o uso das terras e do território como um aspecto diretamente relacionado com a identidade, assim como as formas de ocupação e o uso dos recursos naturais; as culturas e valores vinculados a essa terra ou territórios; direitos sobre os recursos naturais existentes (SHIRASHI, 2007).

O Vale do Jequitinhonha está associado à imagem do "Vale da Miséria", sua população é constituída sobretudo por camponeses pobres, sem instrução e saúde, que desenvolvem uma agricultura rústica, em terras constantemente assoladas pelas secas e vivem nas cidades sem vida que perdem população pela migração para outras regiões.

Apesar disso, essa identidade do Vale não corresponde à memória que os camponeses e as pessoas da região transmitiam sobre o passado do Jequitinhonha, quando falavam de um 
"tempo de fartura", de um tempo em que a região exportava produtos agrícolas. A partir de 1950, começou a sofrer com um conjunto de transformações significativas, associadas ao progresso de desenvolvimento capitalista brasileiro (RIBEIRO, 2008).

Estas transformações sociais deveriam ser reconhecidas pelos governos por meio de uma política ${ }^{1}$, para que se tivesse um planejamento adequado aos aspectos sociais, econômicos e culturais da população atingida. A expansão desses projetos em nome do "progresso" está se tornando cada vez mais uma "ameaça" à região de implantação, gerando, assim, grandes transformações sociais.

Ao procurar compreender os reassentamentos e o conceito de custos sociais pretendese demonstrar os meios de subsistência da população e avaliar o real papel dos empreendedores na reconstrução dos laços sociais, por meio dos recursos financeiros necessários.

Os espaços à instalação e ao funcionamento de obras desse tipo não são espaços vazios, mas, pelo contrário, locais onde vivem diferentes sujeitos sociais. Dessa forma, as populações que habitam esses lugares são retiradas, muitas vezes resistindo à expropriação.

O guia de reassentamento do Banco Mundial descreve que "devemos recordar que o ser humano é o objetivo final do desenvolvimento" ${ }^{2}$, sendo assim, é preciso proteger os grupos mais vulneráveis criados pelo próprio processo de desenvolvimento.

O reassentamento dessas pessoas pode gerar grandes transtornos, como: o empobrecimento (interrupção de atividades produtivas), quebra da rede de apoio social, danos ambientais graves a menos que medidas adequadas sejam devidamente planejadas e implementadas, portanto, o reassentamento deve ter como meta maior, garantir a recomposição da qualidade de vida das pessoas afetadas pelo empreendimento, tanto no aspecto físico, como a perda de moradia. Vale ressaltar que o desejável é que o reassentamento proporcione uma real melhoria de vida às famílias afetadas. Para isso,

${ }^{1}$ Entendemos política como Hannah Arendt descreve: só existe política se existir o diálogo, a pluralidade entre as pessoas e a liberdade. "[...] à questão sobre o sentido da política, há uma resposta tão simples e conclusiva em si mesma que se poderia pensar que as outras respostas são totalmente desnecessárias; a resposta é a seguinte: o sentido da política é a liberdade" (ARENDT, H. 1993, p.117).

2 Tradução livre da própria autora, trecho original extraído do Land Acquisition \& Resettlement Guidelines p. 7 - "We must remember that the human being is the ultimate objective of development." 
determinados fundamentos deverão nortear o planejamento dos reassentamentos: em primeiro lugar, o empreendedor deve procurar minimizar o maior número de imóveis a serem desapropriados, para que um menor número de pessoas sofra com as alterações; garantir a oferta de diferentes opções de atendimento para o reassentamento; garantia da melhoria ou da manutenção das condições de moradia; garantia da possibilidade de manutenção da renda; garantia de pagamento das indenizações pelo quantia de reposição do imóvel, incluindo todas as benfeitorias realizadas; garantia da oferta de serviços sociais: educação, saúde, transporte, etc.; busca permanente da minimização dos impactos sociais e/ou ambientais.

A forte pressão política, com o discurso governamental vinculado pela mídia e a insistência da "indústria barrageira",3 apresentam as hidrelétricas, como soluções para os problemas do País.

Originalmente, técnicas desenvolvidas e aplicadas por economistas na utilização das análises custo-benefício estenderam-se para o campo de atuação dos planejadores, como um método que lhes permitiria tomar decisões sobre projetos sociais e ambientais de forma "objetiva", "justa", "transparente", "neutra” e "democrática", uma vez que tais decisões seriam alcançadas "cientificamente" (SOARES, 2006).

Ao tentar "racionalizar" as escolhas sociais, as análises de custo-benefício tentam deslocar outras formas de discurso, como o político dos debates sobre projetos sociais e econômicos.

Como vem acontecendo ao longo da história no Brasil, as transformações sociais são particularmente acentuadas, o que resulta no empobrecimento das comunidades tradicionais ${ }^{4}$.

Cernea (1997) defende que os esforços para criar propostas de projeto com baixo custo fazem dos planejadores vulneráveis à parcialidade econômica, omissos quanto aos custos sociais reais, os atingidos são vistos pelo setor energia, como obstruções para o progresso e

3 “dam industry" influência do capital privado de empresas multinacionais nas instâncias de decisão barrageira (PINHEIRO, 2007).

${ }^{4} \mathrm{O}$ reconhecimento jurídico-formal dos povos e comunidades tradicionais, reivindicado por diferentes movimentos sociais foi firmado em outubro de 1988 no texto constitucional e foram fortalecidos por medidas implementadoras dos dispositivos constitucionais elaborados por agencias multilaterais como: ONU (Organização das Nações Unidas), UNESCO (Organização das Nações Unidas para a educação, a ciência e a cultura) e OIT (Organização Internacional do Trabalho), este conceito será apresentado no decorrer do trabalho. 
não como vítimas que querem o total suporte e recuperação de seus modos de vida e subsistência.

Tendo em vista a velocidade com que os projetos avançam para se implantar, é necessário o conhecimento mais detalhado do posicionamento das populações afetadas a respeito de suas necessidades, questionamentos e propostas.

\section{Objetivo}

O objetivo geral desta dissertação é apresentar como a noção de "custos sociais" é apreendida pela literatura para então demonstrar através do estudo de caso a apropriação de como a empresa trata com a problemática.

A partir disso, proceder a um estudo partindo da leitura de documentos, passando para a observação e a realização de entrevistas e culminando com a obtenção de histórias de vida que demonstrem o que foi acordado e o realizado. Finalmente, tentar avaliar o quanto representou do investimento total da obra a questão "social” na UHE de Irapé.

Limita-se assim, ao denominado deslocamento compulsório das populações atingidas pelas barragens, envolvendo os custos de investimento com indenização, reassentamento (compra de terras, infraestrutura e serviços) destas populações.

Para que isso aconteça, é necessário evoluir para a construção de um novo modelo econômico e social que favoreça o acesso mais justo de todos aos direitos, para além de regras do setor energia.

A consolidação das informações irá permitir demonstrar uma fase ou, se possível, a totalidade do processo de reassentamento da população de Irapé.

Scarpinella (1999) analisa a principal estratégia adotada nos empreendimentos que é a valoração monetária, através de procedimentos de análise de custo e benefício que possuem, uma série de insuficiências em razão da simplificação que este tipo de análise pode trazer. Assim, a complexidade (diversos usos da água, realocação de famílias, queda na qualidade da água, valores simbólicos, etc.) é reduzida a simples comparação de quantias monetárias, excluindo-se outras linguagens de valoração no processo de tomada de decisão. (BERMANN, et AL., 2008)

Busca-se revelar os custos de investimento com indenização e reassentamento, comparando o que foi acordado e o efetivamente realizado. Os parâmetros considerados 
referem-se à área construída, qualidade das habitações, número de hectares concedidos para cada família.

Sempre é preciso considerar não ser possível generalizar o estudo para outros empreendimentos.

\section{A Construção da Pesquisa}

Durante minha graduação em Ciências Econômicas percebia um interesse maior pelas disciplinas da área de humanas. Um professor sempre dizia que "um economista antes de tudo era um humanista", dependendo da função que desenvolve trabalha com sérias transformações socioeconômicas.

Com o objetivo de fazer uma pesquisa que me possibilitasse elaborar o trabalho de conclusão de curso e, consequentemente, o projeto de pesquisa do mestrado, participei como ouvinte do ANPPAS, em 2006, no grupo de trabalho de Energia.

Neste evento, tive meu primeiro contato com os professores da área, alunos de pósgraduação e outros trabalhos. $\mathrm{O}$ assunto que mais me chamou a atenção foi o descaso com que a população atingida é tratada pelos consórcios de hidrelétricas e também pelo interesse da indústria barrageira.

O local escolhido para o estudo de caso localiza-se no Estado de Minas Gerais, no Vale do Jequitinhonha. Nomeado de UHE de Irapé, este empreendimento pode ser visto como um caso recente. A barragem foi fechada em 8 de dezembro de 2005, atropelando uma liminar que impedia o fechamento do desvio enquanto não se cumprissem as cláusulas do TAC (Termo de Ajustamento de Conduta), no qual inúmeras famílias foram atingidas, como iremos abordar no decorrer do presente trabalho.

\section{Justificativa}

A construção de uma usina hidrelétrica implica a construção de um reservatório, o que ocasiona uma reestruturação espacial, trazendo como consequência inevitável, entre outras, a obrigatoriedade de remoção da população que habita a área a ser inundada (GERMANI, 2003).

A proposta desta pesquisa é definir o conceito dos "custos sociais nos empreendimentos hidrelétricos e identificar estes custos dentro de um Estudo de Caso, pois as 
grandes usinas promovem o deslocamento forçado dessas populações, acompanhado por compensações financeiras irrisórias e, por vezes, inexistentes. O processo do reassentamento, quando houve, não assegurou a manutenção das condições de vida anteriormente existentes. (BERMANN, 1995).

Como defende Cernea (2004), as pessoas cuja existência e modo de vida serão profundamente transformadas pelo deslocamento têm o direito de serem consultadas sobre seu futuro e ter participação nas decisões a serem feitas.

Os povos e comunidades tradicionais deverão ser consultados por meio de procedimentos apropriados, mesmo quando os recursos pertencerem ao Estado, pois eles devem participar dos benefícios e receber indenização equitativa.

$\mathrm{Na}$ análise convencional para elaboração do projeto de uma hidrelétrica, o setor de energia valoriza apenas os riscos econômicos e financeiros que podem interferir nas taxas de retorno para os investidores.

\section{Pesquisa e instrumentos metodológicos utilizados}

No desenvolvimento do trabalho, os instrumentos utilizados foram constituídos de:levantamento bibliográfico - a bibliografia disponível deve ser estudada referente ao assunto, além da obtenção das informações sobre o tema, e a pesquisa de campo no local do estudo de caso.

A metodologia proposta para avaliação deste estudo está na escolha da UHE de Irapé (MG), que será utilizada como estudo de caso. Além do estudo, a fim de demonstrar a atuação do empreendedor frente às questões sociais, a metodologia tratará da abordagem do tema, no intuito de avaliar e tentar gerar com maior clareza o significado do termo "custo social" nos empreendimentos hidrelétricos. Sendo assim, este trabalho baseia-se na coleta e sistematização dos dados referentes ao estudo de caso.

A primeira parte do trabalho, buscou a organização e a sistematização da produção acadêmica e técnica já existente sobre o termo chave e sobre a UHE de Irapé (MG), por meio de levantamento bibliográfico (livros, monografias, dissertações, teses, artigos, relatórios), assim como relatórios técnicos da UHE de Irapé, Estudo de Impacto Ambiental (EIA), Relatório de Impacto Ambiental (RIMA), Plano de Controle Ambiental (PCA). Constatou-se após esse levantamento, que o material bibliográfico disponível sobre o assunto foi limitado, uma vez que o interesse pelo assunto começou a ganhar contornos de interesse nesta época. 
A segunda parte da pesquisa (questões dirigidas) aconteceu entre 18.11.2008 a 28.11.2008. Iniciou-se com uma conversa na sede da CEMIG, em Belo Horizonte, com os responsáveis na época, por Irapé em questões socioambientais, Guilherme Comitti (coordenador do projeto da UHE de Irapé) e Wilson Grossi (Analista Ambiental) que atuam em outros projetos na área de energia.

Ainda em Belo Horizonte, houve uma reunião com Luci Rodrigues Espechit (Chefe da Divisa Operacional do INCRA-MG) do Instituto Nacional de Reforma Agrária (INCRA), para tentar entender qual o papel do Instituto nos reassentamentos. No mesmo dia, houve um encontro com os técnicos da Fundação Estadual do Meio Ambiente (FEAM), Morel Queiroz da Costa Ribeiro e Mara Adelaide Pessoa Dutra, na época, membros da equipe de fiscalização e acompanhamento das questões de reassentamento firmadas no Termo de Ajustamento de Conduta (TAC). Infelizmente, não houve o resgate de suas funções na época nem o nome completo de um dos técnicos.

No dia seguinte, já 22.11.2008 viajamos para o município de Minas Novas, a 536 Km de Belo Horizonte. Lá pretendíamos encontrar a representante da ONG Campo Vale, Sra. Conceição - peça fundamental no desenvolvimento do Termo de Ajustamento de Conduta e defesa dos atingidos. Infelizmente, durante a permanência na região, não a encontramos, mas tivemos a oportunidade de falar pelo telefone para esclarecer algumas dúvidas.

Em Minas Novas, fomos aos cartórios a fim de averiguar as questões de compra e venda das terras, para tentar identificar a quantia paga pela CEMIG, mas houve um impasse quanto a taxa a ser cobrada por certidão solicitada, cerca de $\mathrm{R} \$ 25,00$ cada.

Em 25.11.2008, viajamos para Itamarandiba a $280 \mathrm{~km}$ de Minas Novas, para participar do encontro do Colegiado de Desenvolvimento Territorial - do Alto Vale do Jequitinhonha (CODETER). Lá pudemos encontrar agricultores, artesãos, comerciantes, donas de casa, além dos representantes dos reassentados por barragens, Sr. José Antonio de Andrade (Comissão de Atingidos pela UHE de Irapé) e Sra. Celuta reassentada em Itamarandiba pelo mesmo empreendimento, todos buscando estratégias para o desenvolvimento sustentável da região do Jequitinhonha. Passamos 2 dias em discussão sobre as formas de vida e consequências da monocultura de eucalipto para a região. Ainda no encontro do CODETER, entrevistamos a Sra. Celuta.

No dia 27.11.2008, fomos para Turmalina ao encontro do Sr. José Antonio, integrante da Comissão de Atingidos pela UHE de Irapé quando o entrevistamos e traçamos um planejamento sobre as comunidades que pretendíamos visitar. Mas, em razão das chuvas que 
não paravam de cair sobre a região, as estradas de acesso as comunidades estavam intransitáveis. A partir deste cenário, decidimos encerrar a pesquisa naquele momento e voltar no período de janeiro (período de estiagem), como orientação do Sr. José Antonio para visitar as comunidades.

Contudo, não houve um retorno na data pretendida. A autora teve problemas de saúde e não consegui prosseguir com as visitas aos reassentamentos. Acredita-se que mesmo sem visitar os reassentamentos, o trabalho conseguiu atingir seu objetivo maior e pôde ser realizado.

Os depoimentos de todos os entrevistados foram gravados e transcritos de forma literal no presente trabalho. Esta opção pela transcrição literal deu-se por dois motivos: em primeiro lugar, para não se perder a riqueza da fala e, em segundo, para não dar outro sentido à fala do sujeito.

Na segunda parte do estudo houve dificuldades para localização dos responsáveis pelo processo de reassentamento na CEMIG. O encontro demorou cerca de 7 meses para acontecer. Percebeu-se ainda uma séria restrição na cessão de documentos referentes aos custos realizados pela CEMIG, bem como dificuldade quanto ao tempo de entrega desses documentos, o que atrapalhou o andamento do trabalho. 


\section{CAPÍTULO I - ENERGIA: DESENVOLVIMENTO OU AMEAÇA}

Eu visitei os reassentamento, em Pernambuco, que é da barragem de Itaparica, e o depoimento das mulher lá é o seguinte: "hoje, eu sou uma trabalhadora rural que se tornei uma bóia fria, porque, porque eu tô aqui num povoado, num aglomerado e tô andando 10 a 15 kilômetros pra pode trabaiá na roça (Entrevista com Sr. José Antonio - Comissão dos Atingidos por Irapé, 27/11/2008, Turmalina, MG)

De acordo com estudos apresentados nas últimas décadas, o consumo de energia vem aumentando e está diretamente relacionado ao desenvolvimento do parque industrial, à modernização da agricultura, ao aumento da capacidade de consumo da população e à elevação dos níveis de conforto individual e familiar.

Se esta pressão de consumo não for atendida em tempo hábil, o País poderá mergulhar no círculo vicioso: para estimular o desenvolvimento necessita de energia; para produzir energia precisa de recursos de que, muitas vezes, não dispõe (BERMANN, et al., 2008).

O aproveitamento hidrelétrico é obtido pela utilização do potencial hidráulico de um determinado trecho de um rio, pela construção de uma obra de engenharia conhecida como barragem. Esta construção traz como consequência a formação de um reservatório que inunda vastas extensões de terras e as apropriações em seu entorno.

Assim, a geração de energia por meio de usinas, habitualmente, vem promovendo um processo acelerado de transformações locais, não apenas nas áreas onde estão instaladas, como também no domínio das relações sociais, ambientais, econômicas e políticas. Com base na construção deste modelo, inúmeras situações se transformam, é uma dinâmica que se sobrepõe na vida dos que ali residem e trabalham (SEVÁ, 2008, p.1).

O País está condicionado a pensar que a fonte hídrica é a única solução, o que está acarretando uma grande ruptura nos laços sociais da população onde as obras são construídas.

Entretanto, ao contrário da ideia de que o consumo está relacionado ao desenvolvimento, à participação de indústrias eletrointensivas no consumo de eletricidade do país - cerca de $27 \%$ do consumo total - indica a forma com que o Brasil está se inserindo no mercado, como produtor de bens de alto consumo energético e baixo valor agregado. Estes processos caracterizam-se pelo alto grau de poluição e pela grande demanda de recursos naturais (BERMANN, 2008). 
Trata-se da "cultura" da hidroeletricidade", cuja necessidade maior é a geração de energia elétrica para atender ao mercado internacional, o que se torna cada vez mais uma das maiores preocupações dos pesquisadores da área. De acordo com o conceito técnico, "impacto ambiental" é definido pela resolução 001/86 do Conselho Nacional do Meio Ambiente (CONAMA) como:

[...] qualquer alteração das propriedades físicas, químicas e biológicas do meio ambiente, causada por qualquer forma de matéria ou energia resultante de atividades humanas, que direta ou indiretamente, afetam a saúde, a segurança e o bem estar da população; as atividades sociais e econômicas; a biota; as condições estéticas e sanitárias do meio ambiente; e a qualidade dos recursos ambientais (CONAMA, 1986).

Estes impactos, quando identificados pelo Estudo de Impacto Ambiental (EIA), não demonstram na íntegra toda a região, suas quantias e características. Percebe-se que os Estudos de Impacto Ambiental são desenvolvidos de forma a beneficiar o contratante, já que a avaliação não possui caráter imparcial, o que torna o documento um instrumento favorável ao empreendedor e distante da finalidade de minimizar os impactos - transformações na região como, aborda Rothmann:

os autores apontam que, sob o "paradigma da adequação", os consultores contratados para a elaboração dos EIA/RIMAS financeiramente dependentes dos empreendedores - tendem a elaborar estudos que concluem pela viabilidade ambiental dos projetos (ROTHMANN, 2008, p.26).

No mesmo sentido, outro autor demonstra a falta de compromisso por parte dos consultores.

Aparentemente, estes "impactos ambientais" são colocados por meio de critérios pouco transparentes pelos consultores que são contratados pelos futuros interessados na obra de geração de energia. Neste caso, os empreendedores, "o conhecimento produzido foi forjado no interior de empresas de consultoria e instituições de pesquisa que seguiam um roteiro de análise em conformidade com os interesses dos órgãos proponentes (REBOUÇAS, 2000, p.17).

\footnotetext{
${ }^{5}$ Para aprofundar, buscar PINHEIRO, 2007.
} 
As empresas consultoras formam um lobby que funciona em função da construção dos setores de infraestrutura, barragens, pontes e estradas.

Integram este lobby empresas consultoras encarregadas do planejamento do setor, algumas das maiores empresas da construção civil do país, empresas que produzem equipamentos elétricos e empresas que necessitam de muita energia para se implantar, como é o caso da indústria de alumínio da Região Norte (SIGAUD, apud REBOUÇAS, 2000, p.103).

A indústria hidrelétrica está bem apresentada no que Mc Cully denomina de "dam industry" ou "indústria barrageira", ou em seu texto denominado "indústria de las represas"

Apesar de los terribles antecedentes a nivel social, ambiental y econômico de las grandes represas, y de la existência de otras formas de proveer energia y manejar el suelo y el água, todavía se proponen y se construyen estos enormes proyectos. El monstruo destructivo de la industria de las represas se mentiene vigente porque la construccion de las mismas beneficia a poderosos intereses políticos y econômicos y, además, porque el processo de planeamiento, promoción y construcción de las represas generalmente se realiza em forma secreta y sin um consentimiento democrático (MC CULLY, 2001 apud PINHEIRO, 2007 p. 10).

Antigamente, as obras de infraestrutura, como a construção de hidrelétricas eram vistas como grandes obras, uma vitória para a categoria dos engenheiros e construtores. Hoje, traduzem o sofrimento e a tristeza de se ver um rio barrado, afogado, morto. A partir da construção desses empreendimentos, ocorrem diversas transformações na vida social de inúmeras pessoas que vivem em seu entrono, como expressado por Sevá.

Trata-se de rupturas e violações: a destruição dos monumentos fluviais mais maravilhosos do planeta; a acumulação primitiva de capital, fundada na expropriação dos pobres e dos nativos; a especulação e a concentração fundiária de milhares de hectares a cada represa (SEVA 2008, p.46).

A Constituição Federal de 1988 exige o prévio licenciamento ambiental para a instalação de atividades efetiva ou potencialmente degradadoras dos recursos ambientais, de acordo com o artigo $225 \S 1^{\circ}$, IV. A Lei Federal $n^{\circ}$. 6.938, de 31 de agosto de 1981, dispõe sobre a Política Nacional do Meio Ambiente e enumera, dentre os instrumentos da política 
ambiental, a avaliação de impactos ambientais, o licenciamento e a revisão de atividades efetiva ou potencialmente poluidoras (artigo $9^{\circ}$, inciso III e IV), porém a Lei deveria garantir o cumprimento da legislação em vigor, assim como a participação da sociedade civil por meio de Audiência Pública (BRASIL, 1988).

A partir da crise energética ocorrida em 2001, houve uma alteração nos processos de licenciamento a fim de adiantar a construção de usinas pela publicação da Medida Provisória $\mathrm{n}^{\circ} .2 .147$, de 15 de maio de $2001^{6}$.

O processo de licenciamento ambiental tem sido um dos mais criticados por empreendedores e pelo próprio governo pelo atraso no cronograma das obras e, com frequência, a questão ambiental é vista como "entrave", para a construção de barragens (ZHOURI; OLIVEIRA, 2005; PINHEIRO, 2007).

Não somos contra a geração de hidroeletricidade, o que é se mostra inaceitável "é que, sob o pretexto de produção de energia "limpa", se dê prosseguimento a uma política autoritária e irresponsável social e economicamente (SIGAUD, 1988, p. 106).

Desse modo, a construção de uma hidrelétrica é regulada na legislação brasileira por decretos, leis e deliberações normativas estaduais.

O Ministério de Minas e Energia (MME) detém os estudos dA estimativa do potencial hidrelétrico dos rios brasileiros. Com base nesse levantamento, é feita uma análise da bacia hidrográfica quanto à exploração do empreendimento almejado, como também nos "estudos de inventário hidrelétrico" (ZUCARELLI, 2006).

Com bases nessas informações, os interesses em explorar o potencial energético de outras localidades precisam entrar com o requerimento de Licença Prévia para iniciar os estudos de viabilidade que oferecerão suporte técnico ao processo de concessão. A Portaria do MME gerenciada pela Agência Nacional de Energia Elétrica (ANEEL) coordena todo o processo de licitação, desde o lançamento do edital até a assinatura do contrato de concessão.

As hidrelétricas incluem barragens construídas sobretudo para fins de geração de energia elétrica. Promovem outros benefícios para a qualidade de vida humana, como irrigação de culturas, canais de navegação e controle de cheias. No entanto, trazem também

\footnotetext{
${ }^{6}$ Foi estabelecido o prazo de 6 meses para o licenciamento ambiental.
} 
transformações sociais e ambientais que incluem os custos sociais como o reassentamento de populações humanas em áreas distantes daquelas originalmente inundadas.

Como "grandes obras as hidrelétricas sempre foram apresentadas como ícones de desenvolvimento, símbolos de modernidade e progresso" (ZHOURI, 2004). Contudo as barragens passaram a ser palco de grandes conflitos.

De acordo com Zhouri (2004), os movimentos sociais surgidos no mundo, a partir de 1960, foram acompanhados por debates intelectuais que buscavam novas bases para as Ciências Sociais.

A partir desse momento, houve o surgimento de uma crítica ambiental sobre a sociedade industrial que se denominou no movimento nomeado "ecologia política". Este faz uma crítica em relação aos crescentes custos de reprodução do sistema. A ecologia política vai além das contradições do modo de produção capitalista, afirma-se uma alienação entre a sociedade industrial e a natureza (ZHOURI, 2004).

Neste processo, muitas organizações e movimentos ambientalistas foram convidados à participação e à parceria.

Portanto, os conflitos inerentes aos grandes empreendimentos passaram a ter uma atribuição de significados, assim como a apropriação e o uso dos territórios são permitidos com base nas tensões entre os interessados e portadores de distintos interesses passíveis de negociação.

[...] aqueles envolvendo grupos sociais com modos diferenciados de apropriação, uso e significação do território, tendo origem quando pelo menos um dos grupos tem a continuidade das formas sociais de apropriação do meio que desenvolvem, ameaçada por impactos indesejáveis (ACSELRAD, 2004, p. 212).

É preciso que o Setor Elétrico tenha um melhor preparo para lidar com as questões dos deslocamentos involuntários, com vistas à obtenção de uma sociedade mais justa e democrática. Podemos classificar o desenvolvimento do setor energético como: "[..] uma rota que tem sido destrutiva, plena de eventos rebaixadores da Condição Humana, um rota violadora de direitos e aniquiladora de identidades" (SEVÁ, 2008, p.2).

A resposta, certamente, é que as críticas sobre as transformações dos projetos de construção de Usinas Hidrelétricas há muito tempo deixaram de ser apenas ambientais e passaram a ser sociais, em razão das transformações radicais, sociais e econômicas sofridas pela população atingida da região do empreendimento. 
A partir da especulação do projeto de construção de usinas hidrelétricas, os impactos gerados são considerados pelos especialistas da área como de grande transformação social e estas deveriam ser reconhecidas pelos governos por meio de uma política, para que se tenha um planejamento adequado quanto aos aspectos sociais, econômicos e culturais da população atingida.

Esses rumores geram os primeiros impactos já que produzem incerteza na população, que se questiona se pode continuar com sua vida normal: períodos de semeadura, investimentos, aquisições, entrada nas escolas, etc (CORTES, 1999 apud VAINER, 2003, p 12).

Em muitos países, com um bom aproveitamento hídrico, as construções de hidrelétricas representam ótimas soluções para o setor energético. O Brasil é um destes que, infelizmente, utiliza a fonte hídrica como fonte de energia "renovável" e "limpa", o que torna crescente o cenário de injustiça ambiental ${ }^{7}$.

Apoiadas nesses rumores, dezenas de famílias deixam muitas vezes de plantar, receosas de perder tudo e não serem recompensadas. Desse modo, a expansão desses projetos em nome do "progresso" está se tornando cada vez mais uma "ameaça" à região de implantação, gerando, assim, grandes conflitos.

Com a reestruturação do setor elétrico, a inserção da iniciativa privada, estabeleceu novos parâmetros de financiamento, o que "promoveu o estímulo à autossuficiência energética aos grandes consumidores industriais” (ZHOURI, 2004).

Assim, existe uma redução do uso múltiplo do rio a uma única finalidade, o que impõe altos custos sociais decorrentes de sua implantação que são arcados pelas comunidades atingidas e pela sociedade, em geral.

Portanto, deve-se estar muito atento a tais consequências, mesmo que tudo isso possa ser aceito em função do progresso e da modernidade. A ideia de se utilizar mais energia parece algo adquirido pela sociedade em quase todo o mundo, e na perspectiva atual, o

${ }^{7}$ Zhouri; Oliveira (2007) entendem que a concepção hegemônica de desenvolvimento e progresso, símbolos de atitude e política empreendedora no caso as barragens, atingindo os segmentos mais vulneráveis da sociedade brasileira - minorias étnicas como indígenas e quilombolas- e as populações ribeirinhas são geradoras de "injustiça ambiental". 
suprimento de energia terá de ser providenciado e administrado por muitas gerações a longo prazo (BERMANN et al., 2008).

Para a disponibilização de energia elétrica à sociedade, os aproveitamentos energéticos prescindem da apropriação prévia do "espaço ambiental"8. O processo caracteriza-se pelo embate de duas concepções distintas de território: a primeira, a dos empreendedores que o concebem como mercadoria a ser apropriada e gerenciada para geração de energia elétrica; e a segunda, a dos atingidos que, por sua vez, veem o espaço como depositário de sua afetividade, sua sobrevivência e sua vida.

\subsection{Identificação de Comunidades Tradicionais}

Na Constituição Federal de outubro de 1988, houve o reconhecimento jurídico formal dos povos e comunidades tradicionais. Assim, após 14 anos, com a constante batalha dos movimentos sociais, e ressaltando o caráter de "terras tradicionalmente ocupadas, o governo brasileiro ratificou, em junho de 2002, por meio do Decreto Legislativo $\mathrm{n}^{\mathrm{o}}$. I43, a convenção I69 da Organização Internacional do Trabalho, que é de junho de 1989” (SHIRAISHI, 2008, p. 9). Como se pode perceber, há 14 anos já eram reconhecidos como critérios os elementos de autoidentificação das comunidades.

Em seu Art. 14. a Convenção Internacional do Trabalho afirma os seguintes termos de dominialidade e direitos territoriais "dever-se reconhecer aos povos interessados os direitos de propriedade e de posse sobre as terras que tradicionalmente ocupam" (OIT, 1989).

O sentido "tradicional" assim nomeado, baseado na articulação entre a Convenção I69 (OIT) e a Convenção Sobre Diversidade Biológica ${ }^{9}$ (CDB), provém da noção de “comunidades locais", como apresenta Shiraishi (2008), antes denotava sobretudo um tributo ao lugar geográfico e a um suposto "isolamento cultural", contudo o termo ainda aparece envolvido como que em um processo de construção.

${ }^{8} \mathrm{O}$ “espaço ambiental” é entendido como espaço geográfico efetivamente utilizado por um determinado grupo social considerando tanto o acesso aos recursos naturais, como a destinação de seus efluentes e emissões (Martínez, 1999 apud Zhouri; Oliveira, 2005).

${ }^{9}$ Texto firmado durante a Conferência das Nações Unidas sobre meio ambiente e Desenvolvimento Rio de Janeiro, de 5 a 14 de junho de 1992 - e aprovado pelo Senado Federal pelo Decreto Legislativo nº 2, de 1994. 
Em junho de 2006, a Comissão de Desenvolvimento Sustentável das Comunidades Tradicionais foi criada por Decreto, com o objetivo de inserir uma política nacional essencialmente dirigida. Assim o Art. 15 da Constituição garante a todos o pleno exercício dos direitos culturais.

Apoiados em Almeida; Shiraishi foi possível identificar dispositivos jurídicos que foram "acordados", "assinados" e "ratificados" pelo Brasil, com referência aos povos e comunidades tradicionais do País.

Desde 1980, o antropólogo, professor e pesquisador Alfredo Wagner Berno de Almeida "vem tentando sistematizar as diversas situações sociais que são vivenciadas por esses povos e comunidades tradicionais" (SHIRAISHI, 2008, p.26).

No Brasil, existe um grande histórico de mobilização para o reconhecimento dos direitos, "organizados" pelos povos indígenas, quilombolas, seringueiros, castanheiros, quebradeiras de coco babaçu, ribeirinhos, faxinalenses, entre outros.

No contexto global, chama atenção a falta pelo qual os diversos países vêm tratando as questões, estas vem oscilando entre o reconhecimento e a negação de direitos. Como exemplo, utilizam a discriminação à imigração, "utilizando critérios seletivos, onde a maior escolaridade e o padrão econômico são determinantes" (SHIRAISHI, 2008, p.26).

Contrariando as medidas discriminatórias que acontecem em alguns países, a América Latina tem alterado seus dispositivos jurídicos, reconhecendo o "caráter "pluricultural" e "multiétnico" de suas sociedades" (TOMEI; SEWPSTON, 1999 apud SHIRAISHI, 2008, p.27). Neste sentido o Brasil tem se orientado diante dos dispositivos jurídicos internacionais para reconhecer as diferenças existentes e vem objetivado melhorar as relações sociais "o atendimento às demandas oriundas dos grupos sociais", a fim de preservar a pluralidade como valor para a democracia. (REALE, 1963 apud SHIRAISHI, 2008, p.28).

O processo de reconhecimento das questões de "pluralidade" é multiétnico e vem refletindo diretamente nas práticas jurídicas, o que requer a abertura de outras interpretações jurídicas que implicam o afastamento direto das práticas atuais. 
Isso decorre do fato do Direito não conseguir responder às reivindicações dos grupos sociais. $\mathrm{O}$ desrespeito às diferenças entre os grupos sociais vem provocando o aprofundamento dos problemas.

Atualmente é o Direito Ambiental que vem sendo apresentado e difundido, como um direito de todos, como consta no Art. 225 da Constituição Federal de 1988 "Todos têm o direito ao meio ambiente ecologicamente equilibrado, bem de uso comum do povo essencial à sadia qualidade de vida" (Art. 225 CF, 1988 apud SHIRAISHI, 2008, p.29). Ele trata mais da conservação do meio ambiente e não da preservação da forma de vida das comunidades. Como por exemplo, temos a criação das Reservas Extrativistas criadas pelo próprio órgão Federal que acabam trazendo sérias transformações para as comunidades locais, uma vez que não conseguem mais atuar com suas práticas, pois estão dentro de uma reserva. A situação mostra-se contraditória, pois se a área encontra-se em tal estado até aquele momento, significa que as comunidades que habitam aquele espaço, fazem parte do processo de preservação.

Assim, os direitos devem ser plenos para garantir aos povos e as comunidades tradicionais uma prática social de "criar", "fazer" e "viver". Mas, observa-se que "o direito tal como tradicionalmente formulado, tem servido como "obstáculo" às pretensões dos povos e comunidades tradicionais, evidenciando o grau de disputas internas no campo jurídico, em que se coloca em questão a própria forma de dizer o direito" (SHIRAISHI, 2008, p.31).

A busca do reconhecimento desses direitos pelos movimentos, ou seja, o direito de viver a diferença, faz com que se exija uma prática diferenciada do direito tradicional. Por esta razão, os "operadores do direito" devem ter um comportamento diferenciado dentro das necessidades das comunidades tradicionais.

Segundo Shiraishi (2008), faz-se necessário, portanto, que o direito seja apresentado de uma forma que o pensamento jurídico atual sinalize a produção e a interpretação de estruturas mais livres dos esquemas dominantes que, atualmente, "aprisionam o pensamento jurídico", para entender o significado da "sociedade pluralista", que está em constante transformação. 
No caso das situações sociais que envolvem os povos e comunidades tradicionais, entendo que se trata de atribuir ao "princípio da pluralidade" o mesmo valor que é atribuído ao "princípio da dignidade humana", que de forma criteriosa tem orientado a elaboração de toda a dogmática crítica do direito (SHIRAISHI, 2008, p.32).

Como defende Shiraishi (2008), é preciso atualizar as práticas tradicionais, não se trata mais de utilizar os mecanismos jurídicos para uma simples interpretação, é necessário algo composto por diversos instrumentos para a real efetivação dos direitos, ampliando assim as possibilidades de interpretação e de efetivação de direitos.

O modelo vivenciado pelas comunidades tradicionais põe em "xeque" o direito, à medida que obriga o reconhecimento de outros mecanismos jurídicos.

Por, isso trata se de refletir sobre os esquemas de pensamento jurídico dominantes, cuja implicação primeira é rever determinadas noções e princípios profundamente cristalizados e que se encontram inculcado" nos "operadores de direito (SHIRAISHI, 2008, p.32).

Baseada nisso, observa-se que a forma indicada e a mais coerente é atribuir ao direito "princípio da dignidade humana, favorecendo a pluralidade. Contudo, essa postura implica uma "nova maneira" (SHIRAISHI, 2008) de pensar que, vem sendo abordada em Declarações e Convenções Internacionais, que reconhecem as comunidades que vivem de modo diferenciado da grande maioria, como algo a ser preservado e respeitado por todos.

Os dispositivos jurídicos tanto os internacionais como os nacionais utilizam diferentes termos para representar a mesma situação, "que dizem respeito aos grupos sociais portadores de identidade étnica e coletiva" (SHIRAISHI, 2008. 42). O autor citado ${ }^{10}$ identificou os termos utilizados: Populações indígenas, Populações locais, Populações extrativistas, Populações tradicionais, Comunidades Indígenas, Comunidades locais, Comunidades tradicionais, Povos indígenas, Povos tribais, Povos autóctones e Minorias (SHIRAISHI, 2008, p.42-44).

${ }^{10}$ Para se aprofundar no assunto ler Shiraishi , Joaquim Neto; Almeida, Alfredo Wagner Berno de, ou procurar por Projeto Nova Cartografia Social dos Povos e Comunidades Tradicionais do Brasil (UFAM/F. FORD/MMA). 
No Brasil, a Comissão Nacional de Desenvolvimento Sustentável dos Povos e Comunidades Tradicionais institui a Política Nacional de Desenvolvimento Sustentável dos Povos e Comunidades Tradicionais, por meio do Decreto 6.040, de 7 de fevereiro de 2007. Incluíram-se no conceito de populações tradicionais, antes restrito a indígenas e quilombolas, grupos como pantaneiros, caiçaras, ribeirinhos, seringueiros, castanheiros, quebradeiras de coco de babaçu, geraizeiros e ciganos, entre outros.

Em seu Art $3^{\circ}$ o Decreto compreende:

I - "Povos e Comunidades Tradicionais: grupos culturalmente diferenciados e que se reconhecem como tais, que possuem formas próprias de organização social, que ocupam e usam territórios e recursos naturais como condição para sua reprodução cultural, social, religiosa, ancestral e econômica, utilizando conhecimentos, inovações e práticas gerados e transmitidos pela tradição;" (Decreto n. ${ }^{0} 6.040$ de 7 de fevereiro de 2007).

II - "Territórios Tradicionais: os espaços necessários a reprodução cultural, social e econômica dos povos e comunidades tradicionais, sejam eles utilizados de forma permanente ou temporária, observado, no que diz respeito aos povos indígenas e quilombolas, respectivamente, o que dispõem os arts. 231 da Constituição de 68 do Ato das Disposições Constitucionais Transitórias e demais regulamentações; e" (Decreto n. ${ }^{\circ} 6.040$ de 7 de fevereiro de 2007).

III - "Desenvolvimento Sustentável: o uso equilibrado dos recursos naturais, voltado para a melhoria da qualidade de vida da presente geração, garantindo as mesmas possibilidades para as gerações futuras". (Decreto n. ${ }^{\circ} 6.040$ de 7 de fevereiro de 2007).

\subsection{Conceito de atingido}

Como marco no cenário internacional e nacional, em 2000, a Comissão Mundial de Barragens publicou um Relatório intitulado, "Represas e Desenvolvimento: um novo marco para a tomada de decisões" que aponta que de 40 a 80 milhões de pessoas foram deslocadas por grandes barragens nos últimos 50 anos. (WORLD COMMISSION ON DAMS, 2000).

No Brasil, o Movimento de Atingidos por Barragens (MAB) estima que 1 milhão de pessoas foram deslocadas de suas propriedades, suas moradias e locais de trabalho, em todo o País (MAB, 2005). 
Infelizmente, os projetos que visam à construção de usinas hidrelétricas ainda estão acontecendo, em função das metas estipuladas pelos Programas Federais como o Programa de Aceleração do Crescimento (PAC) - programa criado pelo Governo Federal em 28 de janeiro de 2007, no qual estão previstos grandes investimentos em infraestrutura. A área de energia caracteriza-se como sendo o principal para o desenvolvimento do programa, com projetos “insanos" como: as Usinas do Rio Madeira, no Rio Madeira e a UHE de Belo Monte, no Rio Xingu/PA.

Como defende Colito (1999), os discursos são uma proposta à luz de uma "ideologia da modernização", nos quais os setores responsáveis não se preocupam com as transformações que ocorrem no ambiente natural. Desta forma, as barragens foram sendo impostas como algo positivo que trariam o desenvolvimento local para a população, sem se preocupar com as transformações do espaço onde habitam.

A partir da produção acadêmica existente, iremos apresentar o conceito de atingido. Segundo Vainer podemos entender como Atingido:

Ao abordar o conceito de atingido cabe deixar claro o contexto e o sentido do debate, de modo a explicar o que é que está em jogo. $\mathrm{Na}$ verdade, embora o termo apareça em documentos técnicos e remeta a dimensões econômico-financeiras, a noção não é nem meramente técnica, nem estritamente econômica. Conceito em disputa, a noção de atingido diz respeito, de fato, ao reconhecimento, leia-se legitimação, de direitos e de seus detentores. Em outras palavras, estabelecer que determinado grupo social, família ou indivíduo é, ou foi, atingido por determinado empreendimento significa reconhecer como legítimo $-e$, em alguns casos como legal - em seu direito a algum tipo de ressarcimento ou indenização. Para a reabilitação ou reparação não pecuniária. Isto explica que a abrangência do conceito seja ela mesma, objeto de uma disputa (VAINER, 2003, p.1).

A partir do momento que foi feita a legitimação, o reconhecimento, o termo atingido pode variar no que diz respeito à cultura, podendo ser: proprietários, não proprietários, meeiros, garimpeiros, posseiros, pescadores, agricultores, quilombolas, povos indígenas, ribeirinhos, assim como cidadãos do meio urbano. Para a condição de não proprietário, podese entender que ele habita o território, porém, não detém a posse de documentos, pode-se 
perceber que, a ocupação do território, em sua maioria, é tida com "informalidade" $\left(\mathrm{BARBOSA}^{11}\right)$.

Existe também uma "concepção hídrica", que identifica atingido como inundado. neste caso, o atingido, para os empreendedores, representa apenas aquele que teve suas terras inundadas (VAINER, 2008, p. 43). No entanto, atingido é também quem sofre as consequência com o deslocamento da comunidade, tendo seu comércio ou seus laços de relacionamento afetados pelo enchimento do reservatório.

Os receptores ou os municípios que recebem os atingidos para serem realocados, podem sofrer mais acentuadamente as consequências da implantação de uma usina, pois, muitas vezes, não possuem infraestrutura básica, como: saneamento, água tratada, escolas, hospitais, emprego, podendo, desta forma, deixar os atingidos em situações piores que aquelas em que se encontravam antes.

Trata-se de pessoas, cuja sobrevivência sempre esteve vinculada a condições específicas de uso ou ocupação do território, associam atividades de cultivo da terra à pesca e caça.

Portanto, as questões como o ressarcimento dos danos sofridos: perda da moradia, emprego, meios de subsistência não cabem ao conceito de atingido. Este é aquele que reconhece quem tem o direito de rever seus bens materiais e quem sofrerá com a perda dos bens imateriais que indicamos como limitação desta dissertação.

Nesse sentido, a população atingida, assim como os usos que faz da água e todas as atividades são considerados como obstáculos ao projeto, no qual o critério utilizado é que os custos econômicos devem ser "minimizados".

Como apontam Vainer (1990); Viana (2003), o setor elétrico utiliza uma estratégia “Territorial Patrimonialista" e só reconhece como atingidos os que possuem o direito de propriedade, cuja apropriação das terras ocorre por meio do mecanismo legal da compra e venda e desconhece qualquer direito social ou territorial dos não proprietários, dispensando a empresa dos "custos sociais" impostos a essa parte da população.

${ }^{11} \mathrm{O}$ artigo foi publicado em um Congresso, porém não identificamos a data de publicação, disponível em: < http://sg.cier.org.uy/cdi/cier-zeus.nsf/752a4962ef6482ff03256f050077c9f7/3879F1D78D1ABF01832575AE0054D386/\$FILE/040.pdf> . 
Uma segunda estratégia, apontada por Vainer (1990) e Viana (2003), utilizada pelo setor de energia é a desinformação; desta forma, a população não se dá conta do que há por vir. No segundo momento, acontecem atividades de comunicação social que trabalham com informações distorcidas sobre os benefícios da obra, sem informar as transformações que a região irá sofrer. Vainer (1990) cita que "isso facilita a ação da empresa”.

Por fim, a terceira estratégia é a negociação individual, proprietário por proprietário em lugar de uma negociação coletiva. O objetivo desta negociação é "impedir ou dificultar a discussão e organização coletivas. Para a empresa a população não existe enquanto coletividade/comunidade, mas apenas como um somatório de proprietários indivíduos" (VIANA, 2003, p. 36).

Como aponta Viana (2003), uma das grandes conquistas dos movimentos de atingidos é a "ampliação e consolidação do conceito de atingido", obtido nos últimos tempos. O próprio Banco Mundial, um dos maiores financiadores de projetos de infraestrutura, entende e reconhece que:

Populações indígenas, minorias étnicas, camponeses e outros grupos que tenham direito informal à terra e outros recursos expropriados pelo projeto,devem ser ressarcidos adequadamente com terra, infraestrutura e outras compensações. A ausência de título legal de propriedade não deve ser utilizada para negar a tais grupos compensação e reparação (WORLD BANK, 1994, EXECUTIVE SUMARY, BOX 1 apud VIANA, 2003, p.36).

Contudo, diversidade e a especificidade dos valores e tradições, bem como das formas sociais de relacionamento com os recursos naturais e experiências políticas e organizativas tornam as transformações sociais, em questões individuais em cada projeto, em função de cada região e comunidade. 


\subsection{A questão social nos empreendimentos hidrelétricos}

A gente sabe quem só mora num tem direito, mas e eu que vivo aqui há mais de 20 anos e a bem dizer toco essa propriedade pro dono que faz uns 10 anos num pisa aqui. A minha casa fui eu que levantei, vou ter de sair com minhas coisas nas costas como fosse um vadio, eu que sou trabalhador desde criança. Eu num tenho pra onde ir, vou ter que ficar com a mulher e as panelas no mundo sem rumo? (atingido pela UHE Serra do Facão; MPF, 2004, p.384).

Em função das inúmeras transformações ocorridas nos locais de implantação das empreendimentos hidrelétricos, o trabalho pretende identificar e apresentar as transformações sociais causadas pelas barragens e como o setor de energia repara estas transformações. $\mathrm{O}$ desafio constitui-se na transformação do esforço acadêmico a que este trabalho procura alcançar em um instrumento de contestação e transformação, para uma sociedade mais justa e sustentável. "A ética da justiça, da equidade e da cooperação devem se, sobrepor à lógica do mercado" (BERMANN, 2003, p.11).

Enquanto o sistema capitalista apodera-se do ambiente, as diferenças regionais adquirem maior relevância (Sigaud, 1988; Viana, 2003). De acordo com Scarpinella (1999), dentro da economia de um país, o conjunto das interações entre pessoas e empresas define a quantidade, a qualidade e os preços de bens e serviços que podem ser produzidos e distribuídos.

Como toda atividade econômica, a geração de energia elétrica demandada pela sociedade gera um custo, "o que é uma maneira sintética de dizer que consome capital, consome ou transforma (com degradação) recursos naturais "(SCARPINELLA, 1999, p.66).

A construção de barragens assim como outras obras de infraestrutura implicam tanto em uma reordenação territorial prévia quanto posterior a sua conclusão. A questão relacionada aos "custos sociais" nos empreendimentos hidrelétricos é um assunto que não é explorado pelo setor de energia. As definições que encontramos, foram surgindo durante a pesquisa sobre o tema dentro de inúmeras áreas do conhecimento.

Neste primeiro momento, optamos por apresentar o significado do termo "social", como ele é empregado de forma corrente na linguagem do dia a dia, também aparece em contextos mais formais, como os discursos públicos, políticos ou na área acadêmica. No entanto, é raro encontrar autores que deixem claro, o que realmente entendem por "social". Mas, quando se pretende utilizar o conceito de "social", como categoria central de análise, 
como é o caso desta dissertação, torna-se importante definir seu conteúdo, assim como seus limites.

No Brasil, a palavra "social" costuma aparecer sob duas conotações principais, porém muito diferentes, apesar do conceito ser o mesmo. A primeira, é aquela em que o "social” é usado para denominar uma série de fenômenos e situações dificultosas ao enquadramento de critérios mais técnicos, objetivos, racionais, profissionais, eficientes; sendo assim, lança-se para o social. Dessa forma, ele pode ser um adjetivo que se aplica especificamente a populações de baixa renda, como os "programas sociais" (MOURA, 2002).

Em outra conotação, cujo viés constitui o oposto do anterior, o termo "social" é aplicado à sociedade inteira, mas sob um enfoque demasiado genérico e homogêneo. É o caso dos indicadores sociais, como por exemplo, indicadores per capita.

Portanto, o conceito, quando entendido, não se refere a algo sem forma definida, conforme representada pelo dicionário, "social" é da sociedade ou algo relacionado a ela. Diz respeito especialmente às interações, relações e condições entre os integrantes da coletividade - pessoas e grupos.

As sociedades humanas existem em um determinado espaço, cuja formação social e configuração são específicas. Vivem o presente marcado pelo passado e projetado para o futuro, em um embate constante entre o que está dado e o que está sendo construído. "Portanto, a provisoriedade, o dinamismo e a especificidade são características fundamentais de qualquer questão social” (MOURA, 2002, p.12).

Neste estudo, quando tratamos do "social", entendemos que existe direcionamento da questão social para a identidade do indivíduo, pois o termo está diretamente relacionado com seres humanos que, por razões culturais, de classe, de faixa etária ou qualquer outro motivo, possuem uma identidade que sempre terá de ser respeitada. Esta identidade vem seguida de direitos preestabelecidos pelos dispositivos jurídicos quanto ao território e sua forma de agir.

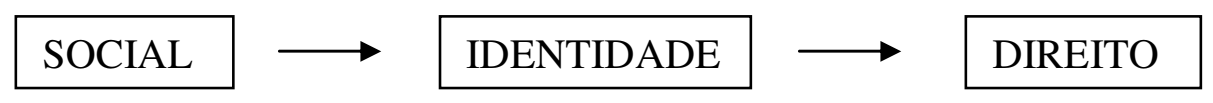

Os projetos de infraestrutura dependem fundamentalmente do meio ambiente, assim como da sociedade, cujas aspirações precisam ser atendidas, lembrando que sem a concordância da sociedade e violando seus interesses principais. O conceito do termo custo está fundamentado, como sendo os gastos relativos à produção de um bem ou serviço que se incorporam a quantia do bem ou serviço. 
[...] à instalação e ao funcionamento de obras deste tipo não são, em termos humanos, "espaços vazios", mas alojam diferentes segmentos sociais, torna-se indispensável a retirada compulsória das populações que historicamente vinham ocupando esses locais, dentre elas, no Brasil, mais comumente indígenas e camponeses (REIS ; BLOEMER, 2001, p.13).

Segundo Martínez (2007), existem três vertentes relacionadas ao meio ambiente e, consequentemente, à sociedade. A primeira, nomeada de "culto ao silvestre" - não ataca o crescimento econômico e coloca em discussão uma "ação de retaguarda", visa a preservar e manter o que resta sem a interferência do homem - a segunda "evangelho da ecoeficiência" preocupa-se com os efeitos do crescimento econômico, não só nas áreas de natureza intocadas, como também na economia industrial, agrícola e urbana, acredita no "desenvolvimento sustentável", na "modernização ecológica" e na boa "utilização dos recursos; para ela, Natureza é vista como Recursos Naturais; já a terceira é percebida como "ecologismo dos pobres" e pode também ser reconhecida como movimento de justiça ambiental, pois relaciona-se à economia ecológica que defende o crescimento econômico implica grandes transformações que se verificam no meio ambiente, chamando atenção para o "deslocamento geográfico" dos recursos e das áreas de descarte. Assim, não vê a natureza, como algo para se conservar, mas entende como fonte "material" de subsistência, seu objetivo maior é lutar contra os "impactos ambientais" que ameaçam os pobres.

As vezes a economia ecológica é concebida como uma tentativa de aplicar valores monetários aos recursos e serviços ambientais. No entanto é um campo de estudos transdisciplinar, estabelecido recentemente, que observa a economia, como um subsistema de um ecossistema físico global infinito (MARTINEZ, 2007). Desse modo, as pretensões de atribuir valores monetários aos serviços e as perdas ambientais, e as iniciativas no sentido de corrigir a contabilidade macroeconômica provêm da necessidade de penalizar os agressores do meio ambiente. Outras inspirações da economia ecológica podem ser encontradas na economia ambiental e nos recursos naturais, na ecologia humana, antropologia ecológica (ciências sociais) e na ecologia política.

Os economistas ecológicos trabalham com a relação entre os direitos de propriedade e de gestão dos recursos naturais, modelando as interações entre economia e meio ambiente, 
utilizando ferramentas de gestão como avaliação ambiental integrada ${ }^{12}$ e avaliações multicriteriais $^{13}$ para a tomada de decisões, propondo novos instrumentos de política ambiental.

As contribuições essenciais de uma visão ecológica da economia existiam muito antes do nascimento de uma economia ecológica consciente de si mesma. Essa demora é explicada pela rigidez das fronteiras existentes entre as ciências naturais e sociais (MARTÍNEZ, 2007, p.46).

Segundo Georgescu-Roegen apud Martinez (2007), o termo “desenvolvimento” está diretamente ligado às mudanças da estrutura econômica e social, enquanto "crescimento" possui uma conotação quanto à "expansão na escala da economia que, provavelmente, não tem condições de se sustentar ecologicamente" (Martinez, 2007, p.47). A partir desta proposta, a maioria dos economistas ecológicos aceita o termo "desenvolvimento sustentável”. Para Martínez (2007, p.47), prefere-se falar apenas em “sustentabilidade”.

A relação entre a floresta e os povos, assim como os direitos de propriedade, constitui uma área de interesse, tanto para a economia ecológica como para a ecologia política. (BERKES; FOLKE, 1998; MADHAVI JODHA, 2001 apud MARTINEZ, 2007).

${ }^{12}$ Avaliação Ambiental Integrada AAI: "é o processo interdisciplinar e social, ligando conhecimento e ação no contexto de decisão pública, para a identificação, análise e avaliação de todos os relevantes processos naturais e humanos e suas interações com atual e futuro estado da qualidade do meio ambiente e recursos nas apropriadas escalas de tempo e espaço, assim facilitando a definição e implementação de políticas e estratégias" (RHAMA, 2010).

${ }^{13}$ Metodologia Multicritério "é bastante interessante em problemas complexos, onde existam diversos tipos de decisões e cada um com vários pontos de vista que considera fundamentais no processo decisório, possuindo muitas vezes objetivos conflitantes e de difícil mensuração, além de, em muitos casos, utilizar variáveis de ordem qualitativa" (Wernke; Bornia, 2001, p.62) 
$\mathrm{Na}$ economia ecológica considera-se que a economia está inserida ou incrustada no ecossistema - ou para dizê-lo do modo mais preciso animada pela historicamente cambiante percepção social do ecossistema. A economia também está incrustada na estrutura de direitos de propriedade sobre os recursos e serviços ambientais, numa distribuição social do poder e da riqueza em estruturas de gênero, de classe social ou de casta, vinculado a economia ecológica com a economia política e com a ecologia política (MARTínEZ, 2007, p.47).

De um lado, a Ciência Econômica observa o sistema econômico como um sistema autossuficiente (Fluxo de mercadorias, Produção-empresas, Consumo-famílias), no qual são estipulados os preços dos bens e serviços, assim como os fatores de produção (matéria-prima). O que acaba gerando as "externalidades" - quando, em uma transação entre comprador e vendedor, afeta diretamente uma terceira parte, este efeito é chamado de externalidade. Se o impacto sobre o adverso for negativo, é chamado de externalidade negativa; se for benéfico, será chamado de externalidade positiva (MANKIW, 2005).

Os economistas ecológicos simpatizam com as intenções no sentido de "internalizar" as externalidades no sistema de preços, aceitando de bom grado as propostas para corrigir os preços através dos impostos (como tributos sobre o esgotamento do capital natural ou taxas incidindo sobre a contaminação). "Contudo negam a existência de um conjunto de "preços ecologicamente corretos (MARTínEZ, 2007, p.48).

Alguns otimistas acreditam que a distribuição torna-se mais equitativa com o crescimento econômico. Outros insistem que, pelo contrário, as disparidades também aumentam e que, de qualquer modo, ingressos monetários mais volumosos não implicam maior segurança, dado que a degradação ambiental e outros impactos sociais permanecem ocultos.

Na teoria econômica neoclássica o estudo do direcionamento dos recursos para a produção esteja analiticamente dissociado da distribuição da produção em distintas categorias sociais, na economia ecológica "distribuição" não significativa distribuição econômica, pois igualmente diz respeito à distribuição ecológica (MARTÍNEZ, 2007, p.49).

Torna-se evidente, portanto, que os padrões dominantes de produção e consumo aumentam as desigualdades sociais e ambientais, sendo assim "inicia-se o debate teórico e 
político para valorizar a natureza e internalizar as "externalidades socioambientais" ao sistema econômico" (LEFF, 2007, p.16).

Em termos econômicos, as externalidades podem permanecer como tais - isto é, fora da contabilidade dos resultados e do balanço da empresa - as decisões seriam diferentes caso tais passivos ambientais fossem incorporados à sua conta (inserindo algum valor econômico) como o exemplo observado por Martinez (2007):

[...] se uma fábrica de celulose no Brasil pode plantar eucaliptos ignorando a compensação pela perda de fertilidade e pode lançar os efluentes exercendo de fato direitos de propriedade sobre o rio ou o mar, suas decisões de produção são diferentes das que existiriam na hipótese de se ver obrigada a pagar por essas externalidades o caso tivesse que se confrontar com normas legais mais restritas sendo essas levadas a efeito à risca (MARTÍNEZ, 2007, p.52).

Em uma declaração da Comissão Mundial de Barragens apud Reis; Bloemer (2001), os efeitos negativos são indicados e afirmam que das 45 maiores represas em operação no mundo, incluindo as fornecedoras de energia elétrica, as de água para irrigação ultrapassam, na maioria dos casos, seus benefícios.

$\mathrm{Na}$ linguagem dos economistas, se todos exigirem compensação (internalização das externalidades) ou direitos territoriais, direitos humanos pela saúde e se obtiverem êxito, os custos serão diferentes às empresas envolvidas e as decisões da produção serão igualmente distintas.

Mas, entramos em uma discussão dentro da economia ecológica e da ecologia política que diz respeito às disputas sobre os sistemas de valoração. A distinção realizada pelos gregos entre "oikonomia" - é a arte do aprovisionamento material da casa familiar e "crematística" que é o estudo da formação dos preços de mercado para ganhar dinheiro.

Entre a verdadeira riqueza e os valores de uso, por um lado, e valores de troca, de outro, é uma distinção que hoje nos soa irrelevante porque o aproveitamento material parece dar-se, sobretudo, através de transações comerciais, existindo, portanto, uma aparente função entre a "crematística" e a "oikonomia (MARTÍNEZ, 2007, p. 53).

Como já foi mencionado, a economia ecológica não se compromete com um tipo de valor fixo, aceita a valorização monetária e outros tipos de avaliações, como as físicas e sociais. A valorização é realizada dentro do cotidiano das famílias, como também os danos 
sociais e ambientais não compensados. Por isso, a economia ecológica aproxima-se mais da "oikonomia".

Entende-se que o padrão de uso dos recursos naturais depende das relações de poder mutáveis e da distribuição de renda, entramos no campo da ecologia política, suas raízes estão na geografia e na antropologia, sendo definida pelos estudiosos, como referente aos conflitos ecológicos distributivos.

Segundo Kapp apud Martínez (2007), o crescimento econômico induz a ampliação dos impactos ambientais e dos conflitos, muitas vezes, fora da esfera do mercado. Existem inúmeros exemplos da incapacidade dos sistemas de preços ao indicar impactos ambientais ou abundam os exemplos de transferências bemtransferidas dos custos sociais.

Já Martin O’Connor apud Martínez (2007, p.58) assinala que o padrão de preços na economia seria diferente se incluísse os conflitos distributivos, ou seja, "é bem possível que um custo zero cobrado para extrair recursos ou para despejar resíduos indique abundância, mas apenas explicite uma relação histórica de poder”.

Portanto, para discutir a questão, é preciso interagir as diferentes áreas do conhecimento que tratam de diversos aspectos quanto à sustentabilidade.

\subsection{Custos Sociais nas Usinas Hidrelétricas}

O deslocamento envolve a perda quase total de controle de sua vida e, de modo geral, os processos de reassentamento fornecem informações insuficientes que permitam o desenvolvimento dessas populações.

As usinas hidrelétricas trazem consigo inúmeros efeitos negativos sobre a sociedade: a) o deslocamento compulsório da população residente na área inundada, b) a perda das terras cultiváveis e benfeitorias, c) pequenas e insuficientes indenizações pelas terras e benfeitorias e d) perda ou diminuição de peixes.

Como a grande maioria das comunidades ribeirinhas nas áreas de barragens é composta de pequenos agricultores, pescadores, caçadores e coletores, isso resulta na perda do acesso aos meios tradicionais de vida desses povos. Isso gera não só uma ruptura na economia local como, efetivamente, desloca as populações do acesso a uma série de recursos naturais, indispensáveis para sua sobrevivência (VIANA, 2003, p.37). 
Os problemas gerados pela exploração realizada pelos países industrializados, para atender suas demandas por matérias-primas e bens de consumo, importação massiva de petróleo, gás, alumínio, cobre, eucalipto, óleo de palma, camarão, ouro, soja transgênica trazem inúmeros problemas sociais e ambientais "que não são solucionados pelas políticas econômicas", o que acaba transformando a vida de inúmeras pessoas.

Nos últimos anos, um dos setores mais discutidos e polêmicos da economia é o de geração e distribuição de energia. Este se - tornou palco de grandes discussões socioambientais, em consequência das grandes transformações ocorridas nas áreas de instalação.

Leff (2007, p.33) aponta que o crescimento econômico deixa três dívidas, a primeira, dívida financeira: entendida, como sendo "(...) assumida ou não assumida, pagável ou não pagável, negociável, refinanciável" (LEFF, 2007, p.32). Esta afeta as condições das populações atingidas, cujos recursos são perdidos, introduzem as condições de desigualdade em que alguns possuem direitos e outros não possuem, degradando suas bases culturais e sociais, a dívida torna-se impagável na condição de que ela impõe suas "condições de exploração" é negociável, apoiada nas condições justas que são apresentadas.

Já a segunda dívida nomeada de dívida ecológica: citada por Leff (2007, p.32;35), como "incomensurável, mas capaz de ser revalorizada, internalizada, redistribuída". "O "jogo da dívida" não é uma questão moral sujeita a um cálculo estritamente econômico", o que está em jogo são questões que não possuem valor monetário, a paisagem, a relação com o local e a dívida ecológica em seu primeiro momento incomensurável e, consequentemente, impagável, tratam exatamente dos lugares onde enraizaram sua existência, estes são intraduzíveis em valores monetários. Contudo, as lutas pela legitimação dos direitos podem negociar uma compensação pelos danos sofridos como resultado da transformação ecológica ou aceitar uma distribuição dos benefícios, desta forma, as questões não são definidas com valores monetários, mas, poderá haver uma valorização do aspecto.

Por fim, a terceira dívida, é a dívida da razão, definida por Leff como: "abre o caminho do dessujeitamento, da ressignificação, da construção de um desenvolvimento alternativo, fundado em uma nova racionalidade produtiva, ou seja, "racionalidade ambiental". Contudo, satisfeitas as demandas e reivindicações restam seus devedores sujeitos à mesma razão, a repartição dos custos e benefícios, citados pela justiça e equidade. (LEFF, 2007, p.32;39). O crescimento econômico leva a pensar em uma nova condição de desenvolvimento. Se pararmos para pensar, faremos do nosso planeta uma grande lata de 
lixo, cujo o ciclo de consumo e descarte não tem fim. É preciso pensar em um modelo de desenvolvimento sustentável com princípios éticos, valores culturais e sociais.

$\mathrm{O}$ atual modelo de geração de energia que vem sendo implantado, acarreta uma superexploração da natureza, a homogeneização de culturas, subjugando saberes e degradando a qualidade de vida das minorias (LEFF, 2007, p.40).

Atualmente, os devedores destas dívidas pedem para escapar delas e não se responsabilizam pelos danos causados, quando o fazem não existe nenhuma padronização ou exigência mínima, o que acaba acontecendo de qualquer forma.

A ciência não oferece critérios para avaliar os conflitos distributivos que, inicialmente, não podem se firmar "racionalidade econômica" ou "ecológica", que não podem ser livres da política. Como indica Martínez (2007), o enfrentamento entre economia e ecologia não pode ser resolvido mediante "piedosas ladainhas", como as referentes a "internalizar as externalidades".

As estruturas sociais e a utilização do meio ambiente estão entrelaçadas de muitas formas. As comunidades têm desenvolvido organizações, visando a resistir às transformações sociais e ambientais decorrentes da privatização e da estatização de alguns departamentos. Com base, temos a luta do Movimento dos Atingidos por Barragens que vem desenvolvendo seu papel de resistência e luta para defender seus direitos.

A proposta de "custo social" nos empreendimentos hidrelétricos vem ao encontro do objetivo da ecologia política, que pede para incluir na contabilização do investimento inicial os empreendimentos hidrelétricos as condições sociais da população que terá uma transformação econômica, social e cultural, considerando os padrões mínimos para a dignidade de sobrevivência como: acesso à saúde, água potável, escolas, renda, direito de ir e vir.

A ecologia política estuda os conflitos ecológicos distributivos. Por distribuição ecológica são entendidos os padrões sociais, espaciais e temporais de acesso aos benefícios obtidos dos recursos naturais e aos serviços proporcionados pelo ambiente como um sistema de suporte de vida. Os determinantes da distribuição ecológica são em alguns casos naturais, como o clima, topografia, padrões pluviométricos, jazidas de minerais e a qualidade do solo. (...), no entanto são claramente sociais, culturais, econômicos, políticos e tecnológicos (MARTÍNEZ, 2007, p. 113).

Os economistas disfarçam os conflitos distributivos fazendo uso de palavras, como "externalidades" e "falhas de mercado", ou seja, os problemas são deslocados, os custos 
sociais transferidos de responsabilidade e nunca assumidos. Os custos são assumidos pelos menos favorecidos que precisam arcar com toda sua reestruturação social e produtiva.

O questionamento fundamental desta discussão é saber por bases numéricas quais são os sistemas de valoração, os "custos sociais" que serão traduzidos (MARTíNEZ, 2007, p. 114). Existem questões como a perda dos lugares sagrados, cemitérios, relação com a terra, às quais a contabilização não se aplica, e não são algo passível de valoração.

Martinez (2007) observa que se trata da "tragédia dos comuns" escrita por Hardin em 1968. Assim, o autor apresenta que a melhor solução para as áreas de acesso "comum", antes de entrar em degradação seria a "privatização". Assim, acredita quando o ambiente não possui proprietário, as famílias transferem os custos ambientais a toda sociedade. Mas Martinez aborda Hardin citando que:

deveria ter advertido a respeito da existência de uma assimetria entre custos e rendas, ou seja, o lucro está no presente e os custos localizam-se no futuro, como seria o caso, por exemplo, dos custos da não-disponibilidade futura da exploração (MARTÍNEZ ALIER, 2007, p. 120).

No Brasil, nas antigas áreas comuns que se transformaram em Áreas de Proteção Ambiental (APA) pelo Estado, não se consegue distinguir a lógica comercial da lógica sustentável utilizada pelas comunidades extrativistas, muitas vezes, as comunidades não podem ser utilizadas da forma como estavam acostumadas. Isso acarreta uma transformação local à extração de recursos, pela qual estas comunidades sobreviviam.

Geralmente as áreas destinadas à construção de barragens são habitadas por pessoas com baixo poder aquisitivo, que vivem de modo sustentável pela pesca e agricultura, além disso, muitas vezes, vendem o excedente aos povoados maiores ou trocam por alguma mercadoria de interesse.

Nessas áreas, a construção de barragens pressupõe a perda do sustento das pessoas que habitam e vivem no dia a dia dos produtos ofertados pela própria natureza, além de perder outras funções como a questão da vizinhança, as relações com a terra.

Goldemberg; Villanueva (2003) referem que muitos caracterizam as indústrias como fonte de energia. Assim, algo para ser sustentável deve beneficiar todos, o que não acontece com a construção de usinas hidrelétricas. Trata-se de uma "indústria não sustentável”, como 
exemplo a indústria de carcinicultura que se prolifera, e a cada lugar que passa, acaba deixando para traz "paisagens desoladas e pessoas desamparadas" (MARTINEZ, 2007).

Segundo Martinez (2007, p. 123), "trata-se de igual modo de um comércio desigual em função da transferência dos custos ambientais e sociais para as áreas das quais procede a produção".

Martínez (2007) propõe que as diferentes dimensões encontradas poderiam ser incorporadas à análise de investimento, às alternativas e aos critérios mais relevantes que poderiam surgir da intenção entre a população afetada e os especialistas externos - pessoas imparciais ao projeto. A cada alternativa, seria oferecido um valor em quantidade e qualidade, acatando todos os critérios. Um desses critérios também poderia incluir uma análise financeira ou, até mesmo, uma análise de custo-benefício com um dos critérios, sem incorrer em uma contabilidade repetida, pois os demais critérios seriam valorados no âmbito das suas próprias escalas físicas ou sociais.

A tarefa para viabilizar o local a ser construído o empreendimento, "vem sendo assumida, por força de lei, pelos empreendedores dessas obras” (REIS ; BLOEMER, 2001). Segundo Lemos (1999), nesse processo, as comunidades assumem um significado particular para o capital privado que as transforma em obstáculos à apropriação territorial pelo mesmo, devendo ser removidas para o cumprimento do "desenvolvimento regional". Desta forma, grandes empreendimentos acabam por gerar uma grande transformação social contraída e baseada nos custos sociais nos valores de financiamento e orçamento das obras. Assim, "o ocultamento dos custos sócio-ambientais que uma vez considerados e internalizados poderiam inviabilizar a competitividade dos empreendimentos" (LEMOS, 1999, p.3 apud ZHOURI, 2004).

Historicamente, o deslocamento forçado ocasionado pelos empreendimentos hidrelétricos deixou na pobreza milhares de pessoas afetadas pelos projetos. Como norma, depois da relocalização, as pessoas deslocadas não conseguem recuperar o nível de vida de que desfrutavam antes. A desterritorialização, como inverso da territorialização, é produzida no processo de desapropriação do espaço social, tanto do ponto de vista concreto como simbólico. Seu resultado é a multiplicação dos aglomerados de exclusão.

Atualmente, os custos sociais são medidos e pautados pelas quantidades que são disponibilizados pelas empresas e por seus técnicos que não vivenciam o dia a dia da comunidade e que não consultam seus proprietários. Em princípio, estes custos sociais nos 
reassentamentos seriam todos investimentos necessários para manter de forma adequada as bases de reprodução de uma determinada população atingida pela barragem. O principal objetivo é explicar e avaliar o papel dos empreendedores na reconstrução do relacionamento social, por meio de recursos financeiros necessários.

Segundo Rofman; Simone (1988) apud Vainer; Araujo (1992), os grandes projetos devem considerar as realidades "locais/regionais", a fim de contemplar suas reais necessidades.

Em que consiste a base fundamental das metodologias que seguem o citado enfoque reducionista realista? Em geral, consagra-se a calcular - quando se trata de estimar o impacto ambiental, social ou econômico na região - os custos e benefícios quantificáveis associados à implantação do projeto. Se a relação benefício-custo, do ponto de vista quantitativo, resulta altamente positiva, isto vem apoiar a argumentação favorável à realização ou financiamento da obra (...) na maioria das avaliações de projetos de investimento somente se leva em consideração a rentabilidade do capital incorporado mediante técnicas e critérios exclusivamente contábeis (ROFMAN ; SIMONE, 1988, p.5 apud VAINER ; ARAUJO, 1992, p.40).

O grande problema apontado por Rofman; Simone (1988); é a falta de um planejamento mais profundo, com mais detalhes, nos quais os aspectos do lugar deveriam ser mais relevantes para se julgar o mérito do projeto.

A natureza e lógica dos grandes aproveitamentos hidrelétricos não deixam dúvidas: trata-se de explorar determinados recursos naturais e espaços, mobilizar certos territórios para uma finalidade específica produção de eletricidade. Todo o que contraria ou escapa a esse fim aparece como obstáculo e surge no cronograma financeiro, sob a rubrica custos. Nestes termos, não espanta que sejam vistos como obstáculos tanto a população que ocupa as áreas a serem inundadas, como os usos da água para feitos por essa população - e, de maneira geral, todas as atividades econômicas e sociais que preexistam ao projeto (POSSE, 1988, p.36 apud VAINER ; ARAUJO, 1992, p.41).

Frente à necessidade de uma metodologia que contemple "um exame a partir do regional" (VAINER, ARAUJO, 1992, p.42. Rofman; Simone (1988) defendem a inserção dos interesses regionais no processo de realização do investimento, ou seja, "estabelecimento de 
formas de negociação" no qual o empreendedor forneceria informações importantes sobre o projeto, para que as partes atingidas pudessem avaliar melhor seus interesses.

[...] mesmo aqueles que têm defendido o "planejamento participativo" (para usar uma expressão muito em voga) estão conscientes dos obstáculos com que se defronta um modelo de decisão desta natureza, se o que se pretende garantir um real equilíbrio entre os diferentes interesses chamados a uma eventual mesa de negociação. Em primeiro lugar, porque, como já foi observado, os parceiros em volta da mesa detêm e expressam uma massa de poder - econômico e político absolutamente desproporcional. Em segundo lugar, porque enquanto de um lado o empreendedor (ou o setor do poder central envolvido) apresenta uma total unidade de objetivos e interesses - realizar o empreendimento ao custo mínimo -, de outro se encontram-se forças regionais que são heterogêneas - se é que expressam a complexidade da sociedade regional" como via de regra (VAINER ; ARAUJO, 1992, p.44).

Contudo a realocação pode gerar grandes transtornos à vida das pessoas afetadas, como: empobrecimento, danos ambientais graves, quebra da rede de apoio social, a menos que medidas adequadas sejam devidamente planejadas e implementadas. Estas devem ter como meta maior garantir a recomposição da qualidade de vida das pessoas afetadas pelo empreendimento. Vale ressaltar que o desejável é que a relocação da população proporcione uma real melhoria de vida às famílias afetadas.

Temos que atuar de uma maneira que a pobreza seja aliviada, nosso meio ambiente protegido e a justiça social ampliada, os Direitos Humanos reforçados. A injustiça social pode destruir os avanços econômicos e políticos (CERNEA, McDOWELL, 2000, p.46).

Em decorrência dos deslocamentos e da falta de uma política de compensação, a maioria da população foi para a periferia dos grandes centros regionais, aumentando, assim, o índice de pobreza e violência. Em parte, esses projetos são necessários, porque melhoram a qualidade de vida da população, levam ao "desenvolvimento". Em contrapartida, a vida de inúmeras pessoas é "sacrificada", restringindo os direitos dessa população, que são deixados 
de lado, de maneira que as populações afetadas estejam em condições piores que antes do deslocamento.

Isto traz sérias consequências em relação à Justiça Social e à Equidade que, em princípio, deveriam estar voltadas "às populações menos favorecidas", mas têm se convertido em uma arbitrária exclusão, resultando em uma distribuição equivocada dos custos e dos benefícios do desenvolvimento, uma vez que alguns povos ganham com o desenvolvimento e outros suportam seus custos.

Assim, um dos efeitos mais preocupantes nos deslocamentos involuntários é o empobrecimento.

Em diversos países, ocorre a falta de Justiça Social seguida de grandiosas perdas materiais, culturais, conflitos políticos que podem citados como exclusão de forma física de um território geográfico, econômico e social.

Esses deslocamentos deixam evidente o aumento da pobreza e a violência que apareceu como um desafio, para que sejam criadas medidas preventivas para reconstrução. Com certeza, podemos afirmar que inserindo e cumprindo políticas adequadas de maneira mais efetiva, é possível proteger os direitos civis das populações deslocadas. Dependendo do caso, existem maneiras de evitar o deslocamento involuntário ou mitigá-los. Os casos propostos pelos empreendedores, os deslocamentos não têm sido inteiramente justificados.

Sendo assim, de acordo com a realidade, na maioria dos empreendimentos hidrelétricos, os custos sociais não tem sido objeto de previsões. Ademais, não podemos ignorar os custos sociais causados pela construção de usinas hidrelétricas, centenas de pessoas, em sua maioria, lavradores, indígenas, ribeirinhos, pescadores acabam sendo expulsos de suas terras. As "supostas" indenizações arrastam-se por anos até serem pagas e, muitas vezes, não correspondem a quantia justa das terras desapropriadas.

O local onde se implanta um grande empreendimento hidrelétrico, para além de um cenário de "disputa" por recursos naturais, frequentemente expressa conflitos de conhecimentos, de entendimentos sobre o bem-estar ,como também de direitos, aflorados pelo confronto intercultural, mas, ao mesmo tempo, abafados pela balança desequilibrada de poder, produzida pelas tão indesejáveis desigualdades sociais e produtora delas.

A expansão desses projetos em nome do "progresso" está se tornando cada vez mais uma "ameaça" à região de implantação gerando, assim, grandes conflitos. Os denominados projetos de desenvolvimento que subestimam ou não consideram os custos sociais do local de 
implantação que estão predestinados ao fracasso, pois de acordo com o discurso político, o objetivo desses projetos é o bem estar do povo.

Portanto, quando eles deixam à margem milhares de pessoas, perde-se o objetivo principal, ou seja, da mesma forma, estes mesmos projetos quando ignoram a diversidade cultural existente em suas áreas de influência, ainda que a mesma não seja beneficiária quanto a seus objetivos, não apenas estão reproduzindo a desigualdade, mas, com certeza, estão também favorecendo seu pleno florescimento.

Percebe-se uma ação do Estado amenizando as diferenças, uma vez que falta assistência adequada aos atingidos, o que torna as populações deslocadas uma ameaça ao desenvolvimento econômico do País, pois com a relocação desordenada proliferam as favelas e aumentam as redes de contribuições assistencialistas por parte do Estado.

O Setor de energia, com o Estado, tenta buscar soluções mais adequadas e justas para os grupos sociais, analisando, assim, qual a melhor forma de reconstrução do novo espaço e suas implicações, bem como a retomada das atividades produtivas, levando em conta a condição da infraestrutura (construção das casas, escolas, postos de saúde, postos telefônicos), a recriação das "redes sociais" e a retomada do processo produtivo.

Os projetos de reassentamento, se forem incorporados ao valor inicial do investimento e realizados de modo adequado, de acordo com os direitos dos povos e comunidades que habitam os espaços destinados à construção das usinas, podem evitar inúmeras dificuldades, desafios e as frustrações vivenciadas por quem já passou por esse processo.

A perda material imposta gera um "custo social" que necessita ser considerado pela inserção regional dos interesses da população, não apenas do "planejamento participativo" que acabou-se tornando algo apenas formal, nos quais os interesses são impostos por meio de ameaças. Desse modo, torna-se preciso uma nova visão para o reconhecimento e desenvolvimento local das populações atingidas, respeitando-as, para que seja possível a reconstrução de sua identidade e de sua cidadania. 


\section{CAPÍTULO II - CARACTERIZAÇÃo DA ÁREA DE ESTUDO}

As terras adquiridas para o reassentamento não comportam todas as famílias das comunidades, desmembrando os grupos, com fortes laços de vizinhança e parentesco, que levaram dezenas de anos para se constituírem. Existem grupos que foram desmembrando com mais de 10 subgrupos, distantes em alguns casos até $50 \mathrm{~km}$ um do outro (Panfleto de conscientização, ONG CAMPO VALE).

O presente capítulo traz a abordagem do sistema Estadual de Meio Ambiente de Minas Gerais, Estado onde acontece o estudo de caso. Apresenta um breve relato a respeito da história da região, para demonstrar algumas atividades políticas, culturais e econômicas, bem como suas consequências na formação ocupacional do espaço regional do Vale do Jequitinhonha, assim como o processo de licenciamento da usina.

Os governos possuem muitas propostas salvadoras que prometem resgatar aquela gente da miséria em direção ao futuro de redenção e do "progresso". Uma das promessas, surgidas, na segunda metade 1980, era a construção de várias barragens para a geração de energia e a perenização de rios (RIBEIRO, 2008, p.85).

\subsection{Estrutura do Sistema Estadual de Meio Ambiente de Minas Gerais}

A construção de usinas hidrelétricas está regulada pela legislação brasileira. O Ministério de Minas e Energia (MME) é responsável pelos estudos do potencial hidrelétrico dos rios brasileiros. Baseados nesses levantamentos, é feita uma análise de toda a bacia hidrográfica referente à exploração do empreendimento. Sendo assim, os interessados em explorar o potencial energético de uma bacia precisam entrar com o requerimento de Licença Prévia para iniciar os estudos de viabilidade.

Segundo o Instituto Mineiro de Gestão das Águas (2008), Minas Gerais foi o Estado pioneiro na implementação de políticas de gestão dos recursos naturais. Em 2007, houve a descentralização do Sistema Ambiental, com a criação e implantação de Unidades Regionais Colegiadas (URCs) do Copam, que têm apoio técnico e administrativo das Superintendências Regionais de Meio Ambiente e Desenvolvimento Sustentável (SUPRAMS). Em dezembro de 2007, o Decreto no 44.667 reorganizou o Conselho, fortalecendo suas Unidades Regionais e estabelecendo nova estrutura para câmaras temáticas e grupos de trabalho. Além disso, recentemente foram criados duas novas URCs: a do Rio Paraopeba e do Rio das Velhas, que 
atendem aos municípios que fazem parte de tais bacias hidrográficas. Existem ainda outras oito URCs: Norte de Minas, Jequitinhonha, Leste Mineiro, Zona da Mata, Sul de Minas, Alto São Francisco, Triângulo Mineiro e Alto Paranaíba, Noroeste de Minas.

A questão de regularização ambiental é um instrumento do Sistema Estadual do Meio Ambiente e Recursos Hídricos (SISEMA), a fim de garantir o uso sustentável dos recursos naturais. O processo prevê a emissão de Licenças Ambientais e de Autorizações Ambientais de Funcionamento (AAF), de acordo com o porte do empreendimento. Contudo, os empreendimentos considerados de maior impacto devem proceder com a regularização por meio do processo de licenciamento ambiental, com o requerimento das Licenças Prévias (LP), de Instalação (LI) e de Operação (LO).

O Sistema Estadual do Meio Ambiente e Recursos Hídricos (SISEMA) é formado pela Secretaria de Estado do Meio Ambiente e Desenvolvimento Sustentável (SEMAD), pelos Conselhos Estaduais de Política Ambiental (COPAM) e de Recursos Hídricos (CERH) e pelos órgãos vinculados: Fundação Estadual do Meio Ambiente (FEAM), responsável pela qualidade ambiental no Estado, o Instituto Estadual de Florestas (IEF), e até Instituto Mineiro de Gestão das Águas (IGAM).

\subsection{Localização geográfica do Vale do Jequitinhonha e suas características}

O Vale está localizado a Nordeste do Estado de Minas Gerais. A região é caracterizada pela predominância de unidades familiares na agricultura e "baixo dinamismo econômico e lavoura extrativista" (RIBEIRO, 2008), além da posse de terra pulverizada.

$\mathrm{O}$ autor citado relata que, antigamente os moradores do Vale falavam de um "tempo de fartura", uma época em que a região exportava produtos agrícolas por meio de um intenso trânsito comercial realizado pelos tropeiros. Nos últimos 100 anos, os lavradores do Jequitinhonha têm migrado tanto sazonal como definitivamente.

No final do século XIX, migravam para o trabalho nas lavouras de café, no Leste de Minas Gerais; em 1950, dirigiram-se à fronteira agrícola do Paraná e colheita de algodão no interior de São Paulo. No início de 1970, iam a Belo Horizonte e São Paulo, capital, para construção civil e, em 1980, às lavouras de corte de cana no interior São Paulo. Este fluxo ainda continua nos dias atuais. (GALIZONI; RIBEIRO 2004). 
O Vale é dividido em três regiões com administrações pertinentes a cada uma: Alto Jequitinhonha, Médio Jequitinhonha e Baixo Jequitinhonha. Em 1955, a primeira divisa intrarregional do Vale foi estabelecida, como medida estratégica de governabilidade.

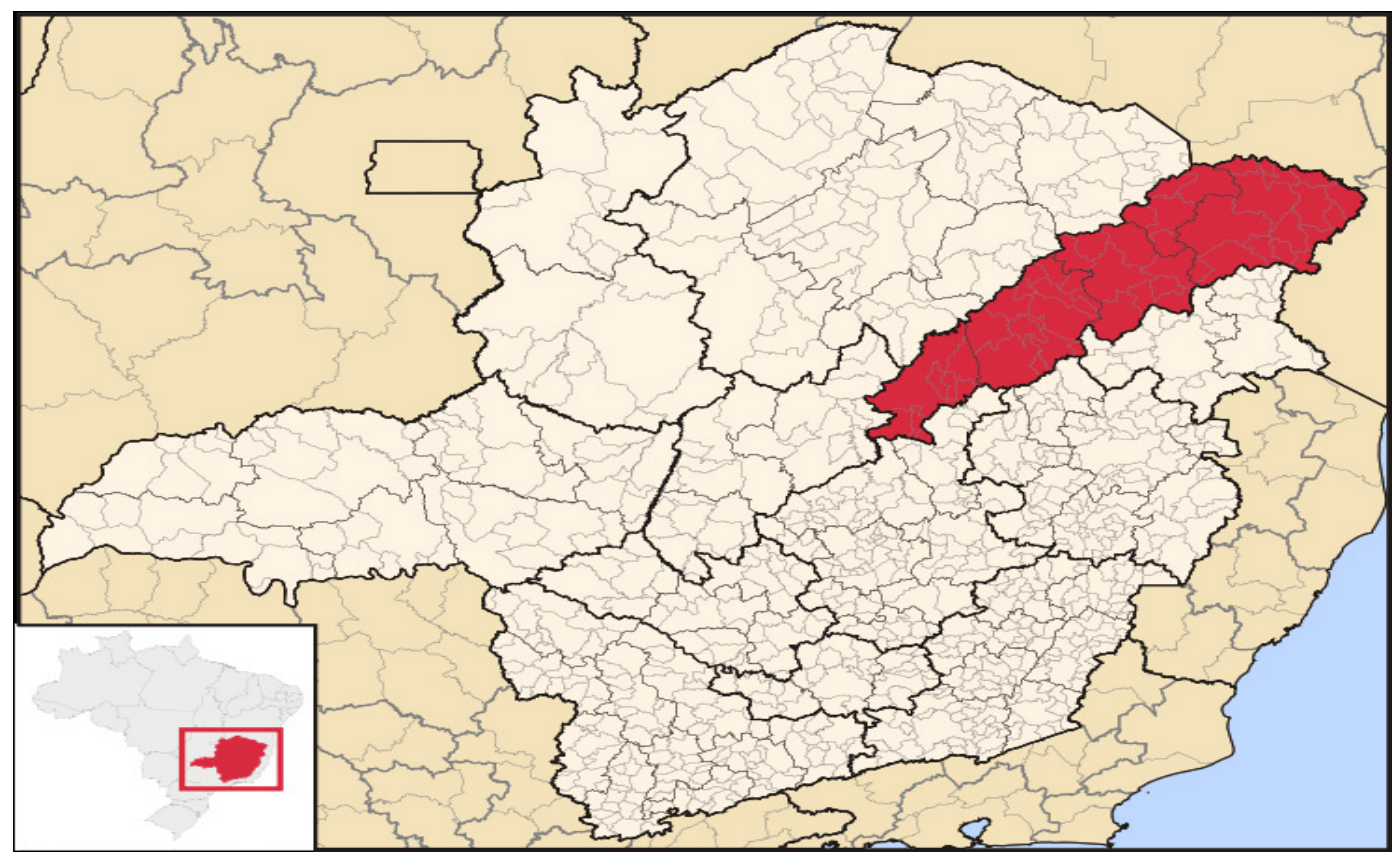

Figura 2. 1: Região do Vale do Jequitinhonha

Fonte: Extraído de: http://pt.wikipedia.org/wiki/Vale_do_Jequitinhonha. Acesso em 17/06/2008.

Uma das marcas da ocupação humana da região foi o ruralismo da paisagem desde o período colonial. Assim, a ocupação luso-brasileira da região iniciou-se a partir do garimpo de diamantes, realizado, sobretudo, na serra de Santo Antonio, perto do Rio Itacambiruçu. Nessa região, houve a presença de garimpeiros clandestinos que mineravam em um dos córregos afluentes do rio e na própria serra.

Em razão da decadência da mineração de diamantes, a região tomou o perfil econômico agropecuário que apresenta até hoje. Desse modo, tanto na atividade garimpeira como no plantio e criação, percebe-se que a ocupação humana vem aproveitando e interagindo com o aspecto natural do Alto Jequitinhonha. A região é caracterizada por serras, chapadas e vales dos rios. As chapadas estão no meio das áreas com grande extensão de terrenos planos e elevados pouco férteis e com poucas fontes de água (SANTOS, 2007).

No início do século XIX, as atividades de mineração de ouro, diamante e a exportação de algodão entram em declínio. Até os anos de 1970, a região era marcada pela expansão da pecuária e pela importação de grandes extensões de monocultura de eucalipto. 
Para Calixto; et. al. (2005), a adoção da monocultura de eucalipto na região do estudo é alvo de críticas pelas populações rurais e pelas organizações ambientalistas. No entanto, as empresas reflorestadoras justificam as transformações da atividade por gerar emprego e renda aos municípios onde estão instaladas e consideram que a atividade é a principal responsável pela ocupação da força de trabalho e geração de riqueza à região.

Há algumas décadas a população de parte significativa do Vale do Jequitinhonha foi roubada. Não por um roubo qualquer, de perda de um bem ou uma poupança, mas pela usurpação violenta de seus meios de subsistência e trabalho, de produção e reprodução da vida. Um grupo numeroso de trabalhadores rurais, que vivia do cultivo e da criação de gado para o consumo próprio, teve suas terras surrupidas pela estatal Acesita ${ }^{14}$ para a plantação de milhares e milhares de hectares de Eucalipto, matéria-prima do carvão utilizado por suas usina (MACHADO; FARRER, 2009, p.1).

Desse modo, observa-se que a geração de emprego é questionada, pois não resolveu os problemas da região: como desemprego e alta emigração sazonal. Assim, após 30 anos da implantação da política de incentivos ao reflorestamento, a região ainda é vista como "atrasada" em relação ao Estado de Minas Gerais: o Vale continua a ser chamado "Vale da Miséria" e "da morte". Continua a ser prioridade para o governo, sendo alvo de programas de transferência de renda e erradicação da fome e da pobreza (CALIXTO et. al., 2005). Na década de 1970 houve a criação de incentivos fiscais à atividade reflorestadora.

Desse modo, em razão da falta de empregos, desde a estagnação e isolamento da região do Vale do Jequitinhonha ${ }^{15}$ milhares de lavradores e lavradoras fazem e refazem o trajeto até outras regiões, espalhando-se pelo território brasileiro, como também aos países do exterior ${ }^{16}$.

Calixto et al. (2005) citam que o eucalipto foi a solução técnica para o reflorestamento energético, visto que a siderurgia era central para o desenvolvimento econômico do País, segundo a visão implantada no regime militar, pois servia de base às indústrias de bens de consumo duráveis que levariam para frente o desenvolvimento.

\footnotetext{
${ }^{14}$ Acesita é privatizada e, posteriormente vendida e transformada em Arcelor Mittal.

${ }^{15}$ Uma abordagem crítica dessa produção de conhecimento encontra-se em Ribeiro (2008).

${ }^{16}$ Fato relatado por pesquisadores do NEPAM/UNICAMP (2008) que existem inúmeros casos de
} migrantes para os países do México e EUA clandestinamente para trabalhar como pedreiros, jardineiros, babás e garçonetes. 
Assim, o argumento a favor do eucalipto era seu rápido crescimento - primeira colheita entre 7 anos, e um maior rendimento na produção de carvão (FARIA, 1971 apud CALIXTO; et al., 2005).

Segundo os autores citados, os argumentos técnicos, empresariais e governamentais para implantação do reflorestamento com eucalipto e pinus foram:

As reservas de matas nativas não seriam suficientes para atender à demanda de matéria-prima da indústria siderúrgica; o carvão do eucalipto mostrava-se de melhor rendimento que o nativo; o eucalipto fornecia lenha com menor período de tempo; e as espécies exóticas se regeneravam, até três vezes mais rápido que o cerrado (majoritariamente utilizado, após a extinção das reservas de mata atlântica) (CALIXTO et. al., 2005).

A política de incentivos fiscais ao reflorestamento concedia a pessoas físicas e jurídicas descontos de até $50 \%$ no imposto de renda, desde que esta quantia fosse usada nos projetos de reflorestamento próprios ou de terceiros. Esta medida animou os investidores, pois as pessoas jurídicas, antes de realizarem os projetos, tinham acesso a empréstimos para fazerem os investimentos

O Vale do Jequitinhonha foi definido como "distrito florestal" para integrá-lo ao padrão de crescimento econômico de Minas Gerais, com programas que buscaram acelerar "o incremento de renda e do emprego, através do incentivo, da coordenação e do planejamento para melhor aproveitamento da área" (IEF, 1975 apud CALIXTO et al, 2005, p.3).

No que se refere à agricultura do Alto Jequitinhonha, este se baseia no sistema de produção tradicional. Esta agricultura familiar pelas características ambientais e culturais é independente de recursos externos, e até relacionada às características do ambiente, como clima e tipo de solo que requer os trabalhadores e trabalhadoras nas atividades de preparo do solo e colheita.

Seus principais produtos são: milho, mandioca e cana de açúcar que, em parte, são consumidos pela família e, em parte, comercializados in natura nos mercados locais ou transformados pela indústria doméstica rural. Também se destacam produtos da fruticultura e horticultura.

A renda da agricultura familiar é complementada por programas de transferências e por aposentadorias que oferecem uma renda substancial à renda das famílias rurais. 
Quanto à herança da terra, Galizoni; Ribeiro (2004), relatam que se trata de decisões familiares e individuais feitas ao longo do tempo; assim, os filhos migram, mas não saem de uma vez, e sim, aos poucos vão experimentando as oportunidades, com a retaguarda da família, até que saem de vez, visto que a saída é inevitável, pois a terra é pouca para conter todos os familiares.

Assim, herança do migrante é relacionada a dois fatores:

\begin{abstract}
Alianças matrimoniais - "pois o casamento é muito importante para acesso à terra. Desse modo os casamentos definem a trajetórias dos membros da família; o segundo fato baseia-se nas viagens temporárias que os membros das famílias realizam, pois o dinheiro ganho em outras regiões garante o direito à terra, resolve as demandas para construir casa, fazer reformas e comprar gado" (GALIZONI; RIBEIRO, 2004).
\end{abstract}

A migração ocorre em grupo, vão para onde já se encontram parentes ou afins, reconstroem em outros lugares (rurais ou urbanos) suas famílias e, também, criam teias de solidariedade e apoio aos lavradores que precisam migrar. Trata-se de laços familiares, assim, quem migrar definitivamente recebe, pelo menos, uma vez por ano a visita de parentes. Também, retribuem a visita, participam de festas comunitárias e acolhem doentes em tratamento.

O casamento assume papel central na superação das distâncias geográficas e na conservação das relações sociais. Uma grande parte dos migrantes casa-se com pessoas de sua comunidade ou região.

No que se refere à mão de obra para trabalhos temporários em outras regiões é um processo comunitário e familiar; e a função do empreiteiro da mão de obra ou gato, que não é visto pelas famílias como explorador, e sim com admiração e respeito. È uma espécie de ligação nas relações de emprego entre fazendas e empresas (GALIZONI, 2000).

O gato tem por objetivo zelar pela sua turma, garantindo condições razoáveis de trabalho correndo risco de ser desertado. Entre o empreiteiro e as famílias dos lavradores, as relações são desiguais de trocas de favor, são solidificadas por laços de parentesco e compadrio. Muitos desses empreiteiros seguem carreiras políticas, são prefeitos, vereadores e vice-prefeitos (GALIZONI;RIBEIRO, 2004).

Desse modo, pode-se observar que casamento, herança e migração combinam-se e arranjam-se de forma que podem assegurar a reprodução do patrimônio e da família. 
Quanto ao padrão cultural de interação com o meio, que inclui a ocupação humana da região, as populações ribeirinhas do alto do Jequitinhonha estão entre as sociedades tradicionais; no qual o passado é cultuado e os símbolos são valorizados por conterem a experiência de gerações. Assim, a religiosidade popular é um dos padrões mais ricos na lida com o tempo e o espaço no alto Jequitinhonha.

O conjunto desses elementos-mecanismos de adaptação e transformação do meio, técnicas de plantio e de extração mineral, formas de vivência comunitária, forma de expressão religiosa, artística e simbólica, forma o patrimônio cultural das comunidades do alto Jequitinhonha. Os elementos materiais e imateriais de expressão dessa sociedade tradicional ganham, assim, a qualidade dos bens culturais (SANTOS, 2007, p.6).

È comum também atribuir à região uma imensa riqueza cultural que se resume em seu artesanato, folclore e em suas famosas festas religiosas, como foi mencionado acima. O Vale possui uma importância muito rica com a referência cultural e o orgulho sertanejo, o homem rural, valorizando todo um modo de vida da região.

\subsection{A UHE Irapé - Histórico do Processo de Licenciamento}

Os estudos de viabilidade foram realizados na década de 1960 por convênio do governo brasileiro com a multinacional canadense Cananbra (Engineering Consultant Limited) que identificou alguns pontos para construção de barragens. Estes estudos indicavam a possibilidade de implantação de 20 aproveitamentos hidrelétricos, de pequeno e médio porte, nos rios Jequitinhonha, Araçuaí, Itacarambiruçu e Vacaria (PCA, 2001).

Na década de 1980 a Enerconsult Engenharia Ltda foi contratada pela Cemig, para realizar a revisão e atualização dos trabalhos desenvolvidos anteriormente pela Canambra, resultando na possibilidade de implantação de 14 aproveitamentos hidrelétricos na referida bacia hidrográfica, incluindo os Estados de Minas Gerais e da Bahia.

Tais projetos de infraestrutura tinham como objetivo principal constituir uma região auto-suficiente em termos energéticos e de disponibilidade hídrica, fazendo com que indústrias e novos projetos se instalassem na região para reverter o cenário econômico.

Segundo Zucarelli (2006), das 14 barragens previstas para a região, apenas sete foram construídas. 
Em 1988, iniciaram-se os Estudos de Viabilidade da UHE de Irapé, com a elaboração de Impacto Ambiental - EIA e do Relatório de Impacto Ambiental - RIMA. Estes trabalhos foram concluídos em dezembro de 1993.

A CEMIG é o empreendedor responsável pela usina hidrelétrica de Irapé, que está localizada no rio Jequitinhonha, com uma barragem de 205 metros de altura, a mais elevada do Brasil. $\mathrm{O}$ empreendimento encontra-se entre os municípios de Berilo à margem direita e Grão Mogol à margem esquerda, com uma potência instalada de 360 MW. O alagamento resultante atingiu 47 comunidades ribeirinhas, 3.564 pessoas nos municípios de: Berilo, José Gonçalves de Minas, Leme do Prado, Turmalina, Grão Mogol, Cristália e Botumirim (TAC, 2002).

O início do processo de licenciamento ambiental da UHE Irapé deu-se em 14 de março de 1994, quando a Cemig encaminhou à Fundação Estadual do Meio Ambiente - FEAM, o requerimento de Licença Prévia - LP acompanhado pelo EIA\Rima do Projeto.

Em fevereiro de 1995, a CEMIG deixou de ter a concessão definitiva do aproveitamento energético de Irapé, em função da implantação em nível nacional da Lei Federal $\mathrm{n}^{\mathrm{o}}$. 8.987 de 13.02.95 ${ }^{17}$. Assim sendo, Irapé passou a ser objeto de uma futura Licitação Pública (que foi concretizada em dezembro de 1998).

Em junho de 1995, para não interromper o processo de licenciamento ambiental da UHE Irapé, o então Departamento Nacional de Águas e Energia Elétrica, DNAEE solicitou a Cemig a continuidade da condução do processo até a obtenção de Licença Prévia, o que foi concretizado.

Em abril de 1996, a FEAM solicitou à CEMIG informações complementares ao EIAIRIMA relativas aos aspectos socioeconômicos e, em maio, aquelas relativas aos temas Geologia e Recursos Minerais e, posteriormente, em (julho de 1996) as relativas ao tema FloralVegetação.

Em 12 de agosto de 1996, a CEMIG enviou à FEAM as informações complementares ao EIAIRIMA de Irapé, relativas aos aspectos socioeconômicos e, em 19 de setembro de 1996, o restante das informações complementares solicitadas pela FEAM.

\footnotetext{
${ }^{17}$ Dispõe sobre o regime de concessão e permissão da prestação de serviços públicos previsto no art.
} 175 da Constituição Federal e dá outras providências (BRASIL,1988. 
A Licença Prévia à UHE Irapé foi concedida pela Câmara de Bacias Hidrográficas do Conselho de Política Ambiental de Minas Gerais (CBH/COPAM), com 47 condicionantes estabelecidas no parecer técnico - jurídico da FEAM $^{18}$.

Em julho de 1998, a Agência Nacional de Energia Elétrrica - ANEEL, sucessora do Departamento Nacional de Águas e Energia Elétrica - DNAEE enviou à FEAM as exigências e Recomendações do Instituto do Patrimônio Histórico e Artístico Nacional - IPHAN e da Fundação Cultural Palmares - FCP que deverão compor o Plano de Controle Ambiental PCA.

No mesmo ano, a Companhia Energética de Minas Gerais - venceu a licitação pública para a outorga da Concessão de Uso e Bem Público para exploração do aproveitamento Hidrelétrico Irapé.

Em 1999, a equipe da Cemig buscou a contratação da Empresa de Assistência Técnica e Extensão Rural de Minas Gerais - EMATER, para realizar o trabalho de "Identificação das áreas potenciais para a implantação de projetos de Reassentamento da população a ser deslocada". O referido trabalho foi desenvolvido entre outubro de 1999 a fevereiro de 2000 (PCA, 2001). Em outubro de 2000, foram contratados os estudos ambientais para a elaboração do Plano de Controle Ambiental - PCA, em atendimento às condicionantes solicitadas pela FEAM, à época da concessão da LP. Estes estudos foram iniciados em janeiro de 2001, e o PCA consolidado em novembro do mesmo ano.

Conforme aponta Zucarelli (2006), o andamento do processo de licenciamento ambiental da Usina de Irapé, tinha múltiplos problemas que continuavam em evidência, inclusive, a dificuldade em se encontrar terras de qualidade para o reassentamento, a fim de cumprir uma das condicionantes do LP.

Estamos atrasados pelas dificuldades que nós estamos tendo em face de encontrar uma terra digna para os senhores. Nós estamos querendo comprar qualquer terra, se isso fosse possível, se isso fosse a política da empresa, nós teríamos adquirido qualquer terra, em qualquer situação. Mas não é este o caso (Moraes apud ZUCARELLI, 2006, p.78).

${ }^{18}$ Destaque da condicionante 2.3.10 que diz respeito ao plano de reassentamento das famílias, que iremos tratar a seguir. 
Uma das recomendações da FEAM era a participação das comunidades no Plano de Controle Ambiental (PCA), o que também se verificou.

De acordo com as denúncias, a participação dos atingidos na elaboração do PCA ficou restrita ao papel forçado de responder aos questionários aplicados pela empresa responsável pelo desenvolvimento do Plano de Controle Ambiental. (ZUCARELLI, 2006). A ONG Campo Vale com a Comissão de Atingidos pela barragem de Irapé, denunciaram o abuso com que a empresa contratada para elaboração do Plano praticou aos atingidos. Todos os problemas no processo de licenciamento da UHE de Irapé foram analisados por Zucarelli (2006). A exclusão da população de suas terras apresenta-se na forma de ameaça à capacidade de reprodução de seu modo de vida e de seus descendentes.

No final de 2001, após o pedido da Licença de Instalação, iniciou uma ampla articulação na política mineira, para dar prosseguimento ao licenciamento de Irapé. Nesse momento, o MPF assumiu a função de mediador entre os interesses atingidos e a CEMIG, Estado e a FEAM, tudo isso sem aprovação da comissão dos atingidos. A partir daí, o MPF começou sofrer pressão dos órgãos que solicitavam a proposta para Licenciamento.

[...] o MPF convidou os atingidos e perguntou se eles estavam dispostos a negociar. Ao mesmo tempo ele negociava nos bastidores com o Estado e com a Cemig, com a empresa. Ele aceitou. E, a gente é igual a marido traído, nos somos os últimos a saber. Mas, como a gente falou que ia negociar [...] No dia lá [reunião da Câmara Infraestrutura que aprovou a LI pra a UHE Irapé], quando o COPAM tirou essa carta da manga, falou que seria assim, a gente tava lá para isso mesmo. Na verdade, a gente sabiam então, que ia começar uma etapa de negociação. A gente confiava na figura do Procurador como mediador. Então, a partir daí - essa licença foi concedida em abril de 2002 - então, a partir daí, começou outro trabalho mesmo, de costurar as reivindicações etc. e tal e passar pra a etapa de negociação mesmo (Entrevista concedidada por Richarles Caetano Rios, advogado ONG Campo Vale, 12.04.2005 apud ZUCARELLI, 2006, p.87).

Mesmo não tendo cumprido as determinações legais exigidas no processo de licenciamento ambiental, a empresa e o governo do Estado de Minas Gerais buscavam, por meio da política, a concessão da licença de instalação e a respectiva postergação das condicionantes.

Com todas as advertências do parecer técnico da FEAM que recomendava à inviabilidade ambiental do empreendimento, e com toda a pressão de diversas entidades, a 
CIF/COPAM manteve a decisão e concedeu a Licença de Instalação em 26.04.2002. Que foi condicionada à assinatura de um Termo de Ajustamento de Conduta (TAC) com a intermediação do MPF, FEAM, Comissão de Atingidos e IBAMA.

A estratégia anterior descrita para ter o MPF como mediador foi o início para a concessão da Licença de Instalação. Portanto, a validade da LI ficaria atrelada à assinatura do "acordo" entre as partes.

Mas, segundo Zucarelli (2006, p.107), "a garantia de cumprimento das exigências ambientais legais, mediante posicionamento contrário à concessão de licenças, conforme prevê a legislação ambiental, foi postergada mais uma vez para outra etapa, a última do processo de licenciamento".

Em abril de 2002, iniciaram-se as obras de engenharia da Usina de Irapé (desvio do rio, concretagem das estruturas principais - tomada d'água, casa de força e vertedouro).

Em 2004, o enchimento do reservatório foi iniciado, mas foi atrasado em razão do processo de reassentamento das famílias que residiam na área inundável, visto que a Cemig ainda não definira o local dos reassentamentos (SANTOS, 2007).

Em dezembro de 2005 a Cemig obteve a Licença de Operação da Usina, antes mesmo de realizar todas as condicionantes citadas nas Licenças Prévia e de Instalação.

\subsection{Características técnicas e área de abrangência}

Pautada nos dados fornecidos pelo empreendedor, foi possível a construção de uma ficha técnica do empreendimento, contendo as principais informações sobre a usina de Irapé. O consórcio construtor da UHE de Irapé foi formado pelas empresas Andrade Gutierrez, Norberto Oderbrecht, Ivaí Engenharia de Obras e Hochtief do Brasil, sendo a responsabilidade do fornecimento e montagem de material eletromecânico da empresa Voith Siemens.

A seguir, é apresentada a ficha técnica com uma compilação de dados feita, após a análise da ficha original apresentada no Plano de Controle Ambiental (PCA, 2001). Os dados para elaboração da ficha foram selecionados em função da área de estudo, como localização do empreendimento, área de abrangência do reservatório, tamanho da barragem, potência instalada, número de geradores, cronograma das fases de construção e o efetivo da mão de obra para a construção da obra. 
Os dados que não foram inseridos nesta compilação e que constam na ficha técnica original, são dados hidrometeorológicos, dados sobre escavação, dimensões do desvio, vertedouro, dimensões das comportas tomadas d'água e túneis de adução.

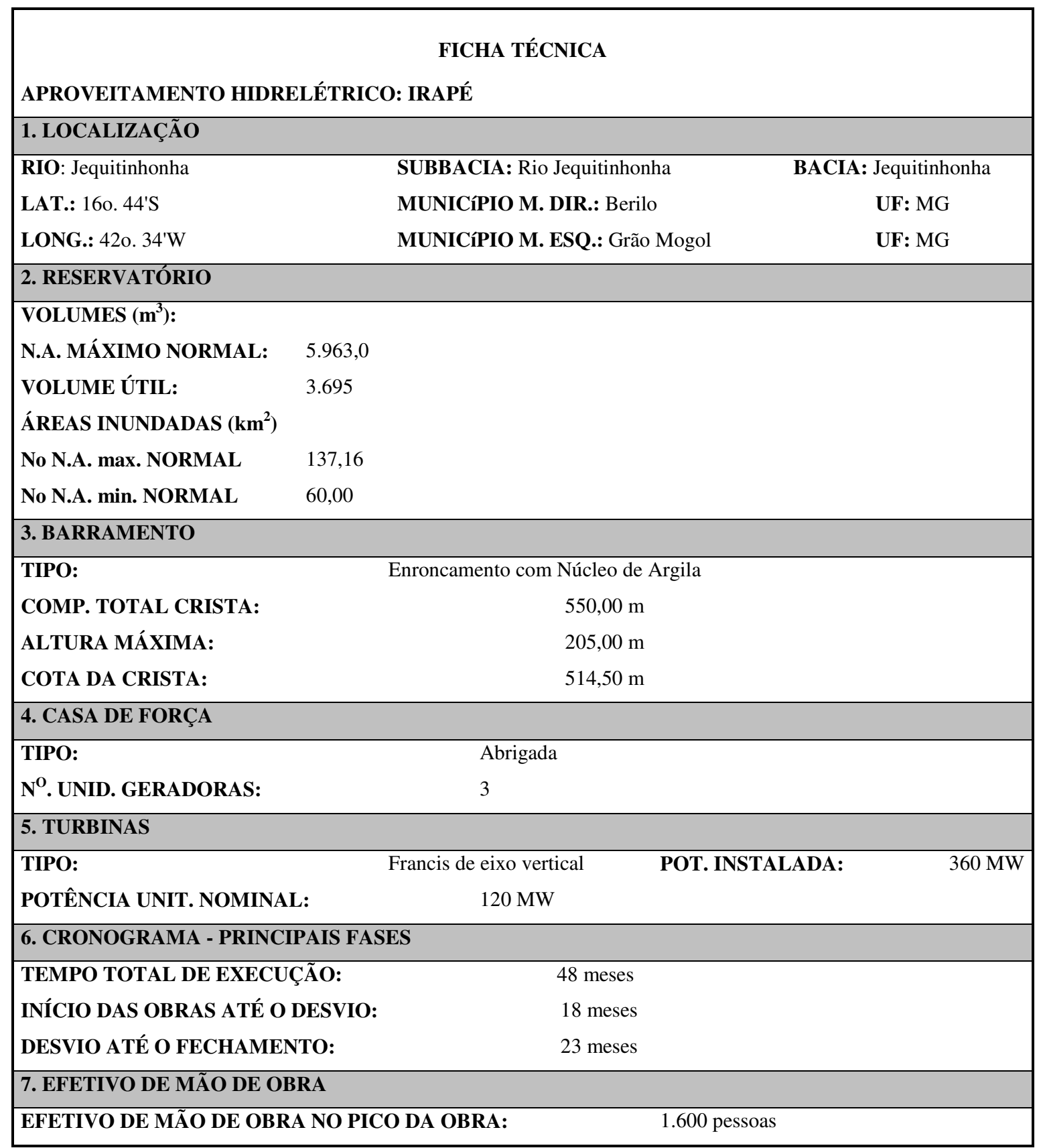

Figura 2. 2: Ficha Técnica da UHE de Irapé

Fonte: Arquivo da pesquisadora, com base na Ficha Técnica do empreendedor PCA - CEMIG, 2001.

O item de número 7: Cronograma das principais fases evidencia a forma com que o empreendedor trata as questões da obra civil. Em nenhum momento, a ficha técnica original mencionou questões ou a data prevista para deslocamento da população da área de abrangência do reservatório. 
O alagamento resultante abrange núcleos urbanos e áreas em uma extensão de $115 \mathrm{~km}$ do Rio Jequitinhonha e de $50 \mathrm{~km}$ do Rio Itacambiriçu, um de seus afluentes. A usina hidrelétrica atingiu sete municípios, entre eles: Grão Mogol, Cristália e Botumirim à margem esquerda e Berilo, José Gonçalves de Minas, Leme do Prado e Turmalina à margem direita do Rio Jequitinhonha. Como demonstrado na Ficha Técnica, a área submersa pelo reservatório foi de $137,16 \mathrm{~km}^{2}$.

A seguir, demonstraremos três fases na construção da UHE de Irapé. A primeira, demonstra o local exato para a construção da barragem e as outras duas sequências, demonstram os momentos durante a construção da barragem.

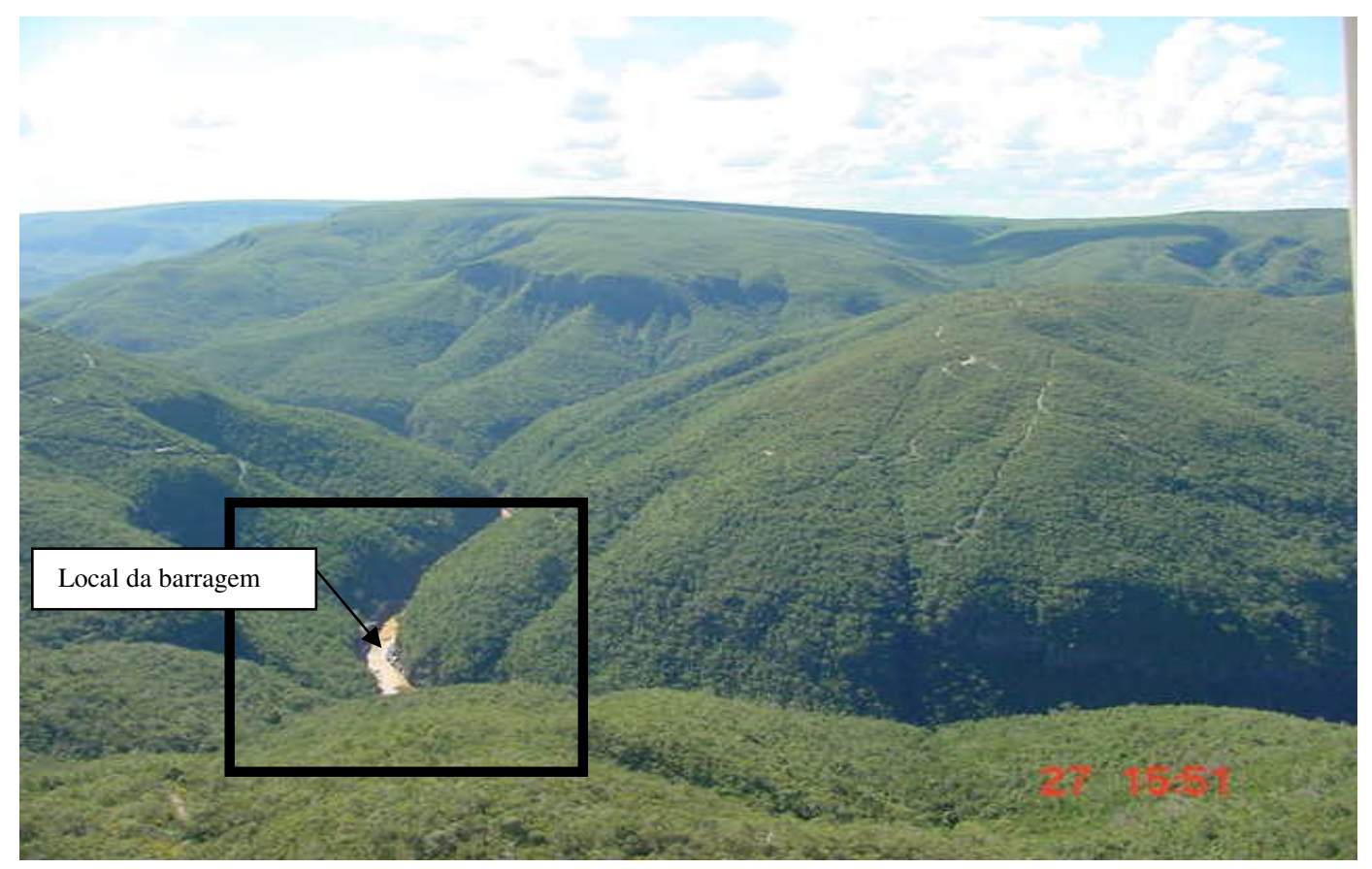

Figura 2. 3: Área de construção da Usina de Irapé Fonte: CEMIG, apresentação PUC Minas Gerais, (2006). 


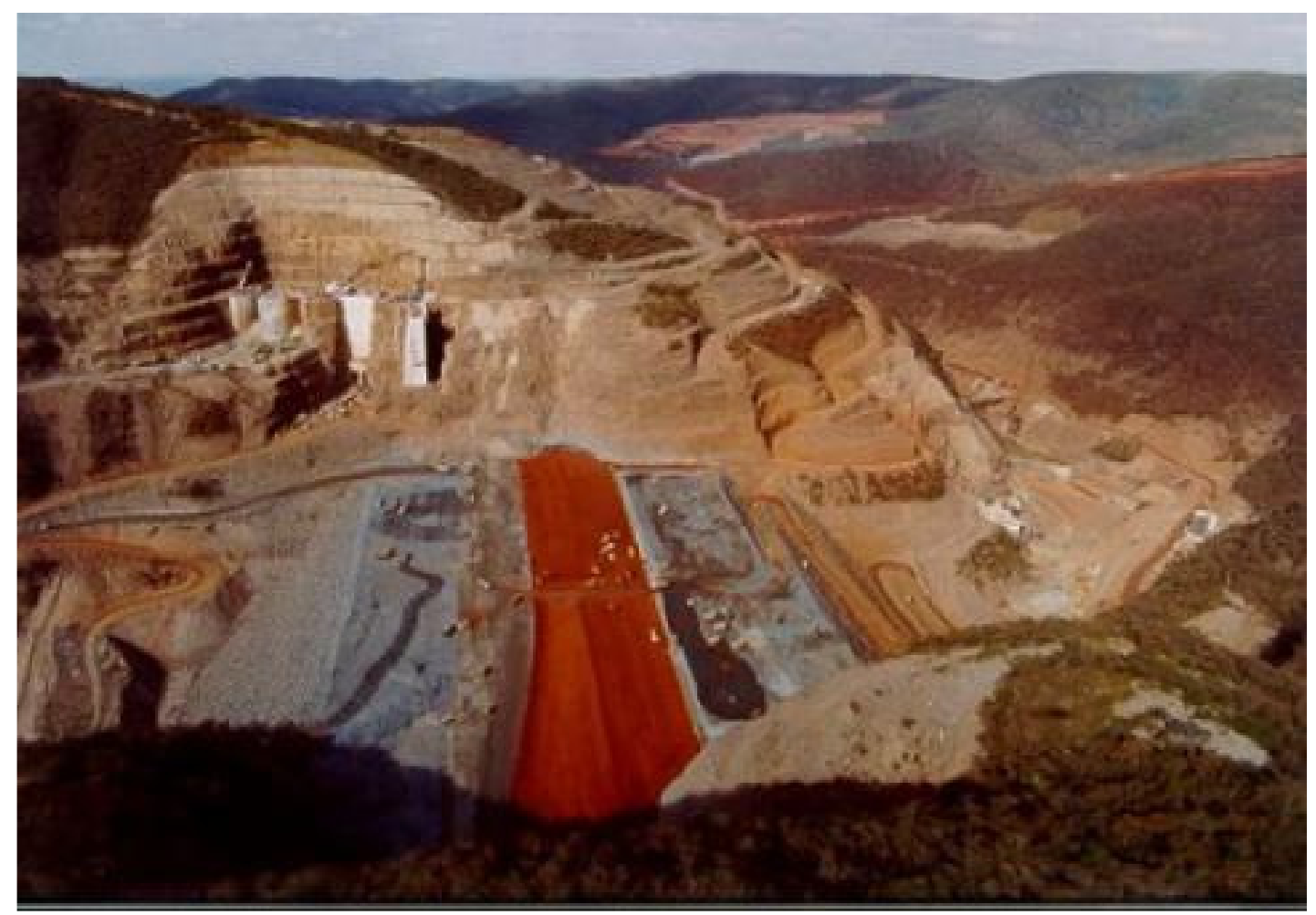

Figura 2. 4: Vista aérea lateral da construção da Barragem

Fonte: Extraído de http://www.irape.com.br. Acesso em 17/02/2010.

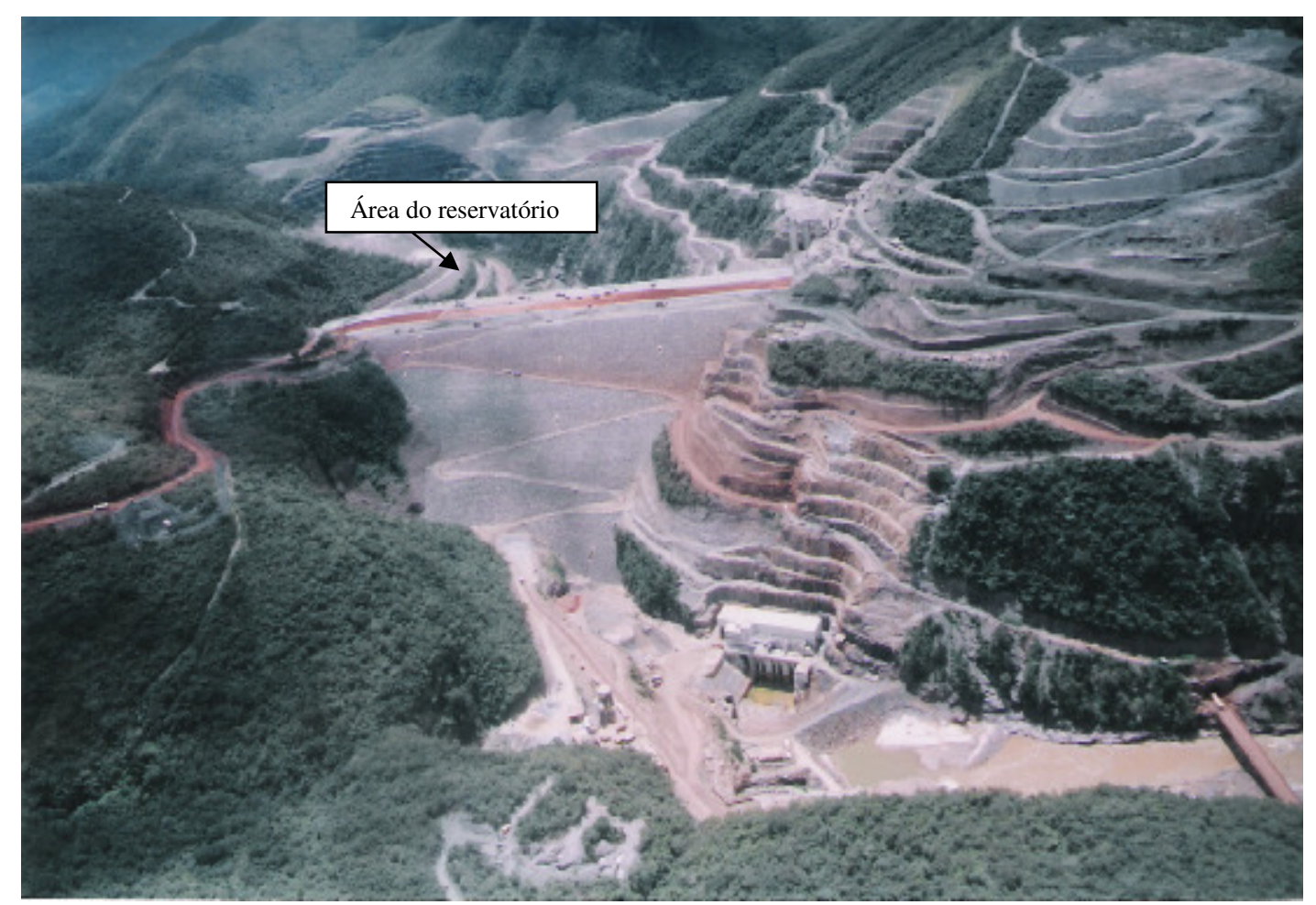

Figura 2. 5: Vista Geral da Obra sem o enchimento do Reservatório

Fonte: Extraído de http://www.irape.com.br. Acesso em 17/02/2010. 
O reservatório de Irapé ocupou uma região formada por comunidades tradicionais, dedicadas em sua grande maioria às atividades agropecuárias. Estas comunidades são compostas de lavradores, roceiros, vaqueiros e cortadores de cana. Também aparecem os pequenos comerciantes, os pequenos garimpeiros de diamante, ouro e cristal, os trabalhadores domésticos, e os que trabalham em estabelecimentos industriais ligados aos recursos naturais da região, como fábricas de cachaça, de rapadura, de doces e farinha. Assim, pouco menos de dois terços das famílias afetadas que moram na área rural, e o restante distribuem-se pela região (PCA, 2001).

Perante o EIA/RIMA e o Plano de Controle Ambiental - PCA, elaborado por consultores contratados pela Cemig, as áreas de estudo foram identificadas por meio de três unidades de análise, sendo elas: Área de Influência - (AI); Área de Entorno - (AE) e Área Diretamente Afetada (ADA).

Considerou-se como Área de Influência (AI):

a Área de Influência adotada para os estudos referentes aos aspectos físicos e bióticos foi definida pela bacia de drenagem relativa ao trecho do reservatório da UHE Irapé. Seus limites foram a casa de força da futura Usina Hidrelétrica de Grão Mogol, no rio Itacambiruçu e a futura Usina Hidrelétrica de Terra Branca, no rio Jequitinhonha (PCA, 2001, p. 8).

Quanto aos aspectos sociais, a AI foi definida pelos limites dos municípios que possuíam áreas a serem inundadas pela usina, sendo eles: Botumirim, Cristália, Grão Mogol, Berilo, José Gonçalves de Minas, Leme do Prado e Turmalina.

A Área de Entorno (AE) foi definida como

de forma geral, foi delimitada pela cota 600,00 $\mathrm{m}$ do entorno da cota de inundação a partir do N.A. máximo normal na cota 510,00 m. Para os aspectos relacionados ao meio sócioeconômico e cultural, considerou-se uma área no entorno do reservatório que englobasse os povoados situados próximos ao futuro reservatório e que representam espaço de moradia, convívio e suporte à população a ser afetada (PCA, 2001, p. 8).

Por fim, como a ADA, foi definida como "o conjunto de terras que será inundado e requerido para instalação das infraestruturas do empreendimento e construtivas" (PCA, 2001, p. 8). 
Quanto aos aspectos socioeconômicos e culturais, a ADA foi delimitada pelas áreas inundadas pela formação do reservatório das propriedades e povoados situados em seu entorno próximo. Os dados da tabela abaixo trazem a relação de municípios, a área inundada em Km2 e qual a porcentagem que isso representa para cada município:

Tabela 2. 1: Relação de municípios atingidos com relação ao total municipal

\begin{tabular}{lccc}
\hline \multicolumn{1}{c}{ MUNICÍPIOS } & ṔREA INUNDADA & $\begin{array}{l}\text { RELAÇAO } \\
\text { ÁREA MUNICIPAL }\end{array}$ \\
\hline BOTUMIRIM & & TOTAL DA \\
CRISTÁLIA & $25,66 \mathrm{~km}^{2}$ & $1,72 \%$ \\
GRÃO MOGOL & $38,03 \mathrm{~km}^{2}$ & $4,97 \%$ \\
BERILO & $15,84 \mathrm{~km}^{2}$ & $0,29 \%$ \\
JOSÉ GONÇALVES DE MINAS & $6,87 \mathrm{~km}^{2}$ & $1,28 \%$ \\
LEME DO PRADO & $25,86 \mathrm{~km}^{2}$ & $6,79 \%$ \\
TURMALINA & $4,91 \mathrm{~km}^{2}$ & $1,75 \%$ \\
\hline
\end{tabular}

Fonte: Arquivo da pesquisadora, com base na Ficha Técnica do empreendedor PCA - CEMIG, 2001.

Abaixo, a figura ilustrativa objetiva visualizar o reservatório e sua área de abrangência.

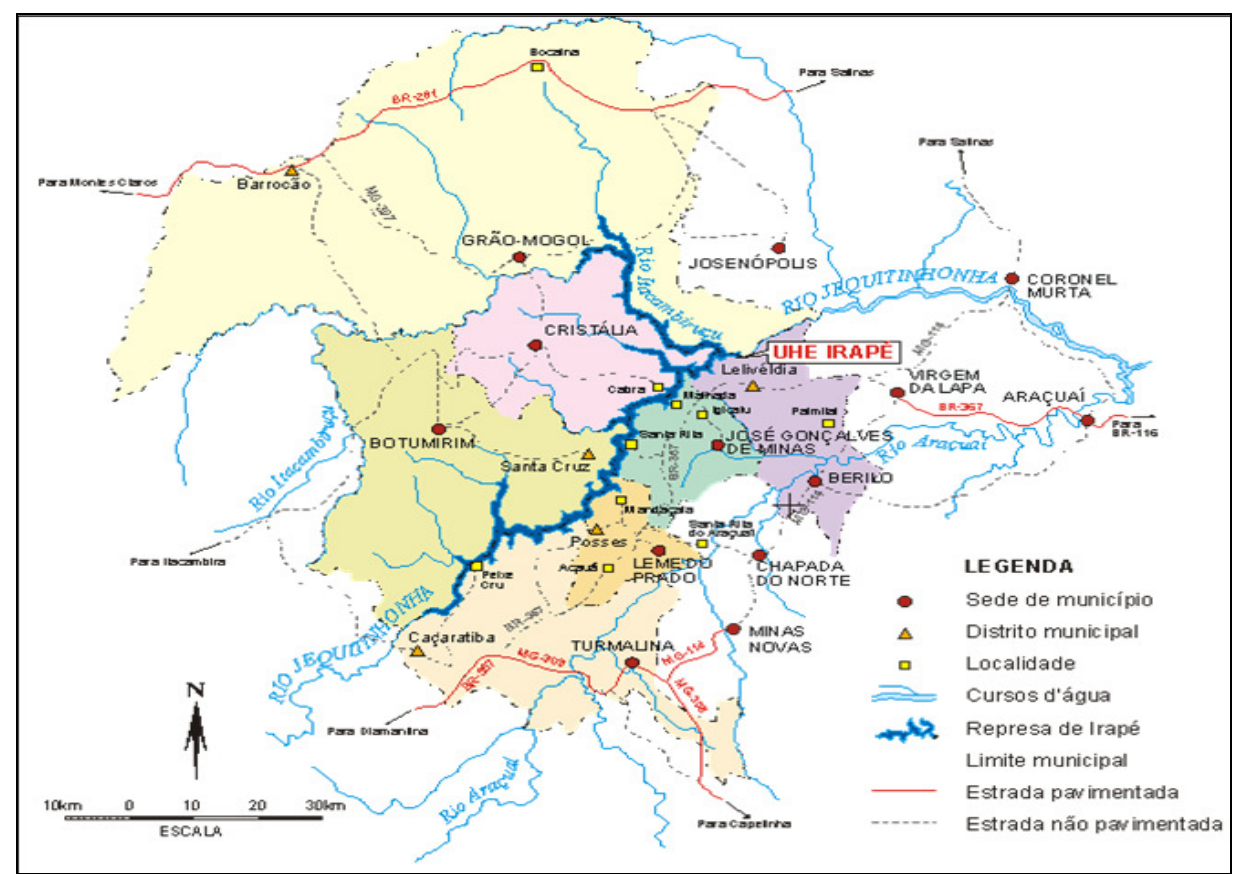

Figura 2.6: Área de abrangência do reservatório da Usina de Irapé

Fonte: Extraído de http://www.irape.com.br/mapas/index.asp. Acesso em 17/02/2010. 
Conforme estabelecido pela Resolução Conama ${ }^{\circ}$ 001/86, em seu Artigo $5^{\circ}$, uma das diretrizes que o Estudo de Impacto Ambiental (EIA), necessariamente, deve seguir é o "definir os limites da área geográfica a ser direta ou indiretamente afetada pelos aspectos, denominada área de influência do projeto, considerando, em todos os casos, a bacia hidrográfica na qual se localiza".

Sendo assim, a definição da(s) áreas(s) de influência constitui um passo importante, ao mesmo tempo que estratégico, uma vez que tal recorte define o espaço geográfico que, em conformidade com o conceito jurídico, seria aquele sujeito a sofrer os danos em decorrência da instalação/operação do empreendimento. Esse espaço seria, igualmente, a área que, em tese, seria objeto da atenção do empreendedor, como também do olhar atento da sociedade civil organizada e dos órgãos públicos competentes, no sentido de poder cobrar, sempre que houver necessidade as devidas responsabilidades por parte do empreendedor.

No entanto, as populações locais não participam diretamente da definição dessas áreas ou, como via de regra, algumas comunidades que se consideram atingidas (caso dos municípios que recebem o contingente de populações deslocadas), não se encontram nos limites das tais áreas de influência.

Além da Resolução Conama, a Eletrobrás possui outro material de apoio para o tema;que se delimita em duas unidades, quando se trata da área de influência: Área de Influência Direta (AID) e a Área de Influência Indireta (AII). No entanto, na prática, acaba-se por distorcer os conceitos, como por exemplo: geralmente, considera-se como Área de Influência Direta apenas as utilizadas para o canteiro de obras, as áreas de bota-fora e empréstimo, as vias de acesso à obra e outras necessárias à construção das usinas.

Embora não fique tão claro nos respectivos estudos ambientais, alguns empreendedores e seus consultores, como vimos no caso de Irapé, têm considerado como atingidas apenas as famílias, cujas residências ficarão submersas. No entanto, em todo o entorno do empreendimento, existem famílias que dependem do rio, da terra para a sobrevivência, assim como as famílias à jusante das barragens que também são atingidas de diversas maneiras.

Além disso, nas planícies de inundação, a deposição periódica de material orgânico torna as terras mais férteis, utilizadas pela população ribeirinha para culturas de subsistência e comercialização de pequenos excedentes, as chamadas culturas de vazante. 
[...] a terra que hoje ocupam, fruto da conquista se seu próprio trabalho e do legado dos seus ancestrais, além de ser seu lugar de produção e principal garantia de reprodução social, tem o sentido de "patrimônio familiar" e, como tal, não está à venda, não tem preço. Desta forma, a terra também agrega muitos sentidos, na medida em que extrapola seus limites geográficos, abrangendo outros espaços domésticos, dos vizinhos, os espaços comunitários que abrigam seus bens culturais, e as marcas de sua religiosidade, constituindo-se esse conjunto em seu território (ITACARAMBY 2006, p.74).

Outro ponto fundamental de discussão, quando tratamos de área de influência, está na posse da terra ocupada pelas famílias. Via de regra, é composta por várias categorias: posseiros, meeiros, agricultores, agregados, parceiros, indígenas, ribeirinhos dentre outros. Estes, muitas vezes, não se apresentam como proprietários de seu pedaço de terra, mas é notório nos vários EIA que a unidade preferencial para indenizações - quando acontecem - é com base na propriedade terra.

Com o enchimento do reservatório, a Usina de Irapé deslocou 1.151 famílias que viviam em 47 comunidades às margens do rio Jequitinhonha e seus afluentes. Os dados do Tabela 2.2 demonstram as comunidades, os municípios de origem e o número de famílias remanejadas.

Tabela 2. 2: Identificação das comunidades atingidas por município

\begin{tabular}{|c|c|c|}
\hline Comunidades & Município & $\begin{array}{l}\text { Famílias } \\
\text { serem } \\
\text { remanejadas }\end{array}$ \\
\hline Alegre, Ventania & Grão Mogol & 94 \\
\hline $\begin{array}{l}\text { Santa Cruz, Carqueja, Serafim, Santa Maria, Palmito, } \\
\text { Quebrabó, Bugio, Ouro Podre, Noruega, Buriti, Quebrado. }\end{array}$ & Botumirim & 206 \\
\hline Itacambiriçu, Soberbo, Sussuarana, São Miguel, Córrego & Cristália & \\
\hline $\begin{array}{l}\text { Dantas, Gangorrinha, Cachoeira, José de barros, Itapacoral, } \\
\text { Cabra. }\end{array}$ & & 327 \\
\hline $\begin{array}{l}\text { Jacuba, Bocaina, Degredo, Buriti, Catinguinha, Cana Brava, } \\
\text { Peixe Cru. }\end{array}$ & Turmalina & 240 \\
\hline $\begin{array}{l}\text { Porto Coris, Ribeirão, Corrente, Córrego de Engenho, } \\
\text { Mandassaia, Posses. }\end{array}$ & $\begin{array}{l}\text { Leme do } \\
\text { Prado }\end{array}$ & 132 \\
\hline
\end{tabular}




\section{Jose}

$\begin{aligned} \text { Igicatu, Malhada, Mandacaru, Baixão, Santa Rita, Sobrado. } & \text { Gonçalves } \\ & \text { de Minas }\end{aligned}$

Eixo da Barragem

Berilo

Fonte: Arquivo da pesquisadora com base em Zucarelli, 2006, p.159.

As famílias que habitam a região do Vale do Jequitinhonha, devem se acostumar e acabam adaptando-se às características do relevo da região que é representado por serras, chapadas, encostas e vales. Segundo o PCA (2001), as serras são formadas por afloramentos de rochas quartzíticas, com altitude entre $950 \mathrm{~m}$ a $1.467 \mathrm{~m}$, formando profundas gargantas. Os afluentes do rio Jequitinhonha e grande parte do rio Itacambiruçu têm suas nascentes nestas serras, que apresentam grande importância para a região. A segunda característica do Vale, são as chapadas, consideradas pelo PCA (2001), como áreas planas ou suavemente onduladas e apresentam altitudes entre $750 \mathrm{~m}$ a $1.000 \mathrm{~m}$ do nível do mar. O solo é profundo e permeável, com fertilidade muito baixa e acidez elevada, o que limita o aproveitamento agrícola por parte dos pequenos e médios produtores. Nas bordas das chapadas, o solo é de baixa fertilidade, ácido e cascalhento. E apresenta inviabilidade de utilização agrícola, sendo recoberto, por vegetação nativa (cerrados).

Como indica o PCA (2001), os vales e terraços são encostas que ligam as chapadas às calhas dos rios. São unidades muito representativas na área diretamente afetada. Os terraços são patamares estreitos, situados entre as altitudes de $550 \mathrm{~m}$ a $650 \mathrm{~m}$ do nível do mar. As encostas e fundos de vales podem ser conhecidos também como grotas (GALIZONI, 2000) são caracterizados pelo aumento de declividade em direção ao leito dos cursos de água. Nas proximidades dos cursos d'água, nas planícies, os solos das encostas, embora rasos e inclinados, apresentam boa fertilidade natural.

Com relação ao uso e ocupação da área de influência e da área diretamente afetada o PCA (2001) indica que as chapadas são ocupadas por remanescentes de cerrados, pastagens naturais e reflorestamento. As atividades agrícolas são pouco representativas, restringindo-se às lavouras de café e poucas áreas de agricultura familiar, já nas encostas e vales onde existe uma fertilidade natural, a exploração agrícola familiar desenvolvia-se nos baixos cursos dos afluentes dos rios Jequitinhonha e Itacambiruçu, onde ocorriam solos mais férteis e maior 
disponibilidade de água. Eram solos cultivados, basicamente, com cana-de-açúcar, arroz, feijão, milho e com hortas domésticas.

A vegetação do Vale na área diretamente afetada é constituída basicamente pela mata seca, cerrado e mata ciliar. Nos últimos tempos, o Vale do Jequitinhonha vem sofrendo contínuas alterações em seu quadro natural em razão das queimadas, desmate para produção de carvão e reflorestamento de eucalipto (PCA, 2001; RIBEIRO, 2008).

Os principais aspectos socioeconômicos dos municípios considerados: os da margem direita do rio Jequitinhonha - Berilo, José Gonçalves de Minas, Leme do Prado e Turmalina e os da margem esquerda - Grão Mogol, Botumirim e Cristália. Várias características são comuns às duas regiões, diferenciando-as de outras áreas no próprio estado de Minas Gerais.

As atividades econômicas predominantes nas duas regiões eram a pecuária de corte mais importante na margem esquerda que na direita; a mineração e o garimpo - com predominância maior na margem direita; e o reflorestamento - atividade desenvolvida, nas últimas décadas, em grandes extensões de terra em alguns municípios localizados nas duas margens do rio Jequitinhonha (PCA, 2001).

As condições das duas regiões favoreceram a ocupação dos vales dos rios por pequenas propriedades rurais voltadas para a produção familiar, atividade que absorve uma grande quantidade de mão de obra durante o período chuvoso e que liberava parcela de trabalhadores para serviços temporários em outras regiões do País. A renda adquirida no trabalho temporário é um aporte de recursos importantes para a complementação da renda da pequena produção agrícola familiar (RIBEIRO, 2008).

O PCA (2001, p. 14) identifica algumas características para a área de influência, tais como: a Área Diretamente Afetada apresenta uma estrutura viária precária, e a manutenção das estradas municipais é pouco frequente. Na região, é comum a localização de domicílios a que se tem acesso somente a pé, a cavalo ou em pequenos barcos; a segunda característica, está relacionada às atividades econômicas que se concentram na agricultura e extrativismo, com predominância das culturas alimentares, e na pecuária, que se apresenta diversificada e sustentada em pequenos rebanhos bovinos, de suínos e aves. Os excedentes são comercializados nos núcleos urbanos regionais, esta comercialização é importante, tanto do ponto de vista da economia familiar como no abastecimento à população desses núcleos. Algumas comunidades eram importantes no fornecimento de mercadorias e serviços para a população rural, como Malhada, Catutiba, Santa Rita, Mandassaia e Posses, à margem direita, Cabra e Santa Cruz, à margem esquerda. 
Após a conclusão do projeto, o investimento total de obra foi apurado, como demonstram notícias e entrevista realizada com técnicos da CEMIG. O orçamento inicial era cinco vezes menor que o realizado, o que caracteriza uma variação entre acordado e realizado.

Julgamos interessante mostrar o número afirmado em entrevista com os técnicos da CEMIG, pois não encontramos referência em nenhum local. Desta forma, estaremos trabalhando com o dado coletado em campo, o que demonstra maior proximidade com o realizado.

No próximo capítulo, será demonstrado, o que foi acordado pelo empreendedor como atingidos com a criação do Termo de Ajustamento de Conduta (TAC), assim como a metodologia adotada para apurar as indenizações. 


\section{CAPÍTULO III: O ACORDADO}

\subsection{Termo Ajustamento de Conduta - TAC}

A elaboração do Termo de Ajustamento de Conduta (TAC) foi uma tarefa complexa e sua assinatura, como retrata Zucarelli (2006) trouxe duas importantes significações.

[...] a primeira refere-se ao teor simbólico do documento, que reflete a existência de uma conduta transgressora daquele que descumpriu um direito fundamental da coletividade; a segunda é o reconhecimento das comunidades rurais do Vale do Jequitinhonha enquanto atingidas pelo projeto hidrelétrico (ZUCARELLI, 2006, p.112).

Dentro da história de luta dos atingidos por Irapé, a assinatura desse termo mostra o reconhecimento perante os fatos, "foi a conquista mais significativa que estes tiveram durante o licenciamento". (ZUCARELLI, 2006, p.112).

Como via de regra, a recomposição das famílias atingidas por barragens no País revela uma série de falhas, no que diz respeito à continuidade da reprodução social e econômica das comunidades.

O TAC visa, essencialmente, a garantir a revisão dos planos, programas e projetos do PCA, em face não só das insuficiências verificadas no processo de licenciamento, como também a necessidade de adequação da implementação de medidas sócio ambientais ali propostas. Muitos "tópicos fazem referência às condicionantes impostas pela FEAM, não cumpridas pela CEMIG desde, a fase de LP e outros entraram e saíram do TAC, com base em um intenso processo de negociação" (ZUCARELLI, 2006, p. 115).

A primeira reunião para o desenvolvimento da redação do TAC aconteceu no dia 8 de maio de 2002 e a assinatura do documento ocorreu em 05 de julho de 2002. Foram realizadas mais de 60 reuniões. Como celebrantes assinaram: o Ministério Público Federal, o Estado de Minas Gerais, a Fundação Estadual do Meio Ambiente, a Companhia Energética de Minas Gerais. Em contrapartida, assinaram: a Fundação Cultural Palmares, a Associação Quilombola Boa Sorte e a Comissão dos Atingidos pela Barragem de Irapé.

$\mathrm{Na}$ primeira reunião para o desenvolvimento do Termo, a CEMIG não apresentou nenhuma proposta. No segundo dia, foi apresentada uma proposta inicial pelo conselheiro da CIF/COPAM, Sr. Jader Pinto de Campos Figueiredo, porém a pauta inicial foi considerada 
vaga e foi exigida da empresa CEMIG a apresentação da pauta inicial, para então iniciar a negociação.

Após a proposta de abandono do desenvolvimento do Termo, feito pelos atingidos e pelo Procurador da República, o empreendedor trouxe uma proposta na semana seguinte como pauta inicial - com propostas para os atingidos, para a negociação.

Contudo como contrapartida, havia as reivindicações dos atingidos, o parecer técnico da FEAM e a normalização sobre os parâmetros de reassentamento do Instituto Nacional de Colonização e Reforma Agrária - INCRA.

A metodologia utilizada para conduzir as reuniões se pautava-se na seguinte maneira:

[...] a Cemig ou a Comissão de Atingidos elaborava uma proposta e era dado algum tempo para que os autores pensassem sobre o assunto e definissem um encaminhamento; os representantes do Ministério Público eram responsáveis pelo processo, pela redação e apresentação do que haveria a ser discutido. Quando as negociações eram mais difíceis, sem a formação de um "consenso" entre as partes, o Procurador da República era chamado para intervir (ZUCARELLI, 2006, p. 120).

Assim, as questões com maior polêmica estavam diretamente ligadas ao que denominamos neste trabalho de "custos sociais" - às indenizações sobre o tamanho e a qualidade das terras para o reassentamento, a questão da água nos terrenos, as terras de espólio, as terras de herdeiros, o garimpo artesanal, o extrativismo vegetal e o desmate nas áreas destinadas ao reservatório da UHE de Irapé.

A CEMIG tinha uma meta a ser cumprida, a empresa tentava moldar o TAC, de acordo com seu orçamento as experiências, assim como o referido estudo de caso o demonstram que, se não se incluir no investimento inicial o custo com deslocamento e reassentamento da população direta e indiretamente atingida, haverá uma variação razoável no investimento total da obra ( ZUCARELLI, 2006, p.121).

Em um determinado momento da negociação, a CEMIG apresentou um novo cronograma de execução da obra, reduzindo-o de 4 para 2 anos e meio; o que significava um decréscimo de um 1 ano e meio. Morel Queiroz da Costa Ribeiro (FEAM), na época, viu isto como ameaça ao cumprimento do TAC pela CEMIG (Entrevista na sede da FEAM, 21/11/2008, Belo Horizonte, MG). 
Portanto, após um longo período de negociação entre as partes, foi elaborado com o Ministério Público Federal um prazo para o Acordo ser cumprido. A Licença de Instalação foi obtida em 2002, condicionada À elaboração e assinatura do Termo de Ajuste de Conduta, nomeado posteriormente, apenas como Termo de Acordo.

As primeiras páginas do Termo, desde a cláusula primeira até cláusula sétima, referem-se ÀS informações a respeito dos direitos e deveres do empreendedor CEMIG para com a população atingida. Inicialmente, a conclusão do Termo de Acordo deixou os atingidos tranquilos quanto às indenizações e considerações.

Cabe informar que só serão analisadas as determinações mais importantes do Termo de Acordo, constantes do Anexo I “Ações de Remanejamento”, Anexo II “Ações e programas específicos para remanejamento da comunidade de Porto Coris", Anexo III "Programa de reconhecimento, preservação e valorização do patrimônio cultural das comunidades impactadas pela UHE Irapé”. As determinações do Anexo IV "Programas e ações ambientais" não são objetivo direto desta dissertação.

O Termo de Acordo foi concluído com 167 condicionantes que tratavam, desde os direitos até as minuciosas informações para resguardar a população,

Mas na área de abrangência do reservatório, a comunidade de Porto Coris, situada às margens do Rio Jequitinhonha, no município de Leme do Prado, foi reconhecida pelo Governo Federal de Minas Gerais como comunidade remanescente de quilombo. Isto fez com que seu território fosse recentemente titulado pela Fundação Cultural Palmares. Em face desta situação, foi realizado um anexo no Termo de Acordo, que só designava a comunidade quilombola em defesa dos direitos.

O processo administrativo para o levantamento de aspectos socioeconômicos de Porto Coris afirma que o RIMA não traz comentários diretos ou mais detidos sobre a comunidade. Desta forma, a FEAM solicita à CEMIG que apresente um parecer técnico sobre a Comunidade Tradicional de Porto Coris, atestando ou não sua condição de remanescente de quilombo.

Além de escola, cemitério, igreja e um telefone, Porto Coris tinha 86 moradores, todos parentes do ex-escravo Germano Alves Coelho, cuja existência é atestada em documento de 1888. Ninguém de fora jamais adquiriu terras na comunidade. Com exceção de uma família, não há registros de direitos individuais. Ali, plantavam amendoim, milho, feijão, mandioca e cana, com ajuda da fertilidade natural das áreas de grota, como são chamados os vales. Grandes áreas foram reservadas para finalidades coletivas, com utilidades marcadas por 
consenso, como produção de madeira ou descanso de terras. Quase não há homens jovens na vila; migrações sazonais para colheita de cana e café no interior de São Paulo são típicas na região.

Dentro do Anexo I “Ações de Remanejamento”, foram definidas as modalidades de remanejamento, conforme segue: Reassentamento; Realocação na área remanescente da propriedade atingida; Troca por outra terra (permuta) e Indenização Monetária (TAC, 2002).

A formação do reservatório atingiu diretamente às populações da área rural que residiam em sua grande maioria, à beira do rio e à agricultura local.

Para dar suporte técnico à elaboração dos projetos de reassentamento, a CEMIG assinou convênio com a Empresa de Assistência Técnica e Extensão Rural do Estado de Minas Gerais (EMATER) para realizar o levantamento das áreas.

O critério de seleção aplicado para selecionar as áreas adequadas para os reassentamentos considerou seis fatores: o primeiro, relacionado à localização das áreas: poderá se localizar em qualquer município do Estado de Minas Gerais, seguindo uma ordem de prioridade: em primeiro, o Município de origem do grupo; em segundo, Municípios do Alto Jequitinhonha, área de abrangência do empreendimento; em terceiro, municípios localizados em outras regiões do Estado de Minas Gerais, levando em consideração os critérios de qualidade de terra e água; o segundo fator, leva em consideração o tamanho da propriedade a ser adquirida: teriam preferência as médias e grandes propriedades, para tentar minimizar a ruptura dos grupos, desta forma, manter as relações sociais existentes nas comunidades; já o terceiro critério, está ligado à qualidade da terra, a fim de assegurar ao atingido terras equivalentes às que ocupava. A classificação das terras será demonstrada, posteriormente, neste trabalho. Por sua vez, o quarto, diz respeito à disponibilidade de água da propriedade às famílias reassentadas, os custos com instalação de instrumentos ou mecanismos destinados ao aproveitamento da água serão arcados pela CEMIG; e o quinto critério, leva em consideração as propriedades: devem possuir boas condições de acesso durante todo o ano aos núcleos mais próximos. Finalmente, o sexto critério, está relacionado à energia elétrica:é necessário haver uma proximidade com a rede de energia elétrica.

A opção prioritária do remanejamento das famílias atingidas foi do reassentamento. Seria de responsabilidade da CEMIG fornecer todos os dados e informações necessárias para que as famílias pudessem tomar a decisão mais adequada, conforme seus interesses aos seus interesses. 
O público-alvo identificado no Termo de Acordo está representado pelos “a) proprietários de áreas afetadas; b) posseiros, com suas respectivas entidades familiares, que residam e/ou trabalhavam no espaço diretamente impactado pela UHE Irapé; c) parceiros e agregados, com suas respectivas entidades familiares,que residam e/ou trabalhem regularmente no espaço diretamente impactado pela UHE Irapé; d) filhos de proprietários, de posseiros, de parceiros e de agregados, maiores de 18 anos, que residam e/ou trabalhem no espaço diretamente impactado pela UHE Irapé, e os que não tenham ainda constituído família; e) membros das famílias ou grupos de parentesco referidos nas letras a e b deste item que não residam ou trabalhem no espaço diretamente impactado pela UHE Irapé, nem em áreas afetadas pela ruptura de relações sociais ou desativação de serviços básicos hoje existentes, mas que tenham mesmo grau de parentesco em relação a proprietários ou posseiros de terras havidas por herança e mantidas em comum que residam e/ou trabalhem no espaço e nas áreas mencionadas neste item" (TAC, 2002, p.15). Assim como será reconhecido o direito ao reassentamento às famílias que ficarão isoladas, seja pela remoção das famílias vizinhas implicando a desestruturação de relações sociais afetivas.

O critério utilizado para a definição dos tamanhos dos lotes leva em consideração a condição familiar de cada indivíduo.

Segundo o Termo de Acordo, "os lotes e benfeitorias a serem destinados aos proprietários e posseiros que optarem pelo reassentamento deverão ter uma quantia no mínimo equivalente a avaliação das terras, benfeitorias produtivas e não reprodutivas de suas propriedades" (TAC, 2002, p. 16).

Por meio do Termo de Acordo foi definido que um módulo fiscal à margem direita corresponde a 40 hectares e à margem esquerda, a 50 hectares. Para cada família (proprietário, posseiro ou agregado), um módulo fiscal; filho maior de 18 anos e casado um módulo fiscal; filho maior de 18 anos e solteiro dez hectares e terras de herança (herdeiros ausentes) um módulo e meio fiscal.

Todos os módulos deveriam apresentar os seis critérios já mencionados, assim como propiciariam a diversidade e a sustentabilidade da agricultura familiar, bem como as condições que permitissem a continuidade das atividades de subsistência anteriormente desenvolvidas pelo reassentamento.

Quanto à moradia nos reassentamentos, de acordo com o Termo, os reassentados teriam direito de definir o tipo de casa, onde pretendiam morar e poderiam construir ou empreitar a obra de terceiros (responsabilidade da CEMIG). A CEMIG deveria comprometer- 
se também a fornecer às famílias reassentadas mudas, para formação de pomares e sementes para plantio da primeira safra na nova área.

\subsection{Metodologia utilizada para indenização monetária de terras ou benfeitorias}

Atualmente, existe uma crescente demanda para desenvolvimento de metodologias que mostrem alto conteúdo técnico e eficiência para se buscar a quantia dos imóveis rurais, seus frutos e benfeitorias nos processos de indenização em áreas atingidas por empreendimentos hidrelétricos.

Tendo em vista esta complexidade do assunto, a Associação Brasileira de Normas Técnicas (ABNT) procurou disciplinar também a matéria, criando procedimentos específicos objetivando minimizar divergências entre as partes envolvidas na negociação.

Assim, a partir da Norma Brasileira NB-613/81, foi desenvolvida uma norma atualizada publicada sob o título de Norma Brasileira Registrada - NBR 8.799, em fevereiro de 1985, que fixa as condições exigíveis para avaliação de imóveis rurais de seus frutos e de seus direitos sobre os mesmo.

tem por objetivo: classificar a natureza dos imóveis rurais, dos seus frutos e dos direitos a avaliar, instituir a terminologia, as convenções e as notações em trabalhos avaliatórios desta espécie, definir a metodologia básica aplicável às mesmas avaliações; prescrever diretrizes para apresentação de laudos. Deve ser aplicada em todas as manifestações escritas de trabalhos que caracterizam valor de imóveis rurais, de seus frutos ou de decisões sobre os mesmos (NORMA ABNT 8.799/85 ${ }^{19}$, resumo).

No entanto, em diversas situações prevalece a experiência e o bom senso do avaliador. Alguns fatores tornaram-se mais valorizados dentro do contexto do imóvel rural, sem, no entanto, menosprezar três fatores básicos: utilidade, raridade e localização das áreas.

Nestes três fatores, a Norma entende que estão incluídas as condições da região, com o acesso e as condições de tráfego o ano inteiro e ainda, a topografia da área. $\mathrm{O}$ fator água superficial, base importante do processo produtivo na região, também, ocupa papel relevante no processo de avaliação. Outros fatores, como fertilidade e drenagem, passaram a ter maior interferência no valor global da avaliação.

\footnotetext{
${ }^{19}$ Atualmente está norma foi substituída pela ABNT 14.653-3:2004.
} 
Dentre os processos relacionados pela Norma, outro método utilizado foi o Método Comparativo Direto de Dados de Mercado. Este propõe que o avaliador efetue uma pesquisa de mercado, coletando amostras de imóveis semelhantes ao avaliado para, posteriormente, proceder a uma etapa de homogeneização, de forma a possibilitar uma comparação direta entre o valor das amostras e o valor do imóvel em questão.

Portanto, ainda havia necessidade de avaliar separadamente a terra, as benfeitorias reprodutivas e as benfeitorias não reprodutivas.

\subsection{Avaliação das terras}

A avaliação da terra foi feita em função de sua capacidade de utilização do solo, foi mapeada em conformidade com o Manual Brasileiro para Levantamento da Capacidade de Uso de Terra, Escritório Técnico da Agricultura (ETA) - Brasil/Estados Unidos, 1971. Como recomendação complementar também foi utilizado, o Manual de Avaliação de Propriedades Rurais, editado pelo Professor Marcelo Rossi de Camargo Lima responsável pelos procedimentos contidos na Norma 8.799 já referida.

Uma atividade que deveria ter sido realizada para a classificação das terras, conforme documento (AHE IRAPÉ, $s / n^{20}$ ) seria de fotointerpretação em fotografias aéreas e ortofotocartas obtidas com base na cobertura aerofotogramétrica. Após a fotointerpretação, seria feito um trabalho complementar de campo para realizar as vistorias locais, objetivando ao levantamento de dados complementares necessários para se proceder com a avaliação.

A classificação das terras estava separada por três tipos: Terras cultiváveis - classe I: aparentemente, sem problemas especiais de conservação, classe II: Terras cultiváveis com problemas simples de conservação, classe III: Terras cultiváveis com problemas complexos de conservação e classe IV: Terras cultiváveis apenas ocasionalmente ou em extensão limitada com sérios problemas de conservação. A segunda característica é de Terras cultiváveis, apenas para culturas permanentes e adaptadas para pastagens e reflorestamento tendo três classes - classe V: Terras cultiváveis apenas em casos especiais, de algumas culturas permanentes e adaptadas, em geral, para pastagens ou reflorestamento, sem necessidade de práticas especiais de conservação, classe VI: Terras cultiváveis apenas em casos especiais de algumas culturas permanentes e adaptadas, em geral, para pastagens ou reflorestamento, com problemas simples de conservação; classe VII: Terras cultiváveis apenas

\footnotetext{
${ }^{20}$ Documento em anexo.
} 
em casos especiais de algumas culturas e adaptadas em geral para pastagens ou reflorestamento, com problemas complexos de conservação. Por fim, a terceira caracterização das Classes de Capacidade de uso da Terra é Terras impróprias para vegetação produtiva com apenas uma classe, classe VIII: Terras impróprias para cultura, pastagens ou reflorestamento, podendo servir apenas como abrigo da Fauna silvestre, como ambiente para recreação ou para fins de armazenamento de água (AHE Irapé, s/n, p.2).

Um grande problema enfrentado no Vale é a disposição de terras cultiváveis. As conhecidas chapadas, por estarem localizadas em locais altos, possuem uma grande dificuldade referente ao acesso à água, pois as áreas mais férteis localizam-se nos vales, próximas ao rio.

Para avaliação das terras, no primeiro momento, estas são separadas pelas classes apresentadas acima e, posteriormente, são classificadas em função de sua capacidade produtiva.

O grau de capacidade leva em consideração quatro fatores: A letra $\underline{\mathbf{s}}$ simboliza a soma de bases, ou seja, a riqueza do solo em nutrientes - Fertilidade; à letra e que corresponde ao declive do terreno e reflete riscos de erosão - Erosão; já a letra w refere-se às limitações de uso da terra pelas condições inerentes ao excesso de água no solo - a letra $\underline{\mathrm{c}}$ que reflete as condições climáticas na região - Caráter Hídrico e Limitações Climáticas (secas prolongadas). Para cada capacidade foi estabelecido um valor de mercado, estipulado perante suas condições de produtividade, como demonstram os dados da Tabela 3: 
Tabela 3.1: Valores médios da Terra Nua por Subclasse de Capacidade de Uso

\begin{tabular}{|c|c|c|}
\hline $\begin{array}{l}\text { Classes de Capacidade } \\
\text { de Uso da Terra }\end{array}$ & $\begin{array}{l}\text { Subclasse de } \\
\text { Capacidade }\end{array}$ & Valor R\$/há \\
\hline \multirow[t]{2}{*}{ Classe I } & $\mathrm{I}$ & 971,32 \\
\hline & II s & 854,76 \\
\hline \multirow[t]{2}{*}{ Classe II } & $\mathrm{II} \mathrm{e}$ & 777,05 \\
\hline & II e, s & 718,78 \\
\hline \multirow{4}{*}{ Classe III } & III s & 488,77 \\
\hline & III w & 621,64 \\
\hline & III e & 372,99 \\
\hline & III e, s & 543,94 \\
\hline \multirow{3}{*}{ Classe IV } & IV s & 505,09 \\
\hline & IV e & 466,23 \\
\hline & IV e,s & 427,38 \\
\hline Classe V & V w & 349,67 \\
\hline \multirow{2}{*}{ Classe VI } & VI s & 310,82 \\
\hline & VI e,s & 233,12 \\
\hline \multirow{2}{*}{ Classe VII } & VII e & 194,26 \\
\hline & VII e, s & 135,98 \\
\hline Classe VIII & VIII & 67,99 \\
\hline
\end{tabular}

A proposta foi adotar valores médios em função das classes de capacidade de uso e das limitações de uso do solo agrupadas em quatro fatores representadas pelas letras. Como podemos perceber, os valores atribuídos são diretamente relacionados com a capacidade de produção e a qualidade das terras. Esta tabela foi elaborada por meio de pesquisa de preços na região.

Os atingidos por barragens foram beneficiados, com a publicação da PORTARIA/INCRA/P/N ${ }^{\circ}$ 351, de 25 de maio de 2004, publicada no D.O., de 26 de maio de 2004, Seção 2, p. 27, art $1^{\text {}}$, a que determina que sejam incluídos no Programa Nacional de Reforma Agrária, os agricultores atingidos com a construção de barragens para aproveitamento hidreletrico, com área remanescente e até três módulos rurais, que tenham 
sido cadastrados e selecionados pelo INCRA, com o objetivo específico para os créditos do PRONAF “A”; dos Serviços de Assessoria Técnica, Social e Ambiental à reforma Agrária ATES e do Programa Nacional de Educação na Reforma Agrária - PRONERA.

\subsection{Avaliação das Benfeitorias Reprodutivas e Não Reprodutivas}

Segundo documento AHE Irapé (s/n) as benfeitorias reprodutivas são as que geram rendimentos com seu cultivo. Diferente do documento elaborado pela CEMIG acreditamos que toda terra possuí um valor.

\subsection{Culturas Anuais}

Conforme documento AHE Irapé, ( $\mathrm{s} / \mathrm{n})$ as culturas anuais seriam indenizadas com base na soma dos valores em primeiro lugar relacionados "ao custo de reposição com base nos custos regionais médios, tomando-se por base as modalidades de plantio adotadas localmente". Em segundo lugar, pelo valor econômico da plantação correspondente "ao valor presente de rendimentos líquidos da safra pendente, no momento da avaliação, deduzidos os custos vincendos da mesma e multiplicado por um coeficiente de risco" (AHE Irapé, s/n, p.6). Ou seja, o valor da produção foi realizada com base nos preços de mercado da espécie e/ou variedade cultivada.

\subsection{Culturas Perenes}

Para a indenização de "lavouras seriam contadas todas as plantas de cada espécie, classificando-as por idade de até 12 meses e acima de 12 meses" (AHE Irapé, s/n, p.6). A definição por apenas duas faixas de idade acontece em virtude de existir uma predominância de pomares domésticos e pela falta de registros e informações sobre a idade das plantas.

Sendo assim, foram considerados dois aspectos comuns na região: para pomar doméstico, aquele que corresponde "ao pomar explorado para consumo próprio, cujos excedentes poderão ou não ser comercializados"; quando isso acontece, geralmente é com o excedente que é comercializado em feiras locais; "comercializando o produto in natura ou na forma de compotas, conservas, molhos, etc" (AHE Irapé, s/n, p.6).

O método utilizado para a indenização do pomar doméstico está relacionado a três fatores: custo das mudas: sementes e insumos; Custo do plantio e dos tratos culturais e pela produção cessante: valor líquido das safras que deixarão de ser colhidas (AHE Irapé, s/n, p.6). 
A produção cessante é a compreendida entre a avaliação e o início de produção da nova cultura a ser implantada (AHE Irapé, s/n, p.6).

$\mathrm{Na}$ região atingida, outro aspecto comum é o Pomar Comercial "aquele com fins comerciais", neste caso, a instrução da norma é empregar o método do custo de reposição acrescido do valor econômico da cultura.

Este valor econômico deverá ser equiparado ao valor presente dos rendimentos líquidos das safras correspondentes ao número de anos, menos um, necessários para que a plantação atinja a época de produção da espécie plantada, multiplicado por um coeficiente de risco, adicionando-se, quando for o caso, o rendimento líquido da safra pendente de fato, na ocasião da avaliação, deduzidos os custos vincendos da mesma (ABNT 8799/85 apud AHE Irapé, s/n, p.7).

Para facilitar o entendimento, o valor econômico deverá considerar preferencialmente o período de formação, vida útil da cultura e safras já colhidas.

\subsection{Pastagens, Essências Florestais Implantadas}

O valor da indenização seria calculado com base no custo das formação de pastagens de características similares. Já para as áreas de reflorestamento o valor de indenização corresponderá ao custo de implantação acrescido do valor da expectativa de produção do primeiro corte previsto. Estas características seriam apenas para as áreas inundadas (AHE Irapé, s/n, p.7).

\subsection{Avaliação das Benfeitorias Não Reprodutivas}

As benfeitorias não reprodutivas seriam avaliadas pelo seu valor de reposição, ou seja, pelo valor do recurso financeiro necessário para construir uma benfeitoria nova equivalente, “dentro do padrão adequado de qualidade" (AHE Irapé, s/n, p.6).

Como benfeitorias não reprodutivas, foram consideradas as construções (edificações e instalações) e obras e trabalhos de melhoria das terras (desbravamento, conservação de solos, sistematização, construção da fertilidade e manutenção).

Desta forma, identificaram-se, por meio da pesquisa de mercado, os valores de cada benfeitoria nos municípios, calculou-se uma média para conseguir identificar os valores de 
indenização para as benfeitorias. A próxima tabela foi a referente à conclusão dos valores para indenizar, tanto as benfeitorias não reprodutivas como as outras categorias.

Tabela 3.2: Indenização de Benfeitorias não reprodutivas

\section{Descrição das benfeitorias não reprodutivas}

Valor

indenizado

\section{Casa Residencial}

Pagamento de valor correspondente a uma casa nova em função da casa cadastrada e dentro dos padrões usuais utilizados pela CEMIG.

$\mathrm{R} \$ 308,08 / \mathrm{m}^{2}$

\section{Outras Benfeitorias}

Cerca de arame liso, 5 fios, postes de madeira tratados no pé.

$\mathrm{R} \$ \quad 4,70 / \mathrm{m}$

linear

Galpão estrutural metálico com $4 \mathrm{~m}$ de pé direito, cobertura de telhas de fibrocimento e piso cimentado.

$\mathrm{R} \$ 200 / \mathrm{m}^{2}$

Galpão sem piso cimentado.

$\mathrm{R} \$ 179,00 / \mathrm{m}^{2}$

Paiol $3 \mathrm{~m} \times 3 \mathrm{mx} 3 \mathrm{~m}$, com sapata simples, blocos de concreto $(0,40 \mathrm{mx}$

0,40mx 0,30m) sem revestimento, telhas de fibrocimento, meia água com $R \$ 135,00 / \mathrm{m}^{2}$

portão e janela de madeira.

Curral padrão $8 \mathrm{mx} 10 \mathrm{~m}$ com 4 réguas serradas, esteios tratados de $2 \mathrm{mx} 2 \mathrm{~m}$ e pé direito de $3,2 \mathrm{~m}$, pido de terra batido, com 4 porteiras, mais $\mathrm{R} \$ 48,00 / \mathrm{m}^{2}$ coberta para ordenha de $5 \mathrm{mx} 4 \mathrm{~m}$ com piso de concreto e pé direito de $3 \mathrm{~m}$.

Fonte: Arquivo da pesquisadora baseada na Proposta para Avaliação dos imóveis, CEMIG (2002, p. 8).

Para elaboração desta metodologia houve a contratação de um avaliador por parte da CEMIG e, em contrapartida, os atingidos conseguiram contratar um avaliador para formular e quantificar as indenizações. Conforme depoimento do Sr. José Antonio da Comissão dos atingidos pela UHE de Irapé que afirma a contratação por ambas as partes para avaliação das benfeitorias reprodutivas e não reprodutivas.

[...] quando acertô o Termo de Ajuste de Conduta, a CEMIG ia contrata, né? Um avaliador pra tá fazendo essa avaliação, então, a gente conseguiu com a CEMIG que a gente contratasse também um avaliador e que ela pagava. Então, a gente conseguiu também (...), a gente contratou um rapaz em Governador Valadares que chamava, se 
não me engano Repolho, ele veio pra cá. Ele elaborou uma planilha e essa planilha nos sentamo. Ele apresentou ela, e disse, "ó que eu consegui chegar foi isso, não é muito, mas tá bom” (...) a proposta era que, após ele apresentar essa planilha pra gente, ele leva ela pro outro perito, ele senta os dois, e o que divergisse eles acerta lá, né? Então foi o que eles fizeram (Entrevista Sr. José Antonio, Comissão dos Atingidos pór Irapé, 27/11/2008, Turmalina, MG).

No próximo capítulo, será apresentado, o que realmente foi realizado pela CEMIG, por meio do material cedido pela FEAM, assim como pelas entrevistas realizadas na pesquisa de campo, a fim de fazer uma comparação com o que foi acordado e o realizado, e o quanto o status de realizado representou no investimento total da obra. 


\section{CAPÍTULO IV - O REALIZADO}

\subsection{Histórico das áreas para o reassentamento}

Como podemos observar, o reassentamento das famílias atingidas pelos empreendimentos hidrelétricos é um assunto muito polêmico, sendo com frequência questionadas a qualidade de compensação das terras do reassentamento e suas formas de indenização. Visando ao estudo dos “custos sociais”, o trabalho pretende fazer uma avaliação comparativa entre o acordado e o realizado pela população, dentro das condições citadas pelo empreendedor no TAC.

O Termo de Acordo firmado para indenização e realocação aos atingidos pela UHE de Irapé é um dos melhores acordos já realizados, quando falamos em direitos adquiridos pelos atingidos. No decorrer do capítulo, seguem alguns trechos das entrevistas que demonstram esta experiência.

Com base no material apresentado como "acordado", podemos afirmar que este tipo de empreendimento transforma, de forma abrupta, a região de sua área de influência, em razão da reconfiguração das bases sociais e econômicas locais, decorrentes do processo de expropriação e de atração de outros agentes

Com base no que vem acontecendo ao longo da história no Brasil, constata-se que as transformações sociais são particularmente acentuadas, o que resulta no empobrecimento das comunidades tradicionais.

Inicialmente, este trabalho era focado em apenas duas comunidades, Peixe Cru e Porto Coris. No decorrer da pesquisa e do trabalho de campo, pudemos observar que estas comunidades estavam sendo tratadas como "cenários", utilizadas pelo empreendedor para demonstrar suas boas ações. Certamente que, nestes locais, existem inúmeros problemas, porém tudo foi realizado, como previsto pela CEMIG.

A comunidade de Coris foi considerada como Quilombola - Comunidade Tradicional, e a outra por possuir características tradicionais do Vale do Jequitinhonha. A esse respeito sobre as comunidades, Mara Adelaide Pessoa Dutra (FEAM), assinala que:

[...] Porto Coris e Peixe Cru foram sempre consideradas as vitrines da CEMIG, porque era um dos lugares que ela mais investiu, um lugar que ela apresentava para os outros, porque que acontece normalmente os povoados ou cidades dão mais visibilidade. Elas chamam mais atenção, então, normalmente, esse povo é mais bem cuidados, Porto 
Coris, então, foi a maior vitrine porque era Quilombo, entendeu, tava todo mundo de olho: Fundação Palmares, IPHAN e tal. Tanto é que sempre que a CEMIG ia apresentar Irapé, ela apresentava Porto Coris e Peixe Cru e nós íamos para os outros e chegava e não acreditava não, é assim! Só esses dois estão assim (Entrevista Mara Adelaide Pessoa Dutra na sede da FEAM, 21/11/2008, Belo Horizonte, MG).

Como forma de confirmação deste depoimento, quando visitada a sede da CEMIG, os técnicos apresentaram um vídeo institucional a respeito dos reassentamentos onde figurava apenas a comunidade de Peixe Cru.

Portanto, julgamos conveniente não focar nessas comunidades. Com base no material colhido na pesquisa de campo (FEAM, Comissão de Atingidos, Cemig, Jornais, INCRA), tentaremos mostrar um pouco as dificuldades e como foram tratadas algumas das 47 comunidades atingidas. A partir deste direcionamento, mostraremos depoimentos sobre a questão do "realizado" pela CEMIG, e o que foi indenizado.

Quando os técnicos da FEAM apresentavam ao longo das vistorias a realidade que outras comunidades estavam sofrendo, a empresa - Cemig mostrava-se horrorizada com a notícia.

[...] aí mostrava Mandassaia, mostrava as cidades que estavam sofrendo a pressão das obras: Levivéldia, Virgem da Lapa, inclusive, problemas relacionados com a implantação do empreendimento e as áreas de reassentamento posteriormente (Entrevista Morel Queiroz da Costa Ribeiro, na sede da FEAM, 21/11/2008, Belo Horizonte, MG).

Mesmo com um cronograma para ser cumprido, a CEMIG não respeitou e acabou por atrasar as obras de reassentamento da população. De acordo com os representantes da CEMIG, a mesma autorizou que todos fossem indenizados.

todo atingido foi reconhecido pelos critérios ou do órgão ambiental ou do Ministério Público. Eles foram atendidos, independentes de ter ou não ter a documentação, tá? Porque muitos não tinham nem posse, eles não tinham nenhuma comprovação. Aí foi a posse, foi reconhecida, mediante declaração de vizinho, sindicato rural que ele ocupava aquela terra. Todos foram atendidos. O que aconteceu foi que algumas pessoas não se enquadravam nos critérios que quiseram ser incluídos, como beneficiários. E aí passou por uma análise da CEMIG e alguns casos foram recusados porque não tinha nada a ver (Entrevista Wilson Grossi, sede da CEMIG, 18/11/2008, Belo Horizonte, MG). 
Entretanto, a preocupação sobre o atraso no processo de reassentamento já teria sido apontado, a data limite para a implantação dos projetos executivos de relocação e reassentamento seria 31 de julho de 2004.

Por meio de um relatório elaborado pela FEAM, podemos perceber que a situação, 8 meses, após a data limite para o reassentamento das famílias, ainda era desesperadora. Cerca de $50 \%$ das casas ainda estavam em construção e 32\% ainda restavam ser construídas, assim como mostram os dados da tabela 4.1, com o cenário de construção dos reassentamentos, após a data limite estipulada pelo MPF.

Tabela 4. 1: Situação de construção do reassentamento

\begin{tabular}{ll}
\hline Cemig - situação em 23.03.2005 \\
\hline Total de casas necessárias & 493 \\
Total de casas construídas & $59(11,96 \%)$ \\
Total de casas em construção & $276(55,99 \%)$ \\
Total de casas a iniciar & $158(32,05 \%)$ \\
\hline \multicolumn{2}{c}{ Fonte: FEAM, Relatório, 2005, 1CD. }
\end{tabular}

É possível perceber o descaso da CEMIG com relação ao reassentamento das famílias que foram deslocadas pelo reservatório da Usina. Assim, a mídia local afirma os problemas encontrados pelos técnicos da FEAM.

nos sete municípios - Turmalina, Leme do Prado, José Gonçalves de Minas, Berilo, Cristália, Botumirim e Grão Mogol - que terão parcelas do território inundadas pelo lago. As dificuldades no processo de remanejamento da população são notórias. No fim da última semana, nenhuma família estava reassentada. Dezenas delas sequer sabiam para onde iriam. Em apenas duas das 90 áreas já adquiridas pela CEMIG, a construção das casas havia sido iniciada (JORNAL ESTADO DE MINAS, 22 ago. 2004).

Encontravam-se transferidas para as novas áreas de reassentamento apenas 59 famílias, o que correspondem a 9,25\% de um total de 638 famílias optantes pelo reassentamento. 
As residências definitivas novas são 19 famílias da comunidade quilombola de Porto Coris pela CEMIG para a Fazenda Mandassaia II, onde se observam: rede geral de energia e ligações domiciliares instaladas; sistema provisório de abastecimento de água, uma vez que o sistema definitivo encontra-se em fase de conclusão; problemas construtivos em moradias; edificações institucionais concluídas, mas ainda não em funcionamento; ausência de assistência técnica da EMATER; ausência de telefone. Parte dos pertences das famílias ainda permanecem na área de origem. Em fevereiro/2004, as terras não se encontravam preparadas para o plantio (FEAM, Conselho de Infraestrutura (CIF), 2005, 1CD).

Assim, das 59 casas que estavam construídas, 12 já passavam por problemas tanto na questão da qualidade das casas como no funcionamento das redes de água e preparação dos terrenos.

[...] 9 famílias da comunidade de José de Barros instaladas por conta própria na Fazenda Piedade: problemas construtivos em algumas moradias; abastecimento de água por caminhão-pipa; rede geral de energia e ligações domiciliares instaladas; escola encontra-se em reforma; sérios problemas de qualidade da terra em pelo menos 3 lotes. As criações ainda permanecem na área de origem (Relatório FEAM, Conselho de Infraestrutura (CIF), 2005, 1CD).

[...]3 famílias que se transferiram por conta própria a Fazenda Velho Texas - rede geral de energia e ligações domiciliares instaladas; sem abastecimento de água; terras para o plantio não preparadas; sem transporte ao centro urbano mais próximo; sem telefone (Relatório FEAM, Conselho de Infraestrutura (CIF), 2005, 1CD).

Em algumas fazendas adquiridas para os reassentamentos, já havia residências e toda a infraestrutura que o reassentamento demanda.

[...] 4 famílias da comunidade Malhada na Fazenda Sulbrasil possuía rede geral de energia e ligações domiciliares instaladas; água proveniente de poço já existente que, segundo os moradores, não é de boa qualidade; equipamentos de ensino e de saúde e serviços de telefonia já existentes, localizados próximo à área. Foi realizado o plantio de cultivos de subsistência (Relatório FEAM, Conselho de Infraestrutura (CIF), 2005). 
Já em outras, a realidade era um pouco diferente.

[...]1 família na fazenda São Mateus; em condição de moradia provisória em busca de condições para realização do plantio (Relatório FEAM, Conselho de Infraestrutura (CIF), 2005).

[...] barracas de plástico - fazendas Mumbuca, Boa Vista, Alvorada, Ferrador (Relatório FEAM, CIF, 2005)

Segundo Parecer Técnico DIENE (018/2005), com a expectativa para o enchimento do reservatório, grande parte das famílias foi transferida para as áreas de reassentamento que já apresentavam precárias condições para a instalação definitiva:

residências inacabadas, escolas, postos de saúde com obras paralisadas ou até concluídas mas não em funcionamento, ausência de transporte escolar, sistemas de abastecimento funcionando em condições insatisfatórias, acessos viários precários, ausência de serviços telefonia, terrenos não preparados frente à proximidade da época de plantio" (Parecer Técnico, 2005, p.5).

Observa-se conforme consta no Parecer, determinados casos foram corrigidos, após a instalação das famílias, mas outros persistiram.

Em diversas residências, foram constatados problemas construtivos como:

"entulho; trincas nas paredes e piso; mau fechamento de portas e janelas; estufamento de portas; goteiras; vazamento de pias; vasos; vazamento de caixas d'água interna com riscos a segurança das famílias; entupimentos da tubulação de água interna à casa; umidade por infiltração ascendente; instalação inadequada de serpentinas; dentre outros" (Parecer Técnico, 2005, p.5).

A qualidade das casas foi questionada em função de inúmeros problemas técnicos encontrados nos reassentamentos pelos técnicos da FEAM. A maioria das casas foi construída por empresas terceirizadas, contratadas pela CEMIG. Apenas um reassentamento com 12 casas foi realizado por meio da autogestão. Estes reassentamentos, em alguns lugares do País, geralmente, são exemplos de reassentamentos satisfatórios ou aqueles onde a população reassentada ficou mais satisfeita. Quando o reassentamento é construído dessa forma, além de utilizar material de ótima qualidade, os atingidos deixam a casa anterior e passam a habitar 
em outra, de acordo com sua preferência, e não em algo padronizado. No início, a CEMIG estava fazendo o acerto da indenização, sem conceder a terra de reassentamento.

Olha, nós tivemos vários problemas que se eu não tivesse acompanhado um pouco de perto, a coisa tinha dispenhado porque a CEMIG fez todos os acertos e não deu a terra pras pessoas. Só que tava pagando benfeitoria, aí o povo não tinha terra, não tinha casa, não tinha nada e saia aí com $\mathrm{R} \$ 20.000,00, \mathrm{R} \$ 30.000,00$ com $\mathrm{R} \$ 50.000,00$ no bolso. E aí quando ele recebia a terra ele não tinha nenhum centavo mais tem gente que sabe administrar tem gente que não sabe (Entrevista com Sr. José Antonio, Comissão dos Atingidos pela UHE de Irapé, 27/11/2008, Turmalina, MG).

O valor indenizado pela casa foi de $\mathrm{R} \$ 19.344,00$, e o tamanho, padronizado: todas possuem $64 \mathrm{~m}^{2}$. Muitas tiveram problemas, logo, com a construção civil. A janela foi construída próxima da porta, dificultando manter as duas abertas ao mesmo tempo, além de apresentarem rachaduras por utilizar material de baixa qualidade. Isso demanda uma manutenção por parte do novo proprietário, conforme evidenciam alguns depoimentos:

a construção das casas eles passavam para as empresas $\mathrm{R} \$ 19.344,00$ pra construção da casa, até isso a gente, o meu reassentamento foi um pouco diferente, porque a gente pediu o seguinte, nos não queremos que a CEMIG constrói nossa casa, nos que fazer.

a CEMIG ainda incentivava as pessoas, não só num faz isso não passa isso pra associação, a associação não dá conta de construir isso não, então teve gente que desistiu aí eu consegui construir umas doze a quatorze casas e aí construí a casa melhor. A casa que eles construíam o banheiro não tinha azulejo, eu coloquei.

fez do jeito que a pessoa queria.

e quando acabou a casa tudo arrumadinho, bonitinho eu devolvi para cada dono $\mathrm{R} \$ 2.300,00$.

a CEMIG foi fazer a canalização da rede de água e furou com a máquina o leme de estrada então agora não passava nada então nois carregava o cimento até na cabeça pra construção porque não passava o carro.

as casas que foram construídas pela Cemig teve muitos problemas, tem casa no meu reassentamento que foi desmanchada duas vezes, rachou toda, a empresa que construía era muito ruim, essa janela aqui ela colocava bem pertinho da porta, então quando abria a janela, 
janela de folha ela abria e tampava a porta, entendeu então as casas que eu fiz centralizei na parede, o material de má qualidade, instalação toda feia, um monte de fio bagunçado (Entrevista com Sr. José Antonio, Comissão dos Atingidos pela UHE de Irapé, 27/11/2008, Turmalina, MG).

Conforme relato do entrevistado, a CEMIG percebeu que a construtora não estava conseguindo concretizar o reassentamento dentro do prazo estipulado. Sendo assim, como o Sr. José Antonio havia construído de forma satisfatória as casas. A superintendente da CEMIG entrou em contato para que ele pudesse assumir o processo de construção do reassentamento.

eles contrataram a empresa para fazer um reassentamento umas casas lá eu construí umas 12 casa. E esse tempo de chuva, o cara tá lá, não constrói, não trabalha. Ele colocou tijolo, areia, cal e ta aquela confusão. Aí um dia, tava até surpreso, tava no escritório, aí ligou. Aí era a superintendente de Irapé, a Mônica, aí, a Monica falou comigo: Sr José tô ligando pra você que você construiu as casas e deu muito certo, então, eu queria que você pegasse aquelas casa daquela empresa lá, porque não sai. Eu falei Mônica, isso aí, eu acho que não dô conta disso. Não, fala isso, não. Eu tô doida prá acaba com aquele serviço e se o senhor não pega aquilo lá, não sai.

Eu falei uai, olha, eu vou conversar com o dono das casas, porque eu já tava já esgotado. Vou conversar com os donos das casas, e eu te dou um retorno. Mas, eu queria ver com ocê primeiro, tem casa lá que precisa só pôr a madeira em cima dela e dar o acabamento. Eu queria saber como que vai ser essa questão, porque você paga $\mathrm{R} \$ 19.344,00$ para construir uma casa. Esse cara já construiu a casa e falta pôr a madeira. Ela falou, olha esse é um problema meu com a empresa, eu vou te passar o $\mathrm{R} \$ 19.344,00$, para você construir a casa.

Se acredita, que eu fui nas casas, eu falei olha seis pega um pedreiro vai contrata e vai fazê a casa conserta, o que tem que conserta e tal.

Eles ficaram com preguiça, ficaram olhando o que ainda, se o cara gastou $\mathrm{R} \$ 10.000,00$ nela e terminou a casa ganhou $\mathrm{R} \$ 9.000,00$. Então tudo isso tem que ter administração (Entrevista com Sr. José Antonio, Comissão dos Atingidos pela UHE de Irapé, 27/11/2008, Turmalina, MG).

Alguns depoimentos evidenciam a qualidade das casas construídas para o reassentamento, muitas ainda passam por grandes problemas de manutenção. 
[...] uma coisa que aconteceu muito, foram a qualidade de algumas coisas que tiveram, por exemplo, em Posses. Eles já tinham planejado de fazer a ETE na porta da cozinha da casa, na verdade, a CEMIG não estavam fiscalizando o que estava sendo feito. Eles até tomaram isso como ofensa e tal, mas porque você via horrores. Você via casa sendo construída em barranco que ia desbarrancar (Entrevista Mara Adelaide Pessoa Dutra na sede da FEAM, 21/11/2008, Belo Horizonte, MG).

Seguem ilustrações de alguns problemas relacionados às casas, identificados por uma das vistorias da FEAM, em 2005:

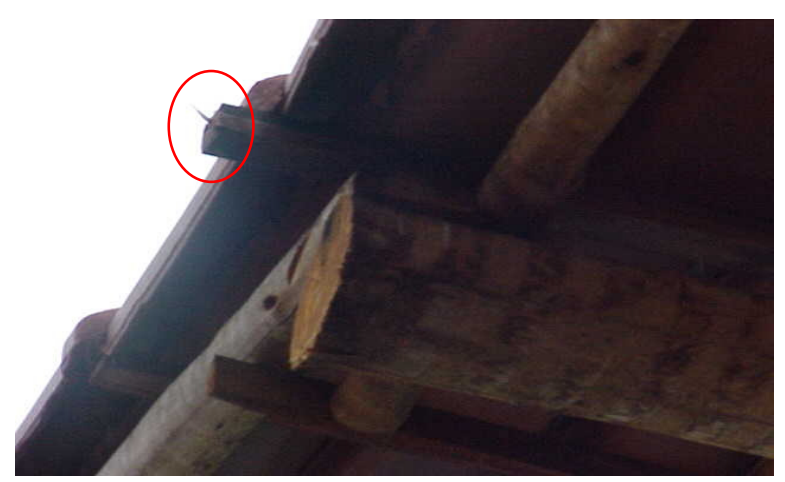

Figura 4.1 Gradeamento de telhado exposto, com comprometimento de sua durabilidade. Fonte: FEAM (2005, 1CD).

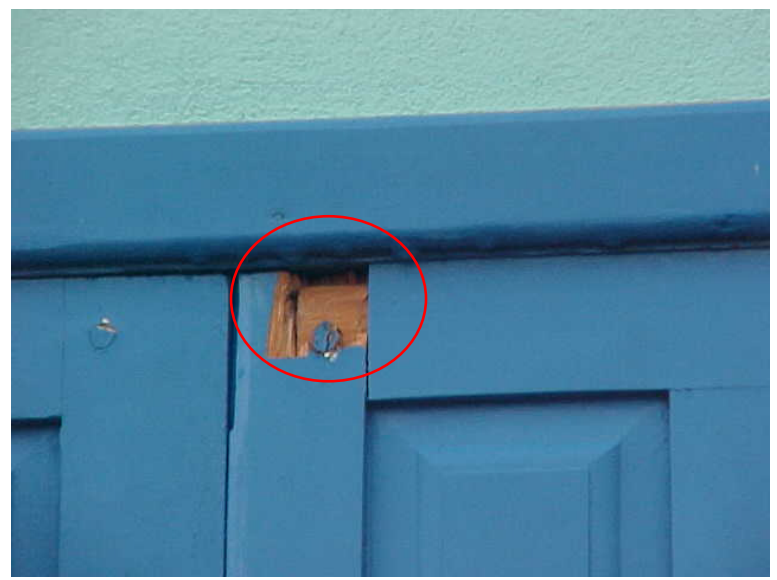

Figura 4.2 Casa da comunidade de Porto Coris. Janela danificada em razão do empenamento da madeira

Fonte: FEAM (2005, 1CD). 


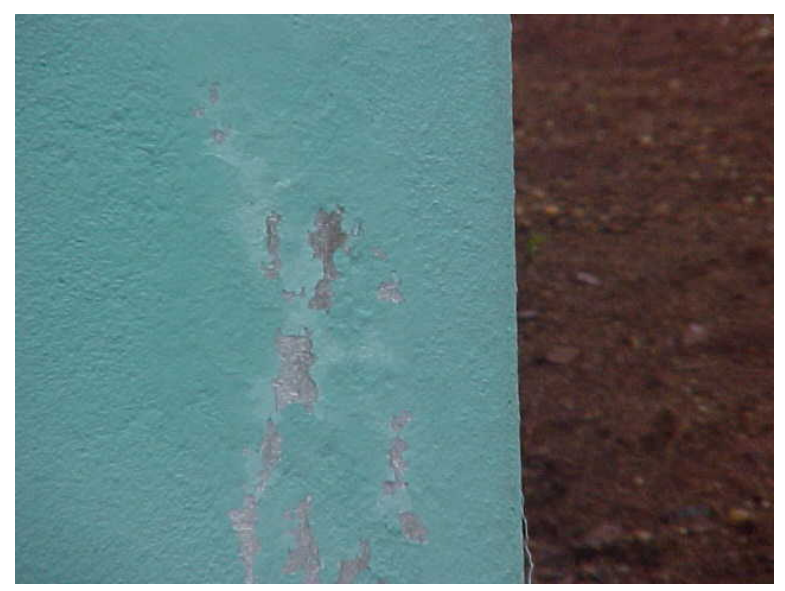

Figura 4.3 Parede pintada recentemente, já apresentando sinais de deterioração. Fonte: FEAM (2005, 1CD).

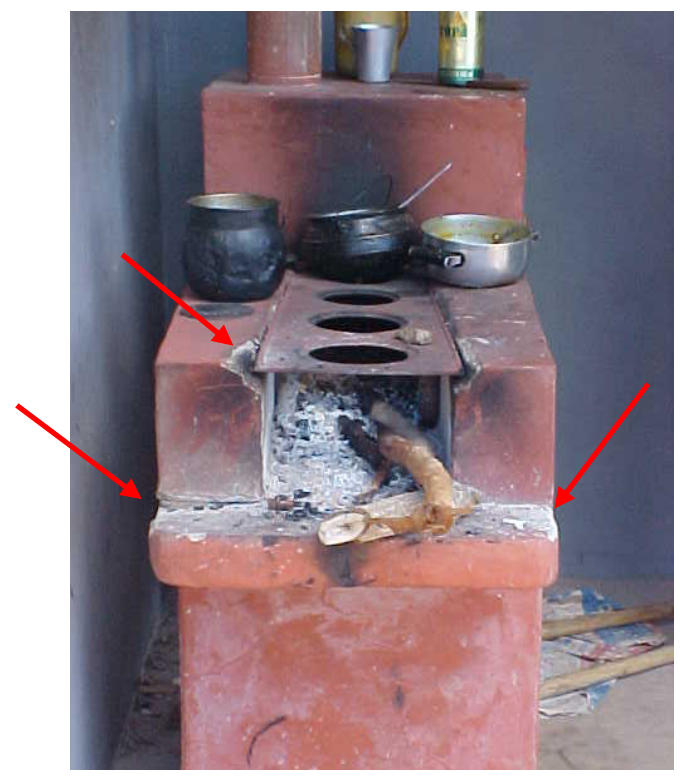

Figura 4.4 Fogão a lenha com aproximadamente, 15 dias de uso apresentando lasca e trincas.

Fonte: FEAM, anexo fotográfico, fevereiro de (2005, 1CD). 


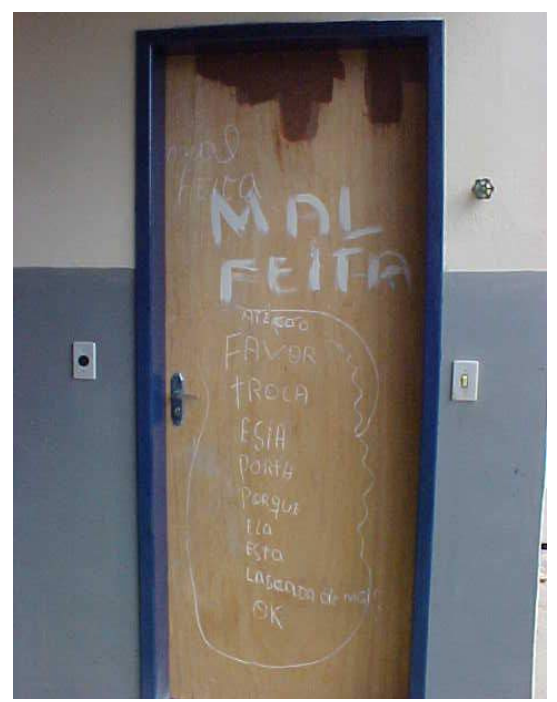

Figura 4.5 Porta com problema construtivo, motivo pelo qual D. Santa não mudou para a residência definitiva.

Fonte: FEAM, Anexo Relato Fotográfico (maio 2005).

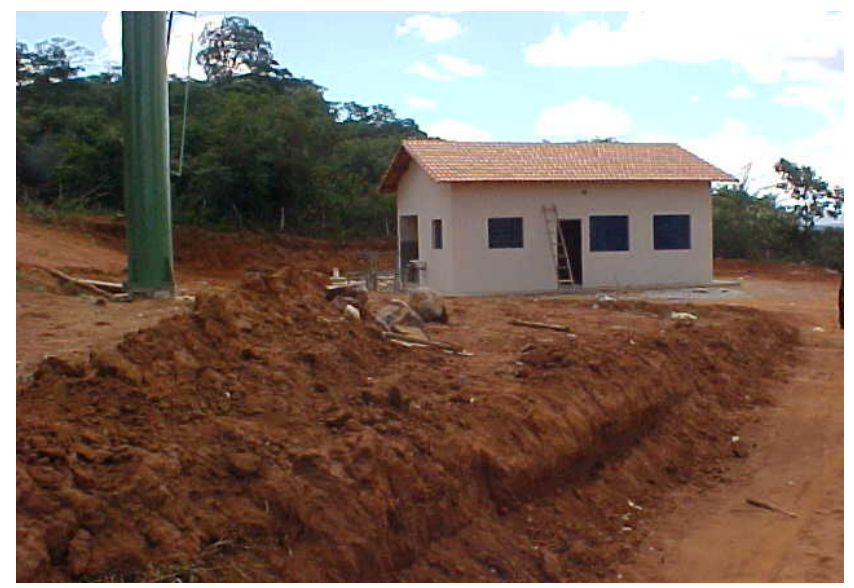

Figura 4.6 Primeira unidade residencial em construção na Fazenda Chácara. Fonte: FEAM, Anexo Relato Fotográfico (maio 2005).

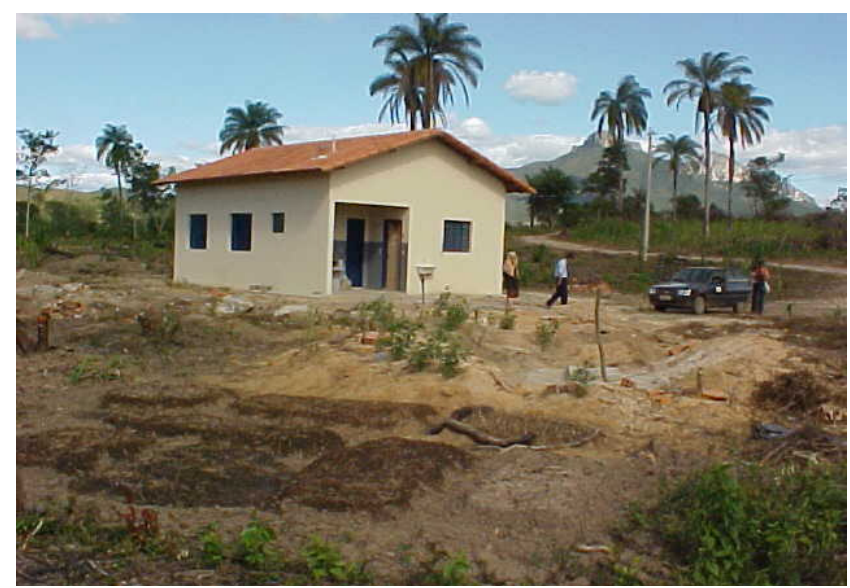

Figura 4.7 Futura residência de D. Santa, sua filha e 10 netos.

Fonte: FEAM, Anexo Relato Fotográfico (maio 2005). 
Na Figura 4.8, podemos observar que há uma grande diferença quanto ao tamanho e a disposição dos cômodos da casa de Dona Santa. A casa abaixo foi construída pelo próprio atingido. Os reassentamentos de autogestão em geral, têm uma grande diferença desde a qualidade da construção como também do projeto arquitetônico.

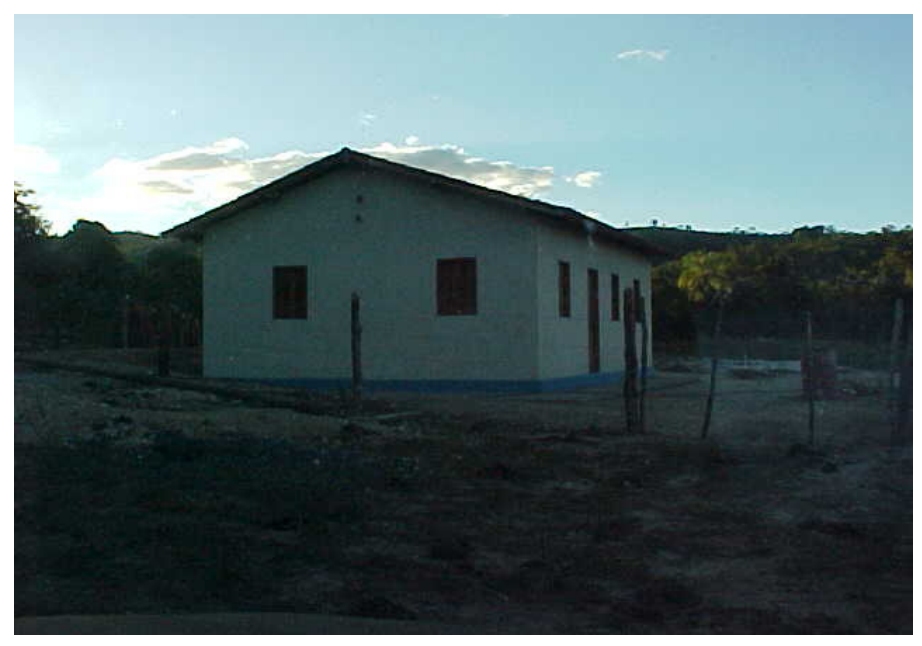

Figura 4.8 Casa na Fazenda Palhada (Autoconstrução).

Fonte: FEAM, Anexo Relato Fotográfico (maio 2005).

\subsection{Problemas com o ano letivo para as crianças}

Com base no acesso ao relatório completo da FEAM, é possível verificar que a todo momento os técnicos da FEAM buscavam sempre destacar, o que já havia sido solicitado no relatório anterior, para então utilizar como parâmetros no andamento do processo.

Uma das solicitações em caráter de urgência eram as medidas que garantiam o acesso à escola às crianças de comunidades a serem reassentadas.

O relato a essa Câmara, de 25 de fevereiro/2005, informou a ocorrência de situação bastante grave, em que, iniciado o ano letivo/2005, algumas comunidades a serem reassentadas estariam privadas de atendimento escolar, pois, os equipamentos existentes em suas áreas de origem já teriam sido desativados (e até mesmo demolidos) pelas prefeituras locais. Uma vez que essas tinham como certa a transferência das famílias para as áreas de reassentamento, antes do início do período letivo/2005. Essa situação estaria ocorrendo, pelo menos, nas comunidades de Bocaina, Carqueja e Ouro Podre (Relatório FEAM, Conselho de Infraestrutura (CIF), 2005). 
A CEMIG ${ }^{21}$ informou que as situações de atendimento escolar nas comunidades de Carqueja e Ouro Podre foram solucionadas, tendo a Prefeitura de Botumirim estendido o transporte escolar até essas comunidades. Em Bocaina (município de Turmalina), a escola não foi demolida e estava funcionando normalmente.

Em contrapartida, a resposta da CEMIG a mídia local relata a situação vivida pelas crianças.

a escola foi demolida em dezembro e as crianças da comunidade estão sendo submetidas a uma jornada de 12 horas, que inclui uma penosa caminhada em terreno íngreme, para assistir a 4 horas de aula a 25 quilômetros, no povoado de Santa Cruz. Várias mães não mandam os filhos para escola (Jornal Estado de Minas, 12 de abril de 2005).

No município de Cristália, o atendimento escolar foi retomado apenas no início de abril/2005, portanto, 2 meses, após o início do ano letivo.

Uma escola foi improvisada, em precárias instalações físicas (área de reassentamento de Gangorrinha); a escola reativada na comunidade de São Miguel fica a $3 \mathrm{~km}$ do local de moradia dos alunos; as famílias de São Miguel que se encontram em área de reassentamento de Janaúba permanecem sem atendimento escolar.

Dados da própria CEMIG atestam que, enquanto apenas 59 famílias haviam sido transferidas para áreas de reassentamento, 150 famílias realizaram o plantio nessas áreas. Verifica-se, portanto, que é significativo o número de famílias instaladas por conta própria nas áreas de destino e que estão sendo contabilizadas para efeito de avaliação da realização do plantio da safra 2004/2005, mas não para providências que lhes garantam o atendimento escolar.

Em contrapartida, a atingida Sra. Celuta do reassentamento União do Povo, a 14 km do município de Itamarandiba, relata a condição vivida, 3 anos após seu reassentamento.

As outras crianças que estudavam em José Gonçalves de Minas tinha o transporte, né? Aqui foi muito difícil, gente conseguir este transportes, mas mesmo assim, eles não vão até a casa das pessoas, as crianças precisam andar para pegar esse transporte, isso os que

${ }^{21}$ Reunião realizada em 07/03/2005, por determinação do Conselho de Infraestrutura de 25/02/2005, entre representantes desta, CEMIG, FEA e com a participação de representante do Ministério Público Federal, e em correspondência IR00183/2005, protocolada na FEAM em 21/03/2005. 
estudam na cidade, igual os que moram na Santa Quitéria, estudam aqui (Itamaramdiba) (Entrevista com atingida Sra. Celuta da Associação União do Povo, 25/11/2008, Itamarandiba, MG).

Os que moram na fazenda Cachoeira estudam em Aricanduva, ambas são longe e o que acontece, nessa época eles ficam sem aula, as estradas ficam intransitáveis e mesmo as escolas assim de primeiro grau né? Até a $4^{\circ}$ série, que eles prometeram reformar ou mesmo fazer dentro da comunidade, isso não aconteceu, nem postos de saúde, nem igreja, telefonia também que nós tínhamos lá, telefonia fixa. Colocaram um celular com antena que não funcionou, foi colocado, mas não teve funcionamento, ficaram de recolocar, mas acabou não recolocando (Entrevista com atingida Sra. Celuta da Associação União do Povo, 25/11/2008, Itamarandiba, MG).

Já para Sr. José Antonio, da Comissão dos Atingidos por Irapé, também reassentado, suas terras não aparentam problemas grandiosos, ele indica como problema maior a forma de negociação da comunidade com o empreendedor.

o meu reassentamento tem duas escola, duas fazendas, são 32 famílias, tem uma em uma fazenda e uma na outra (Entrevista Sr. José Antonio, Comissão dos Atingidos por Irapé, 27/11/2008, Turmalina, $\mathrm{MG})$.

Em resposta, os representantes da CEMIG argumentam que a responsabilidade em dar continuidade à prestação de serviço é do município, que a CEMIG "infelizmente, não tem esta função" (Entrevista Wilson Grossi, sede da CEMIG, 18/11/2008, Belo Horizonte, MG).

Os representantes da CEMIG foram questionados quanto ao andamento das funções básicas como, postos de saúde, escolas, postos de telefonia, foram obtidas as seguintes respostas:

[...] a CEMIG constrói e repassa para a prefeitura gerenciar até porque esta função de educação, saúde como a segurança é do Estado (Entrevista Wilson Grossi, sede da CEMIG, 18/11/2008, Belo Horizonte, MG).

A nossa parte é permitir "dar o enxoval" o posto de saúde recebe equipado, conforme a FUNASA determina. A escola é equipada, conforme a Secretaria Estadual de Educação determinou, mas o professor é com o Município e Estado, porque as funções institucionais são outras (Entrevista Guilherme Comitti, sede da CEMIG, 18/11/2008, Belo Horizonte, MG). 
Quando questionados conheciam o andamento dos serviços nos locais de reassentamento, responderam que assegurar estes itens à população é de responsabilidade do Município e do Estado.

[...] alguns sim outros não" tem mais política do que outra coisa no meio. Uma vez nós tivemos uma mudança e teve uma eleição, em 2006. Hoje, prefeitos que retomaram querem renegociar, que contestam, que não querem assumir. Tipo assim, o que o outro prefeito fez, eu não concordo, não faço. Aí é Brasil (Entrevista Guilherme Comitti, sede da CEMIG, 18/11/2008, Belo Horizonte, $\mathrm{MG})$.

vou te dar dois exemplos só pra você ver, tinha uma demanda no município de Cristália sobre o valor das escolas. A CEMIG tinha avaliado um valor de 102 mil reais e a prefeitura contestou o valor e pediu 800 mil. Aí CEMIG não concordou e foi para a justiça, a questão do valor. Aí recentemente o prefeito está saindo, deixando o cargo agora segunda eleição dele, não pode voltar. Ele quer encerrar o mandato dele, então, ele propôs um acordo pra CEMIG reduzindo o valor tinha estimado lá para fechar um acordo para a CEMIG concordar com o valor, para ele aplicar numa obra de educação que ele tá querendo lá. Então, se vê, ficou 4 anos na contestação e chegou no final do mandato dele, por interesse dele, ele se interessou (Entrevista Wilson Grossi, sede da CEMIG, 18/11/2008, Belo Horizonte, MG).

um outro caso é o seguinte: algumas escolas, né? E parte de uma determinada das crianças foram para determinada escola e a CEMIG. O transporte escolar era feito por caminhão, com carroceria e a CEMIG para estas escolas que foram afetadas com o aporte de gente, do reassentamento a CEMIG comprou quatro ônibus e doou para a prefeitura para fazer o transporte escolar. O prefeito tava economizando os ônibus, entendeu e usando em alguns casos os mesmos caminhões" (Entrevista Wilson Grossi, sede da CEMIG, 18/11/2008, Belo Horizonte, MG).

não podemos garantir que tudo esteja funcionando como a gente gostaria (Entrevista Guilherme Comitti, sede da CEMIG, 18/11/2008, Belo Horizonte, MG).

Conforme Parecer Técnico (2005) o cenário com relação às escolas era: três escolas em funcionamento (Faz. Gangorrinha, Riacho da Porta e Mandassaia); três concluídas sem funcionar: (Faz. Dalas, Conjunto Rib. Vermelho e Araras) e três obras paralisadas (Faz. Santa Cruz, Barreiro/Gurita e Muquém, Cristália). 


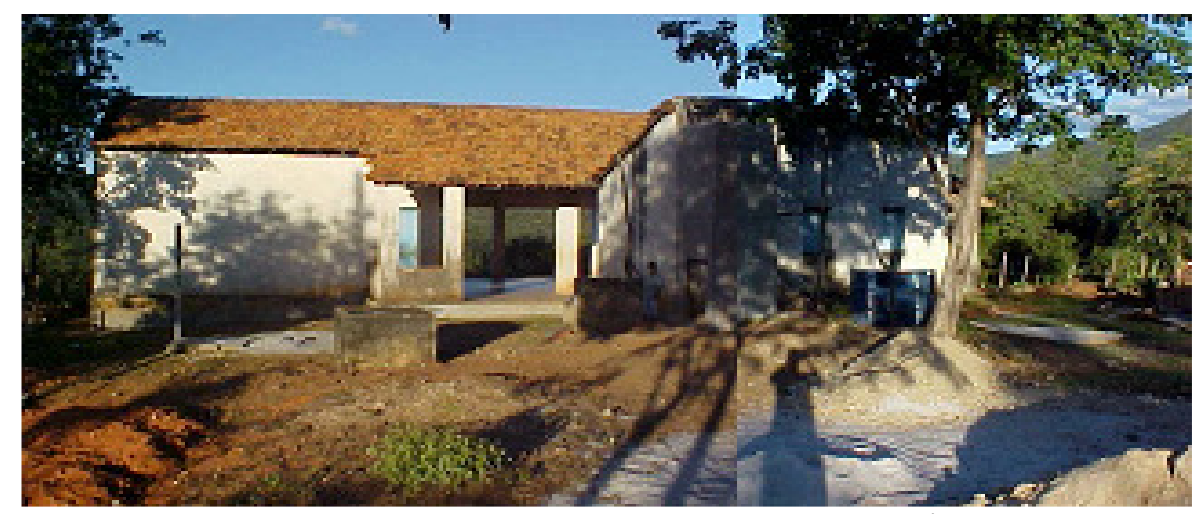

Figura 4.9 Escola Municipal Juscelino Rodrigues - Cristália, em reforma. Fonte: FEAM, Anexo Relato Fotográfico (maio 2005).

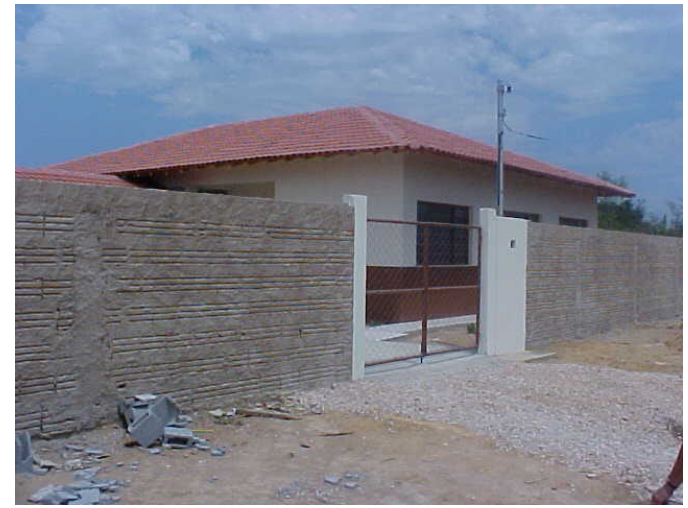

Figura 4.10 Escola do reassentamento, ainda não estava em funcionamento, os equipamentos já estão instalados, mas a fossa não tinha sido concluída e falta professor. Crianças estão sem aulas desde a transferência para a área (de 15 dias a 1 mês).

Fonte: FEAM, Anexo Fotográfico Vistoria (19 a 25 setembro, 2005).

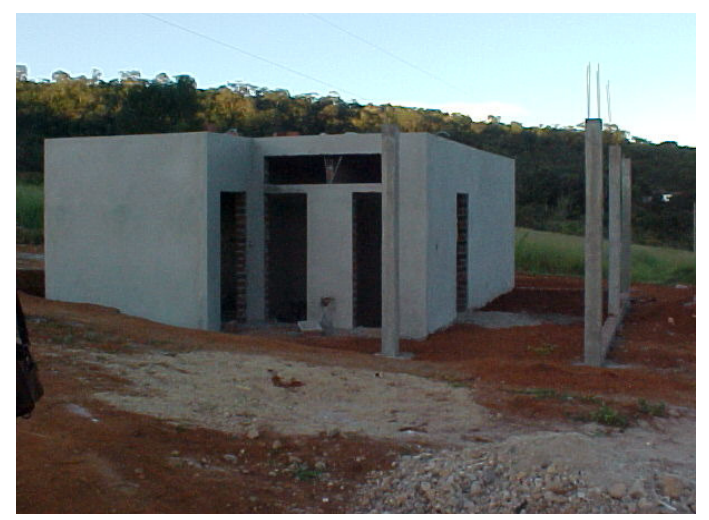

Figura. 4.11 Escola em construção na Fazenda Camargo.

Fonte: FEAM, Anexo Fotográfico (maio, 2005). 


\subsection{Avaliação das condições para realização do plantio da safra nas áreas de}

destino (Reassentamento) e da necessidade de serem destinadas medidas compensatórias às famílias

$\mathrm{Na}$ reunião em 01/04/2005, a CEMIG informou verbalmente que estava encaminhando proposta ao Ministério Público Federal de agregação de um valor à da Verba de Manutenção dos reassentamentos (estabelecida no Termo de Acordo), de forma a compensar os atingidos pelo comprometimento da perda da safra 2004/2005, decorrente da inexistência ou incipiência de condições, para a realização do plantio verificadas, tanto nas áreas de origem como de destino da população afetada.

A FEAM não pode se manifestar sobre essa proposta, na medida que não dispõe de maiores informações sobre seu conteúdo. Observa-se que, quanto à Verba de Manutenção, o Termo de Acordo (Anexo I, item 8), dispõe que “o valor cabível a cada reassentamento será repassado no início da implantação do projeto de reassentamento. O repasse só será efetuado após a constituição da respectiva associação".

Conforme depoimento da atingida Sra. Celuta, da Associação União do Povo:

Antes do término da casa, eles falaram que nós tínhamos que assumir, então, teve uma época que nós estávamos morando em cinco famílias na casa sede, que tinha uma casa sede na fazenda, tanto na Santa Quitéria quanto na Fazenda Cachoeira Bartolomeu. Todas tinha casas não boa, mas grandes. Então, foi mudado as famílias morávamos em cinco famílias tudo junto, e era longe para ir da sede para nossos terrenos trabalhar. Então por isso, as mudas perderam. A gente ficou pra traz de quem recebeu a casa no tempo, não tem quintal formado ainda. Até hoje, não conseguimos estruturar, mesmo porque a água também que eles falaram que seria, teríamos torneira dentro de casa essa coisa toda é eles, pra quem não teve direito a casa, eles deixaram mais de quinhentos metros da casa. Nos construímos um barraco e mesmo assim eles não colocaram água (Entrevista com atingida Sra. Celuta da Associação União do Povo, 25/11/2008, Itamarandiba, $\mathrm{MG})$.

Durante a entrevista, perguntamos à Sra. Celuta, como estava sendo viver nessa nova terra, ao que ela nos respondeu: 
continua difícil né? A terra é considerado uma terra boa, só que veja bem, lá nós em José Gonçalves de Minas, onde nós morávamos nos nunca usamos produto químico nem calcário, nem nada. Aqui teve que usar. Foi prometido colocar esse calcário, não foi colocado. É, foi prometido, eles desmatarem cinco hectares por ano. Isso não aconteceu. Aconteceu assim, os cinco primeiros cinco hectares não na época correta eles fizeram né? Mas, a colocação de calcário, até compraram calcário mas deixaram lá no meio do pasto lá no meio da estrada, E não foi colocado nas terras, então, assim pra gente que não tava acostumado a usar adubo, usar nada químico, assim, é a gente teve dificuldade nunca tinha usado nem conhecia esses produtos químicos, né? Aqui pra produzir tem que usar. Eu assim mesmo tô super atrasada porque sou contra usar produtos químicos né. Então tô tentando orgânico, então, tá super difícil de conseguir, então, não é considerado assim uma terra boa (Entrevista com atingida Sra. Celuta da Associação União do Povo, 25/11/2008, Itamarandiba, MG).

O Sr. José Antonio relata que a CEMIG na questão de produção, só forneceu mudas, semente e adubo para o primeiro plantio.

Pelos relatórios e pesquisas, percebemos que a maioria das terras escolhidas para o reassentamento são terras que precisam de nutrientes, como citado pela atingida Sra. Celuta. Para isso, além do dinheiro para compra desse material, é preciso um meio de transporte, o que ocasiona um custo para o reassentamento.

Algumas famílias reassentadas foram privilegiadas e mudaram-se para uma terra boa, próxima aos centros urbanos, como é o caso do Sr. José Antonio, da Comissão dos Atingidos pela UHE de Irapé. Mas, a grande maioria acabou reassentada em terras distantes dos centros urbanos e com uma qualidade muito ruim de solo.

Contudo, os técnicos da FEAM afirmam que as terras onde está localizado o reassentamento do Sr. José Antonio, foi um reassentamento que deu certo. 


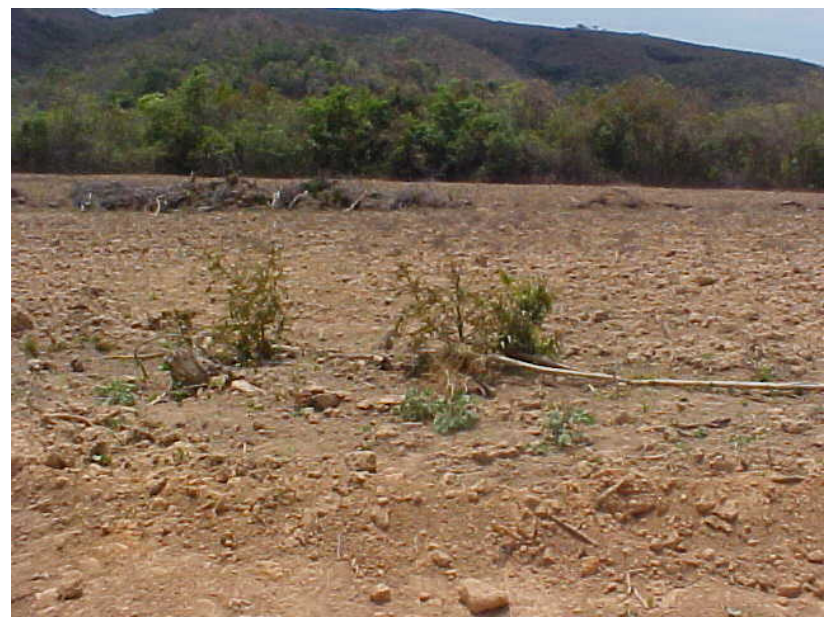

Figura 4.12 Terreno para plantio sem a devida preparação (calagem), rebrota de vegetação e presença de leiras. - lote 12, Faz. Riacho da Porta.

Fonte: FEAM, Anexo Fotográfico Vistoria (19 a 25 setembro, 2005).

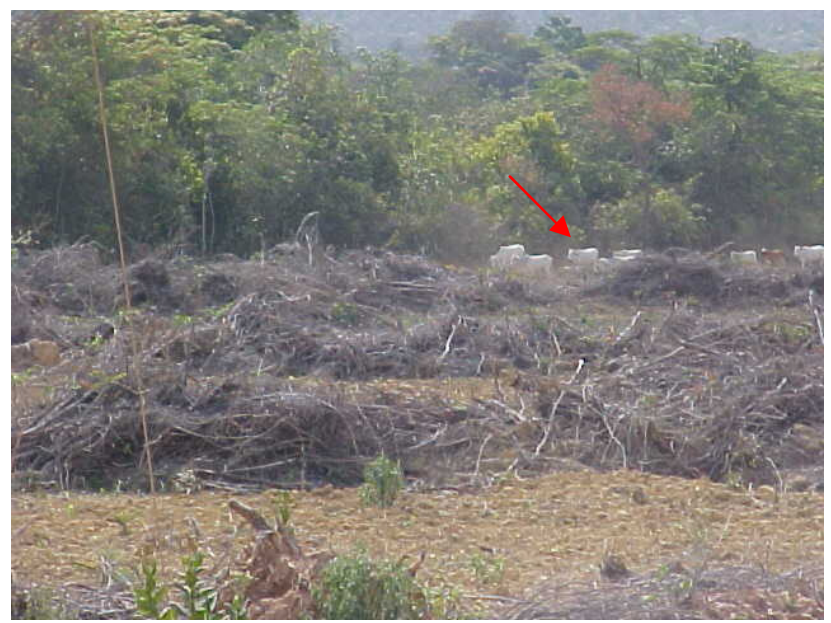

Figura 4.13 Presença de gado da fazenda vizinha, devido à falta de cercamento dos lotes. As áreas de plantio estão cobertas de leiras, dificultando o preparo da área.

Fonte: FEAM, Anexo Fotográfico Vistoria (19 a 25 setembro, 2005).

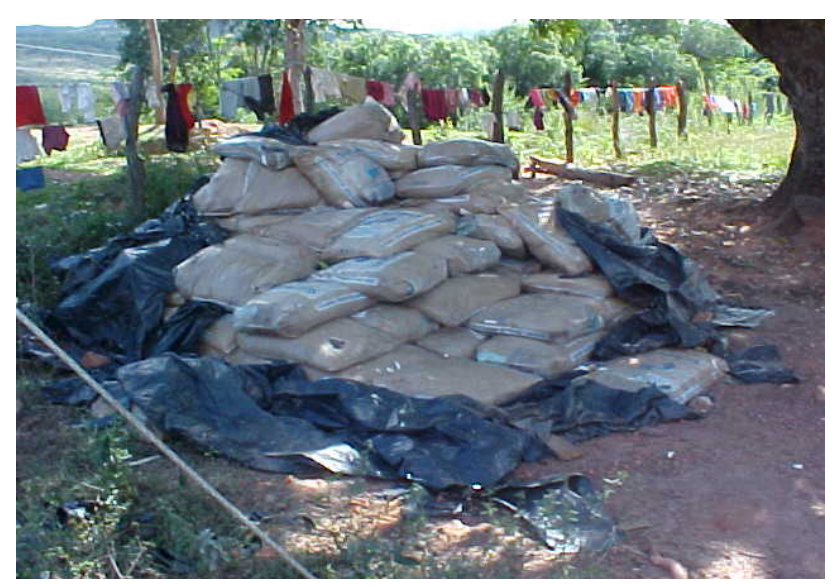

Figura 4.14 Adubos armazenados em local inadequada - situação já relatada em fev/05.

Fonte: FEAM, Anexo Fotográfico (maio 2005). 


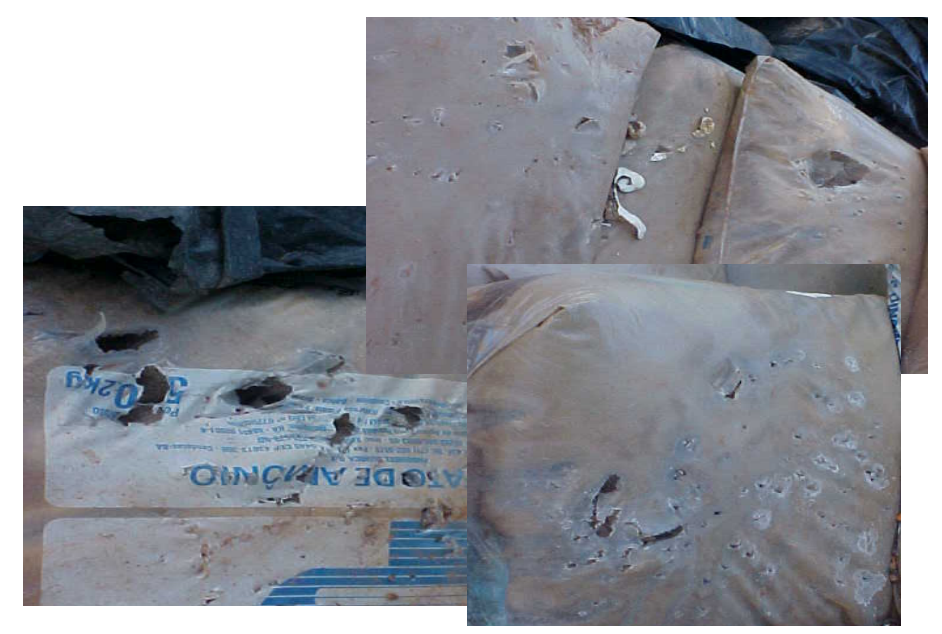

Figura 4.15 Vista em detalhe da sacaria rasgada, comprometendo a qualidade do adubo.

Fonte: FEAM, Anexo Fotográfico (maio 2005).

Como pudemos acompanhar pelas fotos, com relação aos incentivos para a safra, conforme acordado, em 2002, a empresa CEMIG comprometeu-se a fornecer todos os subsídios, como mudas, sementes para o plantio da primeira safra nos reassentamentos, porém estas mesmas não foram entregues no tempo certo, e os reassentados foram prejudicados.

[...] aconteceu muito, eles distribuírem calcário, muda na época que o pessoal ainda não tinha mudado (Entrevista Mara Adelaide Pessoa Dutra na sede da FEAM (21/11/2008).

Muitos reassentados não tomaram posse na época do plantio por falta da infraestrutura no local, o que acabou ocasionando a perda das mudas e sementes, não era possível ir até a propriedade para cuidar da terra, o que culminou no prejuízo de inúmeras sacas de calcário.

\subsection{Abastecimento de água nas áreas de reassentamento}

Um dos maiores problemas nas áreas de reassentamento é o acesso à água. As chapadas não possuem água de qualidade, os córregos mais próximos, muitas vezes, foram secos pela floresta de eucalipto e a água que a CEMIG instalou, é bombeada para as casas, o que demanda uma grande quantidade de energia.

Algumas fazendas ainda são abastecidas por caminhões pipas, "Os moradores desconhecem a origem da água e já ficaram 15 dias sem abastecimento" (Relatório FEAM, 2005). 
Em todas as fazendas, foram instaladas caixas d'água no ao local de cada moradia, muitas abastecidas por caminhão-pipa e destinadas a fornecer água para as obras de construção das moradias. Normalmente, a água é captada no curso mais próximo à área de reassentamento.

No entanto, em fevereiro de 2007, pela reportagem do jornalista Bernardino Furtado (Jornal Estado de Minas, 11/02/2007) é relatado que as comunidades atingidas pela barragem enfrentam escassez de água. O motivo são as altas contas de energia emitidas pela CEMIG, para cobrar o consumo das bombas que abastecem as casas dos reassentados.

Em algumas fazendas, como a Fazenda Dileta, em José Gonçalves de Minas, e a Fazenda Mandassaia, em Leme do Prado, a empresa cortou o fornecimento de energia, pois os consumidores estavam inadimplentes. À beira do Rio, as famílias não possuíam energia elétrica, hoje, a empresa conectou as casas dos reassentamentos à rede, porém as famílias não possuem renda o suficiente para arcar com as novas despesas.

Antes da hidrelétrica, vivíamos nas barrancas do Rio Jequitinhonha. Cada casa tinha a sua água limpa, encanada de nascentes, por gravidade, sem precisão da energia (Jornal Estado de Minas, "Famílias estão sem água e endividadas", 11/02/2007, moradora do reassentamento Nova Bela Vista).

As contas de energia das bombas instaladas pela CEMIG para puxar água dos poços ou para bombear água dos rios da associação dos Reassentados de Nova Bela Vista, foram de aproximadamente, $\mathrm{R} \$ 1,7$ mil em 2007 . O rateio é de $\mathrm{R} \$ 60,00$ por família.

Não dá para pagar. A única renda garantida aqui é a Bolsa Família, R\$ 75, por mês (Jornal Estado de Minas, "Famílias estão sem água e endividadas", 11/02/2007, moradora do reassentamento Nova Bela Vista).

Em resposta a esta reportagem, a CEMIG informou que em parceria com a EMATER iriam buscar alternativas para o abastecimento de água, visto que, por ocasião das visitas em novembro de 2008, as famílias estavam inadimplentes, conforme depoimento do Sr. Antonio:

A Cemig, recentemente, deu pra nós um ano de energia e bombeamento de água, pra todas as comunidades, uma coisa meio esquisito, mas tá, eles começam a cobrar em março de 2009. 
Em Janaúba, distante $200 \mathrm{~km}$ da cidade de origem, os reassentamentos na Fazenda Muquém, estão satisfeitos com a terra, porém o problema maior é o acesso à água, anteriormente gratuito, uma vez que o rio estava ali.

O reassentamento já perdeu as contas de quantas vezes já trocou a tubulação. A água é muito alcalina e entope rapidamente os tubos, além de ser imprópria para beber (Jornal Estado de Minas, "Lago no Deserto", 31/08/2008).

Como podemos observar, em função das reportagens descritas (ANEXO), um dos maiores problemas é o acesso à água, eles dependem da água para a agricultura e para a sobrevivência natural do homem.

Um dos principais problemas apontados no Parecer Técnico é com relação ao abastecimento de água e saneamento básico. Segundo Parecer, a situação em 2005 era a seguinte: "reservatórios externos individuais de água ainda não implantadas; frequentes rompimentos da rede de distribuição de água; ausência de drenagem pluvial; de esgotamento do sistema de limpeza; áreas degradadas não recuperadas, água apresentando visualmente cor e turbidez; nas Fazendas Araras e Muquém não foram implantadas unidade de filtração (cálcio) na água, escassez no período seco; e já, em 2005, existia a preocupação das famílias com os custos elevados de energia com o bombeamento.

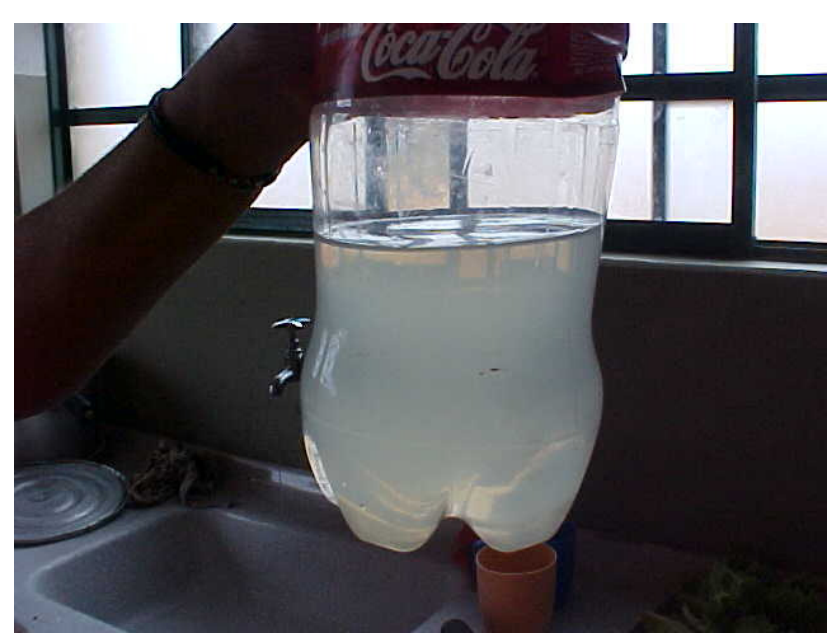

Figura 4.16 Água com aspecto turvo. Já em 2005 moradores reclamavam do cheiro e da cor da água.

Fonte: Fonte: FEAM, Anexo Fotográfico Vistoria (19 a 25 setembro, 2005). 


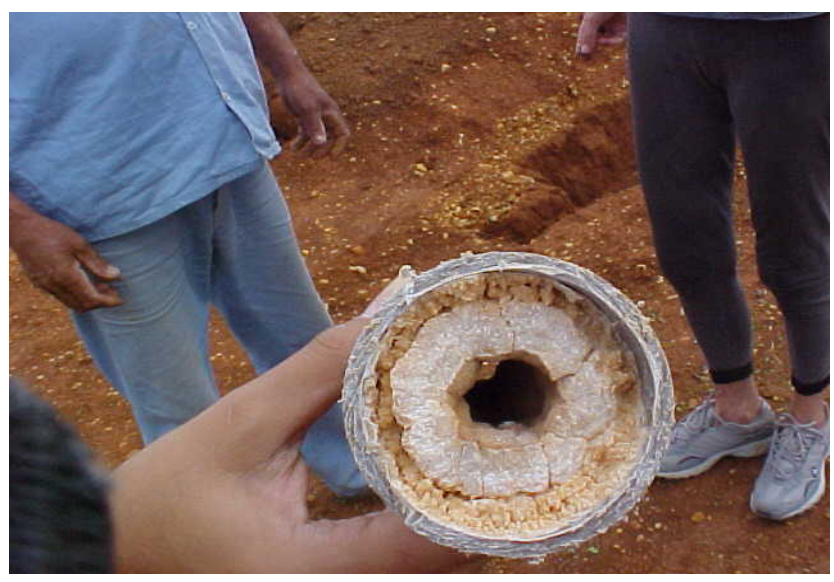

Figura 4.17 Tubulação com encrustamento em vez do teor elevado de cálcio (água cálcarea), Fazenda Muquém.

Fonte: Fonte: FEAM, Anexo Fotográfico Vistoria (19 a 25 setembro, 2005).

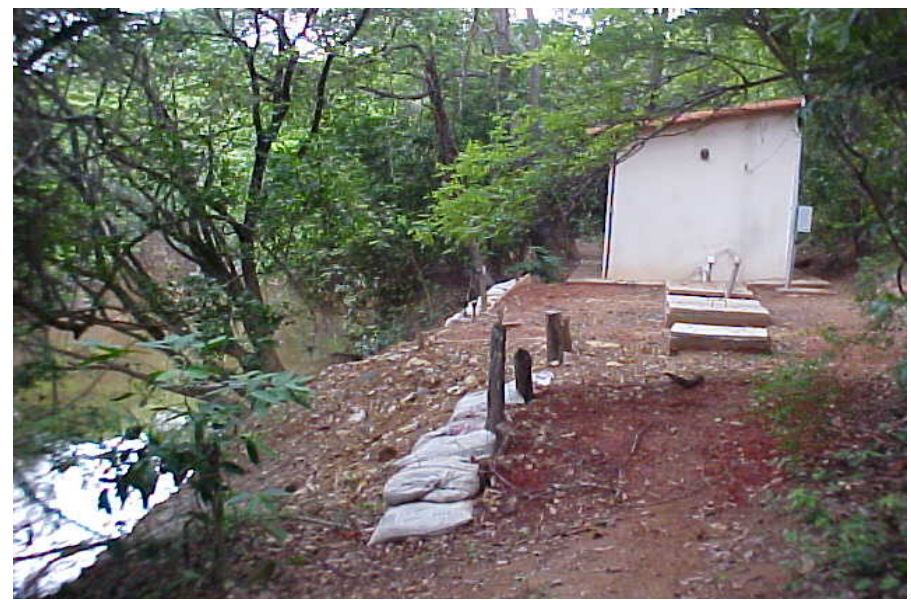

Figura 4. 18 Sistema de Captação e elevatória de água bruta (casa de bombas), Fazenda Rio Preto.

Fonte: Fonte: FEAM, Anexo Fotográfico Vistoria (19 a 25 setembro, 2005).

\subsection{Qualidade das terras adquiridas}

Com referência à qualidade das terras nos reassentamentos, a pesquisa de campo levantou três opiniões divergentes.

Portanto, podemos ter uma base das condições que o empreendedor comprometeu-se e o que foi concretizado. As condições anteriores ao reassentamento eram muito difíceis como relata Sr. José Antônio:

Lá, onde eu morava na beira do Jequitinhonha, não tinha estrada, lá nos não tinha energia. Nós não tinha água encanada, nós não tinha banheiro em casa nós não tinha casa de qualidade. Então lá (reassentamento) temo um acesso muito bom umas terras superiores às nossas que nós temos na beira do Jequitinhonha, nós temos uma casa boa, água encanada não é de muita qualidade não. Mas, a gente 
vai se ajeitando, casa com banheiro, energia, a gente consegue produzir muito a produção é muito boa. Nos tivemos uma verba de manutenção que foi uma briga que eu tive com a CEMIG e Secretaria Ambiental então a CEMIG depositou na conta de cada associação, Após que a gente mudo um total de, foi mais ou menos um total de $\mathrm{R} \$$ 4.250,00 por família, então, 20 família (Entrevista Sr. José Antonio, Comissão dos Atingidos por Irapé, 27/11/2008, Turmalina, MG)

Conforme entrevista gravada, o Sr. Wilson Grossi afirma que o empreendedor, "adquiriu cerca de 60.000 hectares para uma área de reservatório de 137 km²" (Entrevista com Wilson Grossi, na sede da CEMIG, 18/11/2008, Belo Horizonte, MG).

Outra atingida foi indenizada por ser herdeira, com um módulo fiscal e meio e declara que na propriedade adquirida para o reassentamento

Só terra, só pastagens num peguei nada assim um pé de fruta. Teve alguns que tiveram sorte assim de pegar já pomar formados, né? (Entrevista com atingida Sra. Celuta da Associação União do Povo, 25/11/2008, Itamarandiba, MG).

Conforme o Termo de Acordo, as famílias tiveram a opção de escolher o local para o reassentamento, contudo houve comunidades que a Comissão de Atingidos pela UHE de Irapé não conseguiu acompanhar para orientar, o que acabou culminando em uma escolha errônea e tornou-se impossível voltar atrás, além da pressão em função do tempo, pois a CEMIG deixou tudo para os últimos momentos. Existia também uma forte preocupação em relação ao município de origem das comunidades:

As características todas são iguais, é um pessoal que morava lá naquelas condição que eu ti falei: sem energia, sem água encanada, sem casa boa. Vivia da produção, mesmo a situação assim era meio difícil, mas aí teve uma outra coisa, porque nós tivemos é garantia dentro do Termo de Acordo que a gente poderia tá escolhendo uma terra de qualidade, de classificação boa e a pessoa conheceria essa terra e a questão é tão grande que a gente não deu conta de acompanhar cada caso, então, teve um família que pego terra que no lugar que não produz nada. Tudo por falta de conhecimento, terra que não tem água e prova que tanto, muita gente tá vendendo os lote (Entrevista com Sr. José Antonio, Comissão de Atingidos pela UHE de Irapé, 27/11/2008, Turmalina, MG).

Inclusive, Peixe Cru saiu da margem do Jequitinhonha, da margem e veio pra dentro do paião de eucalipto onde produz só eucalipto. A terra num presta e aí tem outra coisa houve aquela questão, assim, eu 
escolhi uma terra lá em Itamarandiba e vou sair daqui do município. Amanhã, ou depois a prefeitura os vereador sabia disso aí ia todo mundo pra lá. Quando chegava lá, eles não o que que isso nós vamo ageita a terra pro seis no município, que a prefeitura vai investir, que a prefeitura vai fazer isso, aquilo vai dar apoio e tal (Entrevista com Sr. José Antonio, Comissão de Atingidos pela UHE de Irapé, 27/11/2008, Turmalina, MG).

Aí, as pessoas com medo de sair lá pra fora, com medo de uma situação compricada porque já conhecia todo mundo aqui acabava ficando. E ela mesmo acabava ficando (Entrevista com Sr. José Antonio, Comissão de Atingidos pela UHE de Irapé, 27/11/2008, Turmalina, MG).

A comunidade Peixe Cru sofre as consequências até hoje. A opção pela área de reassentamento foi exclusivamente dela; os atingidos optaram por continuar dentro do mesmo município, contudo acabaram ficando com uma terra ruim, que não produz. A grande maioria das pessoas já vendeu seus lotes para tentar a vida na cidade.

O número de famílias que fizeram a opção pelo reassentamento é de 638, em 17 municípios, em 103 propriedades espalhadas pelo Estado de Minas Gerais.

A Figura 4.1 indica as principais áreas de abrangência dos reassentamentos, e dá para se ter uma ideia da distância do reassentamento de algumas famílias das margens do Rio Jequitinhonha.

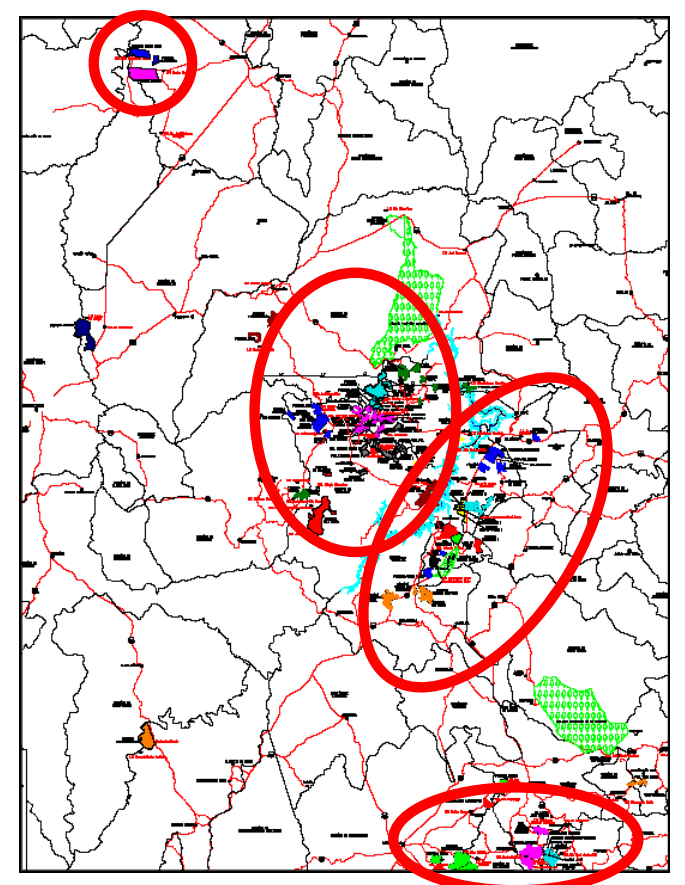

Figura 4.19:Áreas selecionadas para os reassentamentos UHE Irapé Fonte: CEMIG, Apresentação PUC Minas Gerais (2006). 
As áreas demarcadas com círculos são as de concentração dos reassentamentos, podemos observar com maior clareza a grandiosidade das 103 propriedades adquiridas para o reassentamento.

Os atingidos foram realocados em 17 municípios da região: Leme do Prado/MG, Diamantina/MG, Água Boa, Francisco de Sá, José Gonçalves de Minas, Janaúba, Botumirim, Turmalina, Itacambira, Itamarandiba, Capelinha, Montes Claros, Grão Mogol, Angelandia, Cristália Francisco Dumont e Berilo.

Muitos municípios no entorno da UHE não possuíam terras com boa classificação para a realocação das famílias, muitas vezes em função das empresas de reflorestamento que predominam na paisagem da região.

Turmalina não tinha condição de reassentar ninguém, não tem terra. Todas as terras aqui as empresas de reflorestamento tomo. Elas não prestam para desenvolver agricultura, então, eu sabia disso. Em todo os meu depoimento, eu colocava isso, não tem condição, mas só que o prefeito tava que ia sai 80, 100 famílias do município dele. Aí virava um jogo de disputa mesmo, né? E aí tem aquelas pessoa que não vai (Entrevista com Sr. José Antonio, Comissão dos Atingidos pela UHE de Irapé (27/11/2008).

Seguem algumas fotos das áreas escolhidas para o reassentamento:

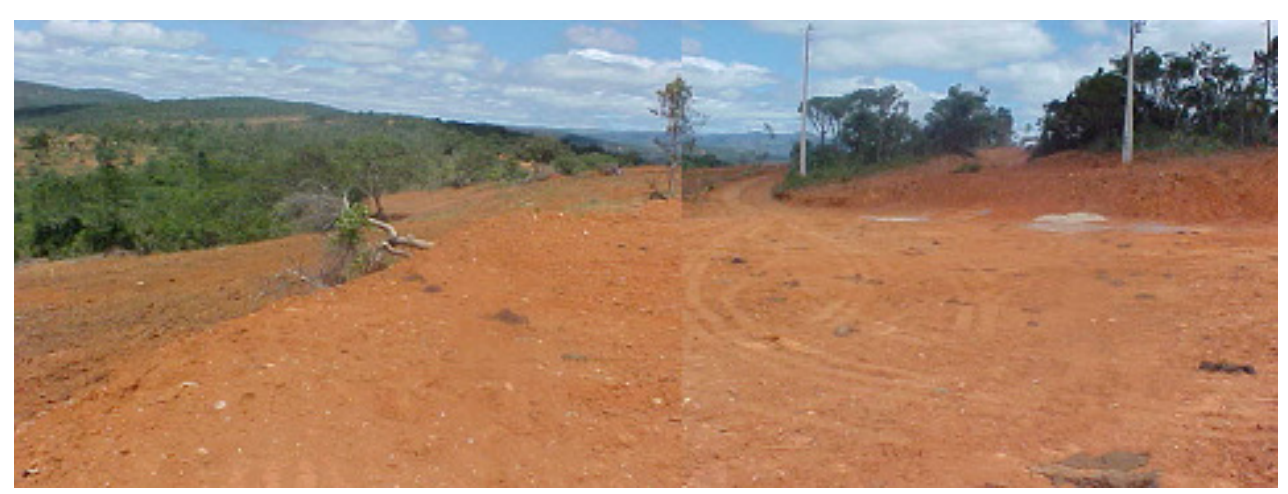

Figura 4.20 - Área destinada a construção de casa e área de plantio recém-preparada (Fazenda Planalto)

Fonte: FEAM, Anexo Fotográfico (abril 2005). 


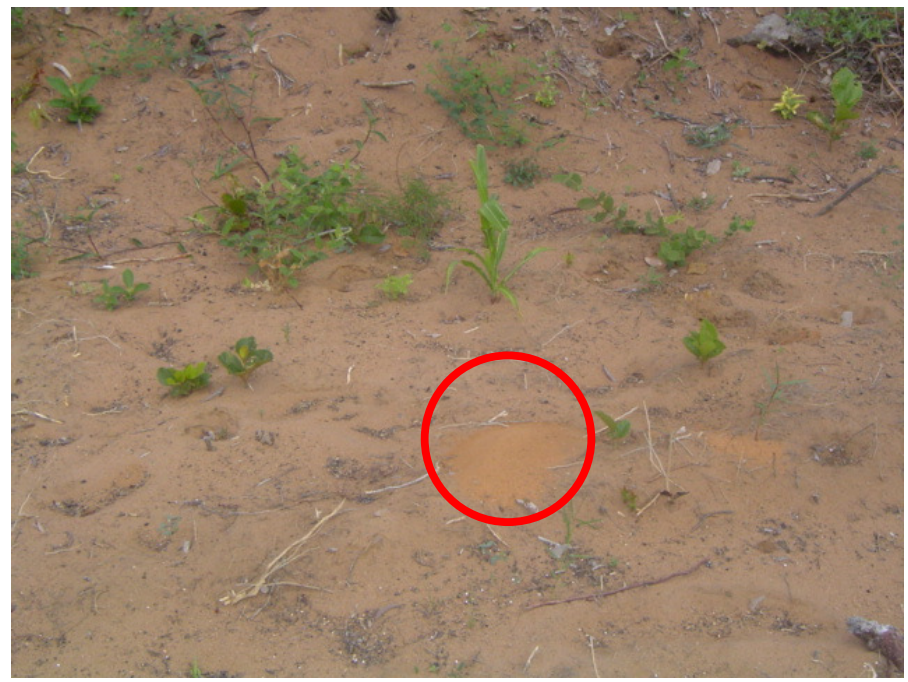

Figura 4.21 - Área de cultivo na Fazenda Piedade, plantio realizado no final de Jan/2005 (Detalhe das plantas de milho que não se desenvolveram).

Fonte: FEAM, Anexo Fotográfico (abril 2005).

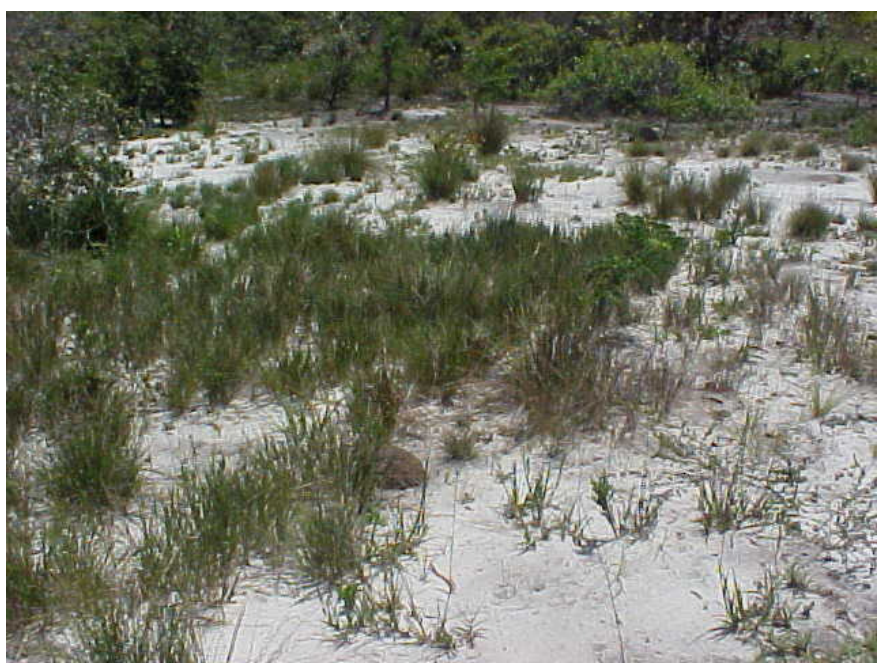

Figura 4.22 Fazenda Piedade em área de ocorrência de Areia Quartzoza (Classe de solo predominante em pelo menos três lotes).

Fonte: FEAM, Anexo Fotográfico (fevereiro 2005). 


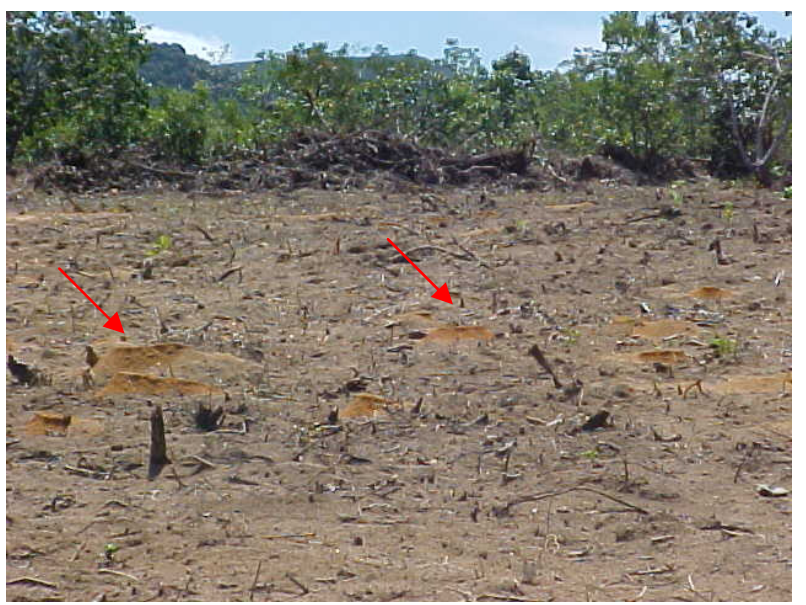

Figura 4.23 Fazenda Piedade - área destinada ao plantio com significativa densidade de formigueiros. (não se realizou combate a pragas).

Fonte: FEAM, Anexo Fotográfico (fevereiro 2005).

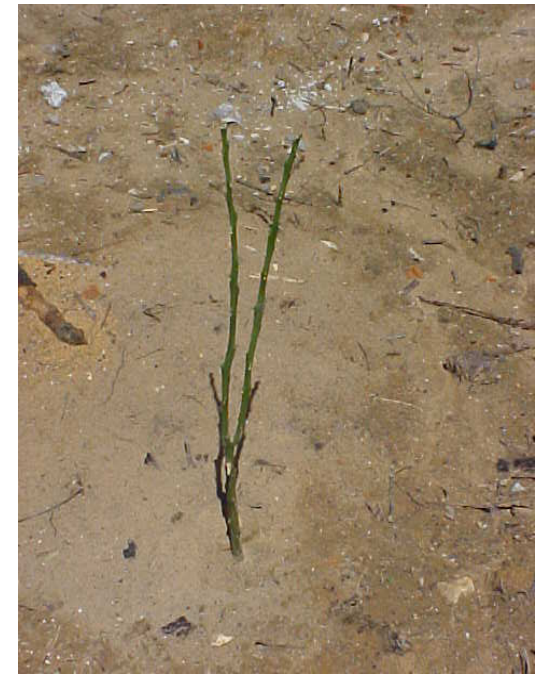

Figura 4.24 Fazenda Piedade. Muda de laranjeira atacada pela formiga.

Fonte: FEAM, Anexo Fotográfico (fevereiro 2005).

Os dados das tabelas 4.2 e 4.3 apresentam a relação de famílias e suas áreas de reassentamento, separadas em função da margem do Rio Jequitinhonha, uma relação refere-se à margem direita, e a outra, à margem esquerda. 
Tabela 4.2: Relação de Famílias reassentadas Margem Direita

\begin{tabular}{|c|c|c|c|}
\hline $\begin{array}{l}\text { Associação (Margem } \\
\text { Direita) }\end{array}$ & Município & Fazenda & $\begin{array}{l}\mathrm{N}^{\circ} \text { original } \\
\text { de famílias }\end{array}$ \\
\hline $\begin{array}{l}\text { Nova Esperança Faz. Rio } \\
\text { Preto }\end{array}$ & Francisco Dumont & Rio Preto & 29 \\
\hline \multirow{6}{*}{ União de Todos } & & Sul Brasil & 5 \\
\hline & & Oda & 8 \\
\hline & José Gonçalves de & Yamamura / Yokayama & 4 \\
\hline & Minas & Santo Antônio & 6 \\
\hline & & Progresso & 0 \\
\hline & & São Joaquim & 3 \\
\hline $\begin{array}{l}\text { Comunidade Coração de } \\
\text { Maria }\end{array}$ & $\begin{array}{l}\text { José Gonçalves de } \\
\text { Minas }\end{array}$ & Dileta & 20 \\
\hline Recanto Feliz & Diamantina & Riacho da Porta & 14 \\
\hline \multirow{3}{*}{$\begin{array}{l}\text { Peixe Cru p/Agric. Familiar e } \\
\text { Desenvolvimento }\end{array}$} & & $\begin{array}{l}\text { Campo Limpo / Peixe } \\
\text { Cru }\end{array}$ & 11 \\
\hline & Turmalina & Ribeirão das Caatingas & 2 \\
\hline & & $\begin{array}{l}\text { Boa Vista/ Córrego } \\
\text { Comprido }\end{array}$ & 14 \\
\hline \multirow[t]{3}{*}{ Amigos para Sempre } & Itamarandiba & São Bartolomeu - poço & 8 \\
\hline & & Conjunto Cachoeira & 9 \\
\hline & & Terça & 6 \\
\hline \multirow[t]{3}{*}{ União do Povo } & Itamarandiba & Santa Quitéria & 24 \\
\hline & & Cachoeira II & 7 \\
\hline & & Capão & 2 \\
\hline
\end{tabular}


(cont.)

Tabela 4.2

\begin{tabular}{|c|c|c|c|}
\hline $\begin{array}{l}\text { Associação (Margem } \\
\text { Direita) }\end{array}$ & Município & Fazenda & $\begin{array}{l}\mathrm{N}^{\circ} \text { original de } \\
\text { famílias }\end{array}$ \\
\hline $\begin{array}{l}\text { Quilombo Boa Sorte e } \\
\text { Agricultores Familiares } \\
\text { Reas. Faz. Boa Esperança }\end{array}$ & $\begin{array}{l}\text { Leme do } \\
\text { Prado }\end{array}$ & Mandassaia I e II & 40 \\
\hline $\begin{array}{l}\text { Agricultores Familiares } \\
\text { Reas. Faz. Boa Esperança }\end{array}$ & $\begin{array}{l}\text { Leme do } \\
\text { Prado }\end{array}$ & Contendas II & 7 \\
\hline $\begin{array}{l}\text { Reassentamento Conjunto } \\
\text { Mandassainha e Ventania }\end{array}$ & $\begin{array}{l}\text { Leme do } \\
\text { Prado }\end{array}$ & $\begin{array}{l}\text { Conj. } \\
\text { Mandassainha/Ventania }\end{array}$ & 18 \\
\hline Comunidade Coração de & Leme do & $\begin{array}{l}\text { Ribeirão Campo } \\
\text { Limpo/ Velho Texas }\end{array}$ & 7 \\
\hline Jesus & Prado & Palmital & 4 \\
\hline \multirow{2}{*}{$\begin{array}{l}\text { Associação da Fazenda } \\
\text { Fartura }\end{array}$} & \multirow[b]{2}{*}{ Capelinha } & Santa Bárbara & 7 \\
\hline & & $\begin{array}{l}\text { São Caetano } \\
\text { Fartura }\end{array}$ & 6 \\
\hline \multirow[b]{2}{*}{ Novo Horizonte } & \multirow[b]{2}{*}{ Água Boa } & Dallas & 13 \\
\hline & & $\begin{array}{l}\text { Ribeirão Vermelho/ } \\
\text { Cabeceira Surubim }\end{array}$ & 18 \\
\hline Boa Esperança (MD) & Angelândia & Três Moças & 9 \\
\hline
\end{tabular}

Fonte: PCA/ CEMIG, 2001.

As famílias reassentadas à margem direita ainda tiveram mais sorte que as da margem esquerda, como afirma Sr. José Antonio da Comissão dos Atingidos pela UHE de Irapé, "mas tem caso aí que tá complicado, não só na margem direita como na margem esquerda lá é pior, muito complicado".

Tabela 4. 3:Relação de Famílias reassentadas à margem esquerda 


\begin{tabular}{|c|c|c|c|}
\hline \multirow{3}{*}{ Boa Esperança (ME) } & & Barreiro II / Gurita & 3 \\
\hline & \multirow[t]{2}{*}{ Cristália } & Gangorrinha & 8 \\
\hline & & Sussuarana & 1 \\
\hline \multirow[t]{3}{*}{ Comunidade de Araras } & \multirow[t]{3}{*}{ Francisco Sá } & Araras & 24 \\
\hline & & Bom Jesus & 5 \\
\hline & & Gado Bravo / Gameleira & 2 \\
\hline \multirow[t]{3}{*}{ José Antonio } & \multirow[t]{3}{*}{ Botumirim } & Gilu & 3 \\
\hline & & Rocinha III & 2 \\
\hline & & Rocinha II & 2 \\
\hline \multirow{6}{*}{ Nova Bela Vista } & \multirow{6}{*}{ Botumirim } & Bela Vista I e II & 33 \\
\hline & & Pé de Serra & 3 \\
\hline & & Barreiras III & 1 \\
\hline & & Bonito & 3 \\
\hline & & Córrego dos Celso & 2 \\
\hline & & Olhos D'Água I e II & 3 \\
\hline \multirow[t]{9}{*}{ Nova Vida de Irapé } & \multirow[t]{9}{*}{ Botumirim } & Mumbuca & 4 \\
\hline & & Carlota / Sobrado & 1 \\
\hline & & Piabanha & 6 \\
\hline & & Piedade & 11 \\
\hline & & Córrego Fundo I e II & 6 \\
\hline & & Alvorada & 4 \\
\hline & & Aroeira & 7 \\
\hline & & Bananal & 3 \\
\hline & & Boa Vista II & 4 \\
\hline \multirow{7}{*}{ Nova Vida de Sussuarana } & \multirow{6}{*}{ Cristália } & Ferrador II & 3 \\
\hline & & Macaúbas / Bananal II e III & 7 \\
\hline & & Macaúbas / Ferrador & 5 \\
\hline & & Mumbuca II & 5 \\
\hline & & Altamira / Planalto & 3 \\
\hline & & São Mateus & 3 \\
\hline & & & (cont.) \\
\hline & & & (cont.) \\
\hline
\end{tabular}

Tabela 4.3 


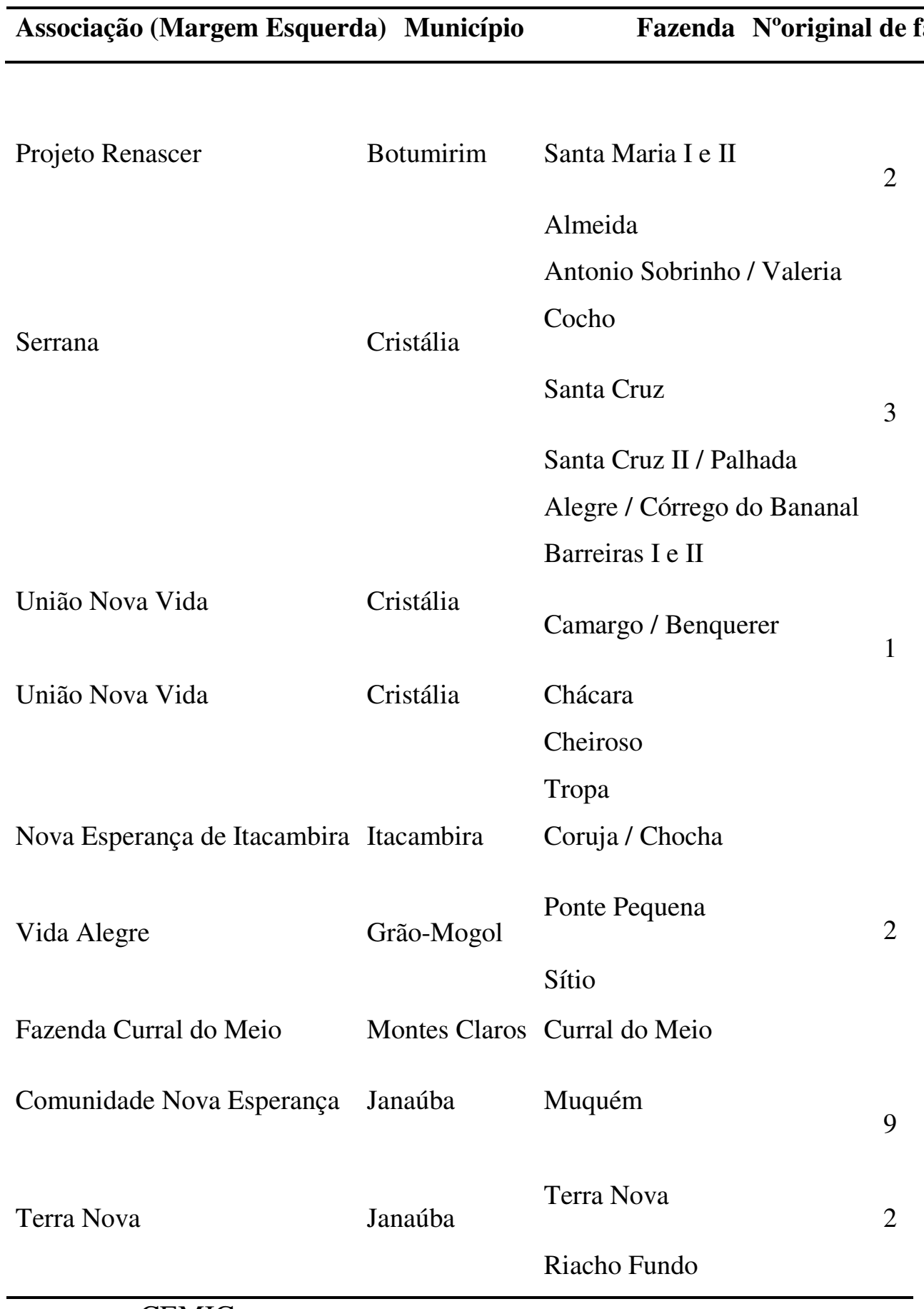

Fonte: PCA/ CEMIG, 2002

Estas relações estão incluídas no Plano de Controle Ambiental da CEMIG.

4.6 Acompanhamento do processo de cumprimento das condicionantes da UHE de Irapé e o desfecho da FEAM 
(...) bom né? Como resultado mesmo, a gente não viu, porque nossa participação terminou junto com a Licença de Operação que foi dada. Aí nosso setor acabou, passou por outro setor e tal, mas o que a gente sabe hoje em dia até pelo próprio Zé Antonio que, algumas comunidades, deram certo (Entrevista Mara Adelaide Pessoa Dutra na sede da FEAM, 21/11/2008, Belo Horizonte, MG).

No final da implantação dos reassentamentos, os técnicos da FEAM foram afastados da fiscalização e acompanhamento. Houve ruptura e ofensas por parte de alguns interessados no empreendimento, o que comprometeu negativamente a imagem dessess técnicos e, consequentemente, da Fundação.

(...) mas, então, veio à pressão para a LI, nesse ponto aí. E, assim, saiu nos jornais reportagens, falando mal da FEAM, falando mal da equipe da FEAM, nos chamando de corruptos é, estavam até ameaçando a fechar a FEAM (Entrevista Mara Adelaide Pessoa Dutra na sede da FEAM, 21/11/2008, Belo Horizonte, MG).

Os técnicos sofreram inúmeras repressões em vez da conduta assumida, além das ofensas relatadas em jornais. Também sofreram ameaças, com o intuito de serem intimidados.

(...) um deputado lá ameaçou a fechar a FEAM, que meia dúzia de funcionários tava atrapalhando e tal (...), chamaram os técnicos de "guardiões da miséria e por aí foi (Entrevista Mara Adelaide Pessoa Dutra na sede da FEAM, 21/11/2008, Belo Horizonte, MG).

Para a obtenção da Licença de Operação (LO), era preciso apresentar o cumprimento do Termo de Acordo, porém, a CEMIG estava com diversos problemas para a conclusão do Termo, o que dificultaria a emissão da referida Licença. Como afirma Morel Queiroz, técnico da FEAM, os técnicos enfrentaram inúmeros problemas em razão da fiscalização e dedicação, para que o Termo de Acordo fosse cumprido e, contrariamente, pelo reconhecimento do trabalho. A FEAM houve por bem encerrar as atividades do setor onde desenvolvia este trabalho de acompanhamento das obras de reassentamento dos empreendimentos em Minas Gerais, e emitiu a LO com inúmeros problemas ainda para serem resolvidos.

(...) apesar de toda a irregularidade, toda a flexibilização, toda adequação que eles fizeram (...) e o resultado apesar de tudo isso estendeu, e apesar também do descumprimento das obrigações ao longo da realização do projeto na etapa seguinte nós tivemos bastante 
problema. Esse é o primeiro momento, o segundo foi da implementação do que foi assumido de obrigação no Termo de Acordo. Aí foi uma patada, o resultado disso você não tem, acabaram com o setor (FEAM), a gente não trabalha mais com isso não, uai" (Entrevista Morel Queiroz na sede da FEAM, 21/11/2008, Belo Horizonte, MG).

Acreditamos que a função do Estado é defender os direitos da população, prestar serviços, como: saúde, educação, segurança e lazer em nome do bem-estar social. Infelizmente, o que vivenciamos, está se colocando em direção oposta ao bem-estar da humanidade. O Estado, hoje, beneficia uma pequena minoria que detém a maior parte da riqueza.

Ao analisarmos as questões "acordado" e a "realizada", percebemos que o empreendedor ficou muito aquém do exigido. O realizado mostra-se, para parte das comunidades, insuficiente, seja em termos dos detalhamentos como em termos de participação nas questões mais problemáticas enfrentadas pelas comunidades, após o reassentamento. Constata-se, portanto, o não cumprimento de compromissos importantes assumidos pelo empreendedor.

No próximo capítulo, abordaremos os custos apresentados pela CEMIG e seus direcionamentos. 


\section{CAPÍTULO V - CUSTOS APRESENTADOS PELA CEMIG}

\subsection{A inserção dos custos sociais nos custos de investimento}

A UHE de Irapé teve um investimento total de 1 bilhão e 900 milhões $^{22}$ de reais na obra. Com base nos dados levantados por meio do Estudo de Caso, acreditamos que se tornou possível indicar qual foi o "custo social" - definido no capítulo II - aproximado na UHE de Irapé. Para essa finalidade, foram considerados não só os números adquiridos com o empreendedor, como também o depoimento dos representantes, afirmando o valor pago.

A respeito dos valores gastos com os reassentamentos e as indenizações, pudemos perceber que tudo se restringe a programas ambientais, como mostra depoimento de um dos colaboradores da CEMIG:

Essa parte assim, de reassentamento e os programas ambientais, isso ficou junto, o que não é a obra de engenharia da barragem ficou em torno de 200 milhões de reais" (Entrevista com Guilherme Comitti, na sede da CEMIG, 18/11/2008, Belo Horizonte, MG).

Além do depoimento dos representantes da CEMIG, utilizamos como fonte o material enviado por e-mail por seus colaboradores. Não conseguimos abrir as contas e detalhar o quanto foi gasto com cada benfeitoria, indenização, aquisição de terras, porém, com bases nesses dados é possível identificarmos quanto os "custos sociais" representam, do investimento inicial, a questão social que, como vimos no capítulo anterior, não foi realizada de forma satisfatória.

A primeira tabela demonstra o valor apresentado pela CEMIG (2008), na aquisição das terras para os reassentamentos e pelas indenizações aos proprietários que optaram pela indenização monetária. Ao todo, a empresa gastou $\mathrm{R} \$ 54.100 .000,00$ (cinquenta e quatro milhões e cem mil reais) que contabilizam $2,84 \%$ do total gasto na obra.

\footnotetext{
${ }^{22}$ Conforme depoimento coletado em entrevista com o Sr. Wilson Grossi, 18/11/2008, Belo Horizonte,
} MG. 
Tabela 5. 1: Relação de Famílias reassentadas à Margem Esquerda

\begin{tabular}{llr}
\hline DESTINO & \multicolumn{1}{c}{ DESCRIÇÃO } & \multicolumn{1}{c}{ RECURSO } \\
\hline & todas as terras e respectivas \\
& benfeitorias $\quad$ existentes) \\
& utilizadas na implantação dos \\
Aquisição de terras & reassentamentos; & $\mathbf{R} \mathbf{5 4 . 1 0 0 . 0 0 0 , 0 0}$ \\
& Terras inundadas, cujos \\
& proprietários optaram pela \\
& indenização monetária;
\end{tabular}

Fonte: Arquivo da pesquisadora com base nos dados enviados pela CEMIG.

A próxima tabela demonstra os investimentos realizados para pagamento das indenizações e construção das casas nos reassentamentos.

\section{Tabela 5.2: Custos com Indenização}

\begin{tabular}{|c|c|c|}
\hline DESTINO & DESCRIÇÃO & RECURSO \\
\hline Indenizações & $\begin{array}{l}\text { Todos os pagamentos em } \\
\text { dinheiro a título de } \\
\text { indenização pelas benfeitorias } \\
\text { reprodutivas; } \\
\text { Culturas perenes e plurianuais } \\
\text { a preço de reposição + } \\
\text { produção cessante até a } \\
\text { primeira colheita; } \\
\text { Benfeitorias não reprodutivas } \\
\text { a preço de reposição (cercas, } \\
\text { curais, casa, etc.); }\end{array}$ & R\$ 15.300.000,00 \\
\hline Edificações & $\begin{array}{l}\text { Inclui a construção das casas } \\
\text { nos lotes de reassentamento e } \\
\text { a implantação do sistema de } \\
\text { abastecimento de água }\end{array}$ & $\mathrm{R} \$ 45.400 .000,00$ \\
\hline
\end{tabular}

Fonte: Arquivo da pesquisadora com base nos dados enviados pela CEMIG. 
Se analisarmos melhor os números, identificaremos que, para a construção de 638 casas ( ${ }^{\circ}$. de famílias optantes pelo reassentamento), considerando um valor de $\mathrm{R} \$ 19.344,00$ (dezenove mil trezentos e quarenta e quatro reais) - valor pago pelo empreendedor - temos $\mathrm{R} \$ 12.341 .472,00$ (doze milhões trezentos e quarenta e um mil quatrocentos e setenta e dois reais). Este valor foi o investimento realizado para a construção civil das casas aos reassentados. A quantia identificada para a construção das casas foi $27 \%$ menor do que os $\mathrm{R} \$$ 45.400.000,00 (quarenta e cinco milhões e quatrocentos mil reais). Podemos deduzir então que a quantia gasta com a implantação de abastecimento de água é de quase de $\mathrm{R} \$$ 33.058.528,00 (trinta e três milhões cinqüenta e oito mil e quinhentos e vinte e oito reais). $\mathrm{Ou}$ seja, se fizermos o processo contrário, identificamos que cada casa com a implantação do sistema de abastecimento de água representou para a CEMIG uma quantia de R $\$ 71.159,87$ (setenta e um mil cento e cinqüenta e nove reais e oitenta e sete centavos).

Este valor é questionável, quando percebemos que as casas não possuem materiais de qualidade, as portas empenaram, as paredes apresentam rachaduras, existem casas que foram demolidas duas vezes em função da qualidade, áreas com sérios problemas de acesso a água potável, o que não justifica o custo apresentado pelo empreendedor.

Os dados da próxima tabela trazem o valor dos recursos destinados para a construção dos reassentamentos e a descrição das atividades. 
Tabela 5. 3:Recursos destinados ao Desenvolvimento dos Reassentamentos

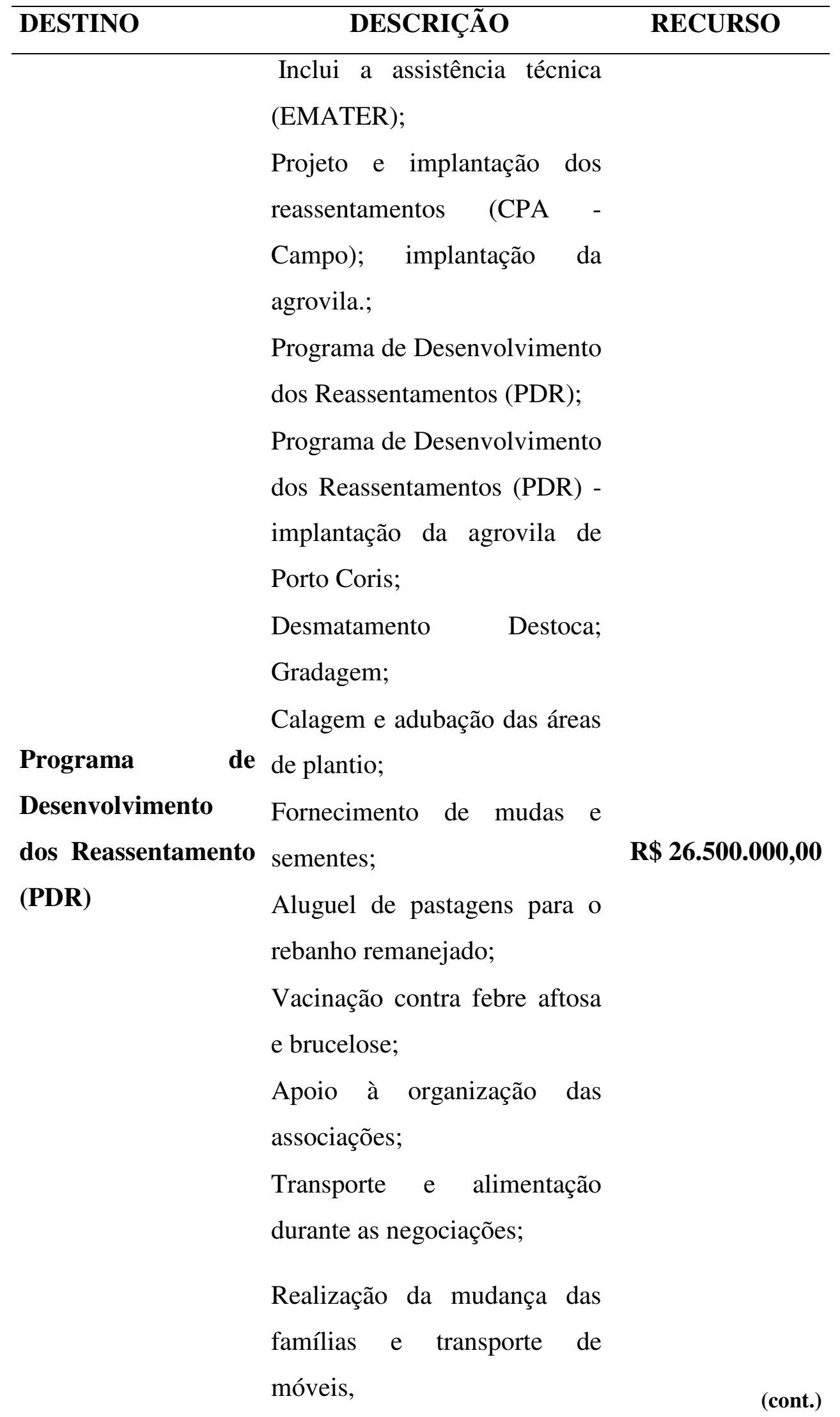




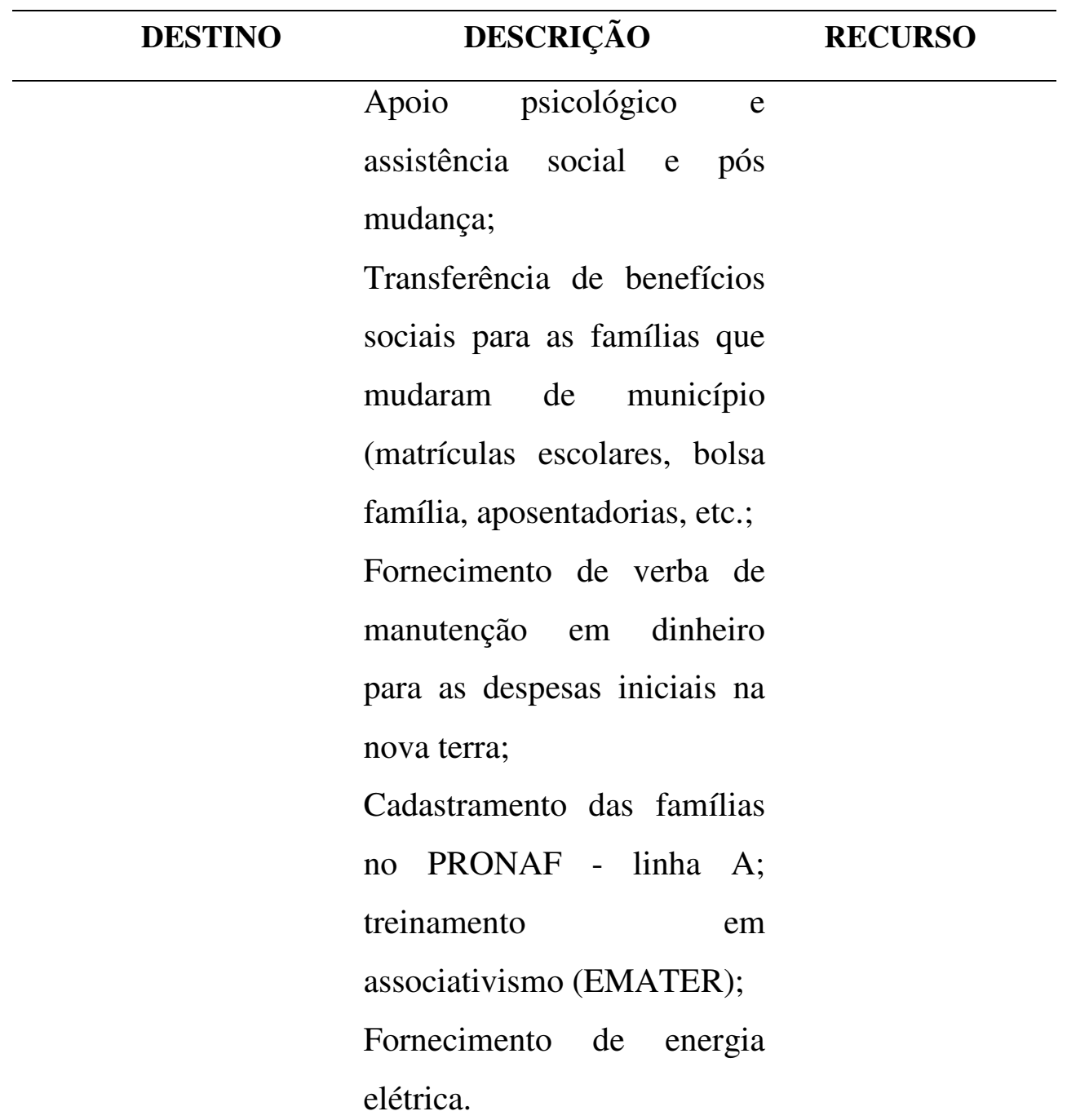

Fonte: Arquivo da pesquisadora com base nos dados enviados pela CEMIG.

Por fim, seguem os dados da Tabela 5.4 em que se demonstra o recurso destinado ao Plano de Controle Ambiental e obras do Reservatório, com a descrição dos locais de destino do recurso. 
Tabela 5. 4:Recursos destinados ao Plano de Controle Ambiental e Obras do Reservatório

\begin{tabular}{|c|c|c|}
\hline DESTINO & DESCRIÇÃO & RECURSO \\
\hline $\begin{array}{l}\text { Plano de Controle } \\
\text { Ambiental e Obras do } \\
\text { Reservatório }\end{array}$ & 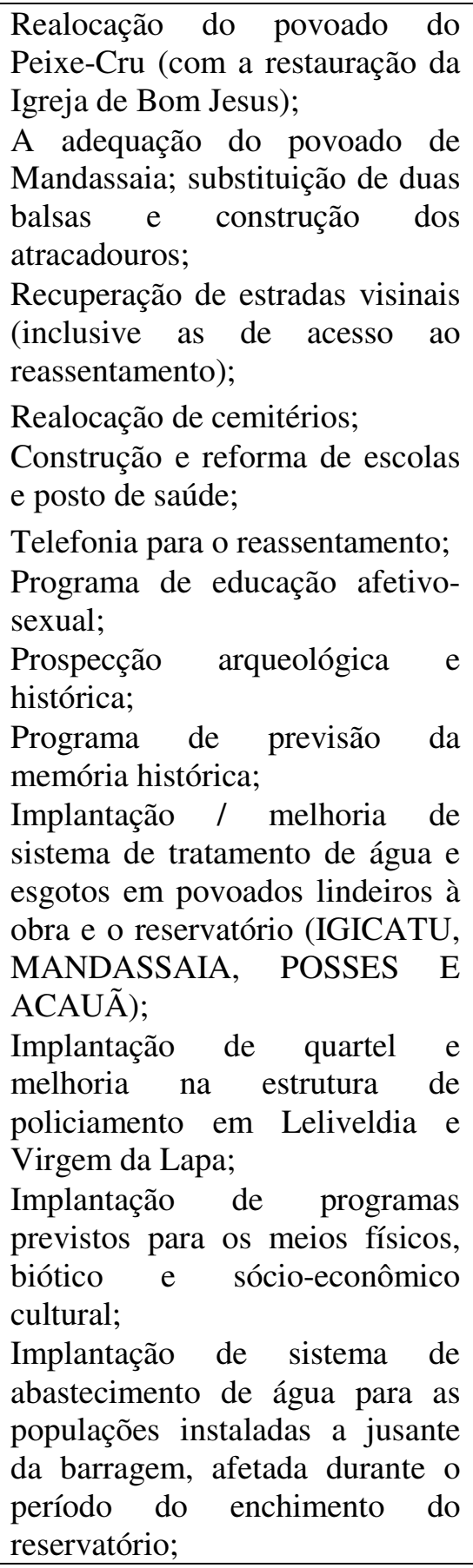 & R\$ 73.100.000,00 \\
\hline
\end{tabular}

Fonte: Arquivo da pesquisadora com base nos dados enviados pela CEMIG. 
Por fim, os dados da Tabela 5.5 mostram a quantia apresentada pela CEMIG para reparação dos "custos sociais" da UHE de Irapé.

Tabela 5. 5: Total dos Custos Sociais da UHE de Irapé

\begin{tabular}{|c|c|}
\hline DESTINO & RECURSO \\
\hline Aquisição de terras & $\mathrm{R} \$ 54.100 .000,00$ \\
\hline Indenizações & $\mathrm{R} \$ 15.300 .000,00$ \\
\hline Edificações & $\mathrm{R} \$ 45.400 .000,00$ \\
\hline Programa de Des. dos Reassentamentos & $\mathrm{R} \$ 26.500 .000,00$ \\
\hline Plano de Controle Ambiental & $\mathrm{R} \$ 73.100 .000,00$ \\
\hline
\end{tabular}

O montante apresentado pela CEMIG, de R \$ 214.400.000,00 (duzentos e quatorze milhões e quatrocentos mil reais), representa $11,28 \%$ do valor total de Investimento. Como foi demonstrado no capítulo IV, a CEMIG não cumpriu todas as condicionantes, e algumas condições para os reassentados ainda são precárias, como os problemas de manutenção para o abastecimento de água, o que gera um custo adicional para famílias que vivem da agricultura e de projetos sociais.

Conforme citado pelo Banco Mundial, as famílias deslocadas involuntariamente devem se encontrar em uma situação melhor ou igual à que estavam anteriormente. Só assim será possível medir se o investimento foi suficiente, ou não.

Apoiado na pesquisa documental foi possível identificar que, parte do dinheiro utilizado para compensação das transformações causadas, foi provisionada pelo executivo. Foram destinados no ano de 2001, R\$90.000.000,00 pela Lei $n^{\circ}$. 13.954 de 2001; o Executivo autorizou a envio para o empreendimento para ser utilizado nos reassentamentos das famílias atingidas (Assembleia Legislativa, 26/04/2006).

Já em 2006, o Projeto de Lei (PL) 2.953/2006 destinou recursos adicionais no valor de $\mathrm{R}$ \$ 30.000.000,00 com a mesma finalidade, para a conclusão do reassentamento das famílias atingidas pela barragem. Contudo, dos $\mathrm{R} \$ 214.400 .000,00$ gastos pela CEMIG para a reconstrução e com as indenizações, o Estado colaborou com 50\% do valor total gasto pela CEMIG. A responsabilidade direta nos "custos sociais" - reassentamentos, indenizações deveria ser do empreendedor, porém o Estado passou a ser credor dos processos de 
reassentamento causados pela Cemig, partindo do pressuposto de que a empresa é pública e a responsabilidade integral dos custos sociais acabou ficando com o contribuinte. 


\section{CONCLUSÃO}

Ao tomar como referência, as transformações sociais desencadeadas pelo deslocamento involuntário das populações que habitam áreas de construção de usinas hidrelétricas, verifica-se que existe um descaso por parte do Empreendedor e do Estado para o cumprimento da legislação a respeito dos direitos das populações. Dadas as limitações desta pesquisa, as indicações que se seguem, representam mais questionamentos e caminhos para futuras pesquisas do que conclusões propriamente ditas.

Como foi citado no início do trabalho, o objetivo foi apresentar como a noção de “custos sociais", é apreendida pela literatura, para então, demonstrar, por meio do estudo de caso, a apropriação de como a empresa trata a problemática.

O primeiro ponto a ser destacado, é a pretensão de se atribuir quantia as perdas. Isso provém da necessidade de penalizar os agressores "sociais". Assim, é preciso uma revisão da forma como os empreendedores consideram a questão social no planejamento inicial. Como vimos no Capítulo II, os planejadores "governamentais e setoriais acreditam (ou fingem acreditar) que uma simples abertura ao diálogo, por meio do chamado planejamento participativo, será suficiente para neutralizar as contradições e conflitos. Os movimentos são portadores de uma radicalidade que vai muito além: o desenvolvimento deve estar a serviço dos trabalhadores, da maioria da população regional/local" (VAINER ; ARAUJO, 1992, p.78).

Com isso, identificamos que, além de se considerar uma participação mais digna da população na decisão do investimento, é preciso incluir esses valores devem ser incluídos no total da obra; só assim será possível avaliar se o empreendimento é passível de viabilidade e se por meio de instrumentos transparentes as reais transformações locais forem demonstradas.

Assim, o processo de reparação, deve ser participativo, mas, para que o indivíduo seja reparado em suas perdas, ele precisará participar do processo.

No capítulo III entendemos e adentramos na questão do licenciamento e das características que transformam o Vale do Jequitinhonha em um local único e cheio de valores.

O IV capítulo, que chamamos de "acordado", foi elaborado com o intuito de tentar apresentar, o que foi assumido pelo empreendedor, a fim de demonstrar todo comprometimento de extrema importância, para o desenrolar de todo o processo de 
planejamento da reparação dos atingidos pela barragem de Irapé que diz respeito à organização e mobilização dos atingidos.

No V capítulo, foi possível sobrepor o "acordado" ao "realizado" e identificar que inúmeros itens assumidos no Termo de Acordo não foram cumpridos pelo empreendedor, gerando, na grande maioria, uma insatisfação quanto aos novos locais de moradia.

No VI capítulo, foi possível identificar quanto foi o montante gasto com a "reconstrução" das famílias atingidas. Levando em consideração o investimento de 1.900.000.000,00 (um bilhão e novecentos milhões de reais), a CEMIG informou que foram gastos cerca de $11 \%$ do valor total da obra com os projetos para reconstrução da população deslocada. Os custos sociais da UHE de Irapé foram e continuam crescentes.

Nesse sentido, o trabalho de campo confirmou que alguns atingidos referem que se encontram em melhores condições que antes do reassentamento, como a comunidade do Sr. José Antônio que se diz feliz com a nossa terra. Por outro lado, a maioria das comunidades não se encontra dessa forma.

Desse modo, observamos que exitem duas posições que melhor poderão ser exploradas posteriormente. Assim, a primeira cujos municípios não possuíam terras boas o bastante para a demanda; a segunda, diz respeito à declaração dos técnicos da FEAM que afirmam que a CEMIG "gastou mais" em comunidades para usar de "cenário" e replicar a realidade às demais.

Enfim, foi possível identificar que a reconstrução da questão social na UHE de Irapé acabou contrariando o argumento de progresso que a barragem traria à região. A situação descrita na região confirma a lógica capitalista, "ao introduzir e concentrar, num determinado espaço, grande quantidade de capital, acaba criando e aumentando a pobreza e a desigualdade da região" (VIANA, 2003).

Acreditamos que só será possível medir se os investimentos realizados com o deslocamento, indenizações e reassentamento da população foram feitos com justiça, se analisarmos o grau de satisfação das famílias. Mas não é possível definir, estipular ou formular uma porcentagem para cobrir esses custos. Dentro de nosso estudo, foi possível observar que, por mais significativo que seja o valor investido na questão social, os reassentamentos ainda não se encontram em um ambiente agradável, como o de Irapé, possuem inúmeros problemas com a qualidade das casas, dos terrenos, da água e outros problemas já identificados. 
Desse modo, é preciso estudar os interesses dos diferentes grupos sociais nas distintas formas de utilização da terra. Infelizmente faltou relatar o "esperado" pelos atingidos. Assim, seria possível consolidar a confirmação ou não da satisfação da população.

Observa que a questão não se encerra por aqui. A lacuna existente na literatura sobre os custos sociais tende a ser mais discutida, a fim de encontrar uma forma para a resolução dos conflitos existentes dentro dessa área. Um último ponto que deve ser levantado para investigações futuras diz respeito à construção de uma metodologia que considere a inserção da população no processo de decisão final para validar a viabilidade ou não do empreendimento.

Por fim, é preciso ressaltar que o Setor de energia deve aprender com os próprios erros, a fim de serem corrigidos e transformados em processos otimizados, pois uma constante aprendizagem impulsiona a construção de um progresso que visa, acima de tudo, e primordialmente, ao homem. 


\section{ANEXO A - E-mail valores apresentados pela CEMIG}

\section{Marcela Dadauto Lestingi}

De: $\quad$ "Guilherme Comitti" <Comitti@cemig.com.br>

Para: $\quad$ "Marcela Dadauto Lestingi" < marcelalestingi@iee.usp.br>

Cc: "Wilson Roberto Grossi" <wrgrossi@cemig.com.br>

Enviada em: terça-feira, 20 de janeiro de 2009 17:46

Assunto: RES: Dados UHE Irapé

Prezada Marcela,

Fiz uma pequena alteração na sua itemização, para agilizar a obtenção dos números que você precisa. Seguem os valores realizados em Irapé, em moeda de 2005

- Aquisição de Terrenos - R\$54,1 milhões - inclui todas as terras (e respectivas benfeitorias préexistentes) utilizadas na implantação dos reassentamentos + as terras da área inundada cujos proprietários optaram pela indenização monetária;

- Edificacōes - R\$ 45,4 milhōes - Inclui a construção das casas nos lotes de reassentamento e a implantação dos sistemas de abastecimento de água;

- Programa de Desenvolvimento dos Reassentamentos (PDR) - R\$26,5 milhōes - inclui a assistência técnica (EMATER); projeto e implantação dos reassentamentos (CPA - Campo); implantaçăo da agrovila de Porto Coris; desmatamento, destoca, gradagem, calagem e adubação das áreas de plantio; fornecimento de mudas e sementes; aluguel de pastagens para o rebanh remanejado; vacinação contra febre aftosa e brucelose; apoio à organização e formação das associaçōes; transporte e alimentaçăo durante as negociaçōes; realização da mudança das famílias e transporte de móveis, equipamentos e salvados de demolição; apoio psicológico e assistência social pré e pós mudanç; transferência de beneficios sociais para as familias que

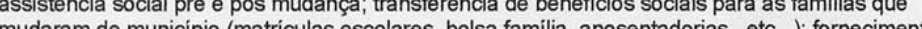
mudaram de municipio (matriculas escolares, bolsa famila, aposentadorias, etc...); fornecimento familias no PRONAF - linha A; treinamento em associativismo (EMATER); fornecimento de familias no PRONAF

- Indenizacōes - R\$ 15,3 milhões - inclui todos os pagamentos em dinheiro a titulo de indenização pelas benfeitorias reprodutivas (culturas perenes e pluri-anuais a preço de reposição + produção cessante até a primeira colheita) e benfeitorias não reprodutivas a preço de reposiçăo (cercas, currais, casas, etc...):

- Plano de Controle Ambiental e Obras do Reservatório - R\$ 73,1 milhões - inclui a relocação do povoado de Peixe Cru (com a restauração da Igreja de Bom Jesus); a adequação do povoado de Mandassaia; substituiçāo de duas balsas e construção dos respectivos atracadouros; recuperaçăo de estradas vicinais (inclusive as de acesso aos reassentamentos); relocação de cemitérios; construção e reforma de escolas e postos de saúde para atender aos reassentamentos; telefonia para os reassentamentos; programa de educação afetivo-sexual; prospecção arqueológica e histórica; programa de preservação da memória histórica; implantação/melhoria de sistemas de tratamento de água e esgoto em povoados lindeiros à obra e ao reservatório (Igicatu, Mandassaia; Posses e Acauã); implantação de quartel e melhoria na estrutura de policiamento em Lelivéldia e Virgem da Lapa; implantaçăo dos programas previstos para os meios físico, biótico e sócioeconômico cultural; implantação de sistemas de abastecimento de água para as populações instaladas à jusante da barragem, afetadas durante o período de enchimento do reservatório; etc..

O valor total do empreendimento ficou em R\$ 1.085 milhőes.

Espero ter atendido às suas necessidades. Qualquer dúvida, por favor entre em contato conosco.

Atenciosamente,

Guilherme

----Mensagem original--...

De: Marcela Dadauto Lestingi [mailto:marcelalestingi@iee.usp.br]

Enviada em: sexta-feira, 9 de janeiro de 2009 13:20

Para: Guilherme Comitti; Wilson Roberto Grossi

Assunto: Re: Dados UHE Irapé

Boa tarde

Obrigada, estou no aguardo.

Marcela

-.- Original Message -...

From: Guilherme Comitt

To: Marcela Dadauto Lestingi ; Wilson Roberto Grossi

Sent: Thursday, January 08, 2009 5:09 PM

Subject: RES: Dados UHE Irapé 


\section{ANEXO B - A luta dos Atingidos pela UHE de Irapé, Jornal local, Pelejando, outubro de}

2001.

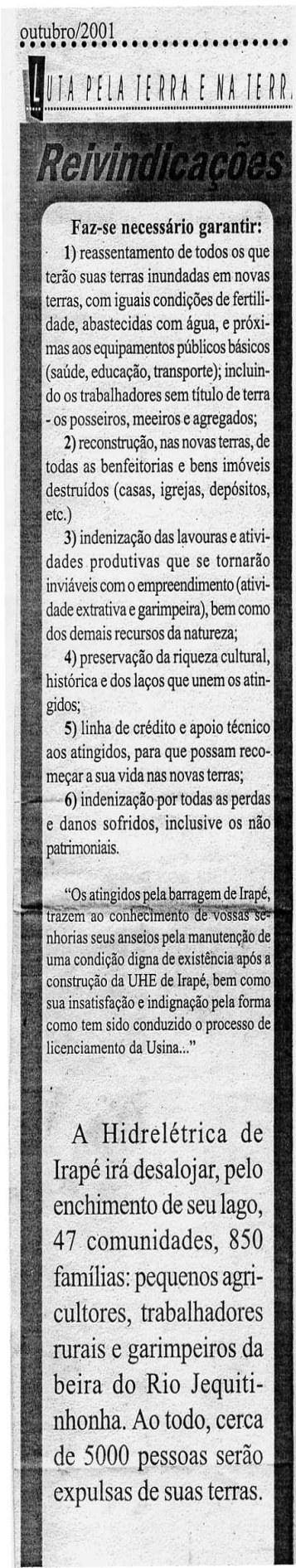

A luta dos atingidos pela U.H. de Irapé

Audiência Pública na Comissão de Direitos Humanos - ALMG

No dia 19 de setembro aconteceu, na Comissão de Direitos Humanos da Assembléia Legislativa de Minas Gerais,Audiência Pública envovendo os atingidos pela possivel construção da Usina Hidrelétrica de Irapé e diversas entidades que os apóiam, dentre as quais o Campo Vale, que lhes prestam assessoria há mais de 10 anos, e 0 CEDEFES, que juntos articularam a Audiência.

Pela grande mobilização social e politica ocorrida no dia, é possível considerar que a iniciativa foi um grande sucesso. Estiveram presentes diversos representantes da sociedade civil organizada, como a CNBB, a CPT, a FETAEMG, a Fundação Centro de Referência da Comunidade Negra e diversos professores universitários, apenas para citar alguns.

Além disso, a Audiência se mostrou bastante concorrida por diversos deputados que, normalmente, não têm demosntrado grandes interesses pelas açoes da Comissão de Direitos Humanos. Neste caso especifico, foram à audiência reproduziro discurso governamental e das elites locais do Jequitinhonh defendendo o "Progresso" e "redencõo" do Vale No entanto, seus discursos formm aind mais in

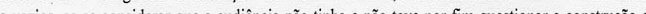
e dade ribeirinhas atingidas por sua construção.

Na parte da tarde os atingidos foram recebidos, ainda que a contra-gosto, pelo Presidente da CEMIG, que foi obrigado ao ouvir pacientemente as reivindicaçoes dos atingidos.

No dia 23 de outubro, acontecerá a $1^{2}$ Reunão da Comissão mista, formada đurante a audiência no dia 19 , para acompanhamento da Barragem de Irapé

"Somos moradores das terras mais férteis da regiào - a barranca do Jequitinhonha. Nossas comunidades tem carac terísticas muito próprias, vivendo mum delicado equilibrio com o ambiente natural, aprendido em mais de duzentos anos $d$ ocupaçào do. Vale. Trata-se de uma ocupação histórica, muitas vezes sem registro cartorial. Esse equilibrio dificilmente poderá ser reproduzido em outro lugar. Apenas para se ter uma ideia, area afetada conserva em até $70 \%$ a vegetação nativa, o que indica a convivência harmônica das comunidades ribeirinhas com o meio natural."

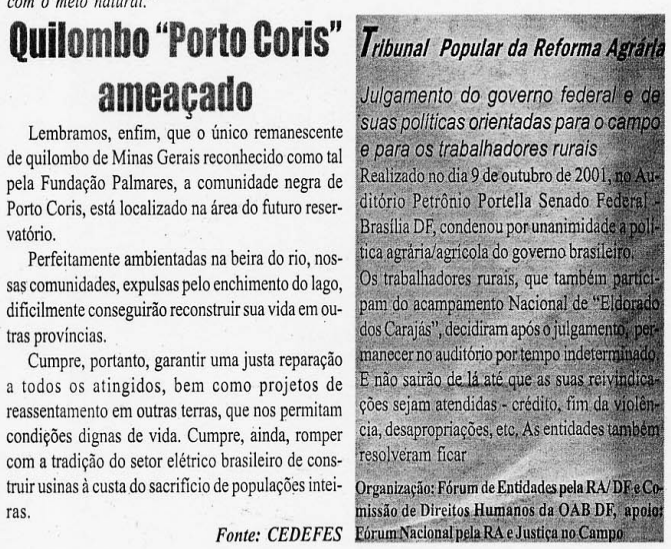




\section{Anexo C - Condições de alguns locais de reassentamentos}

\section{Condições de acessos para os reassentamentos}
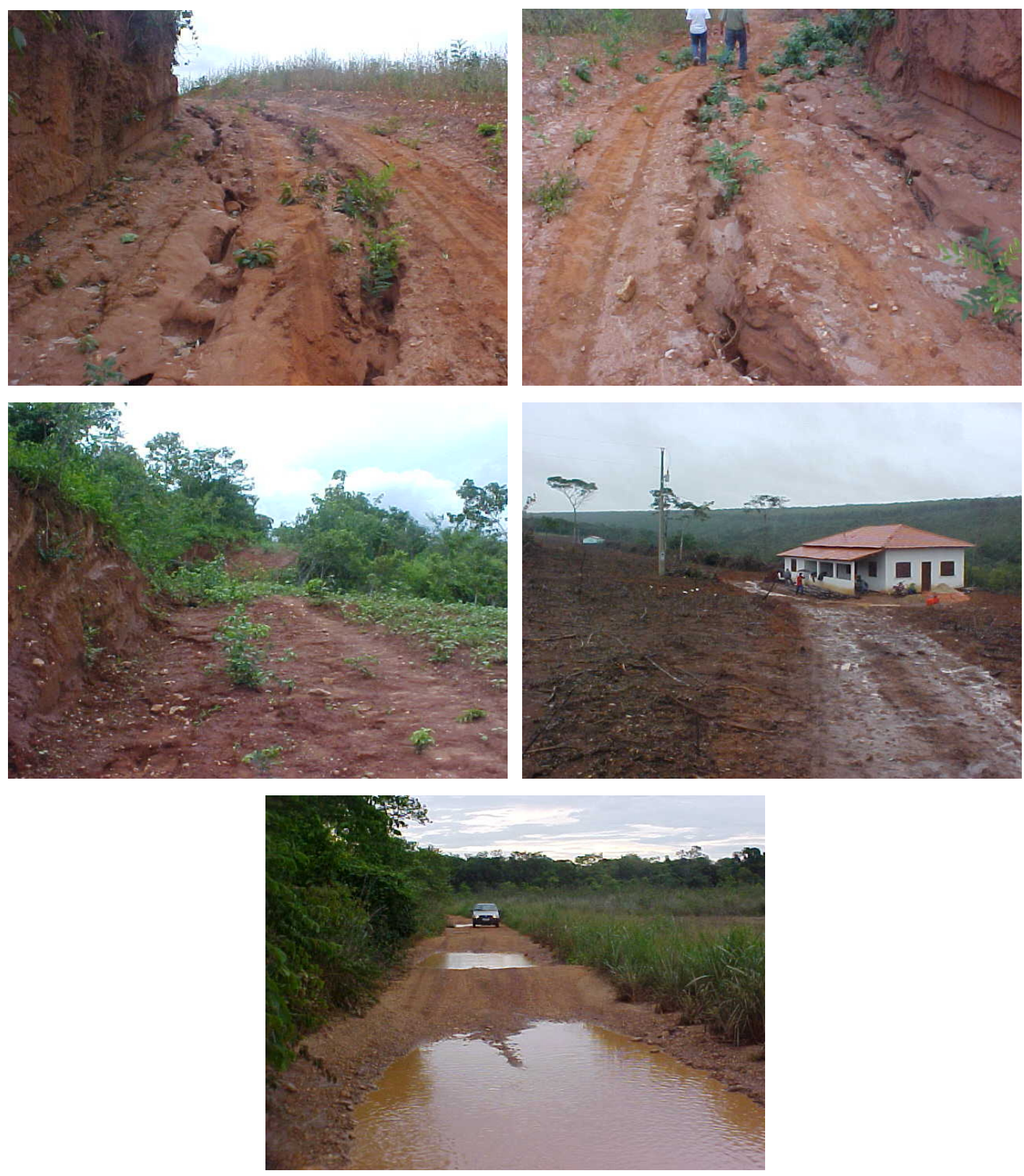

Fonte: FEAM, Relatórios de Vistoria (2005 1CD). 
Algumas áreas selecionadas para o reassentamento
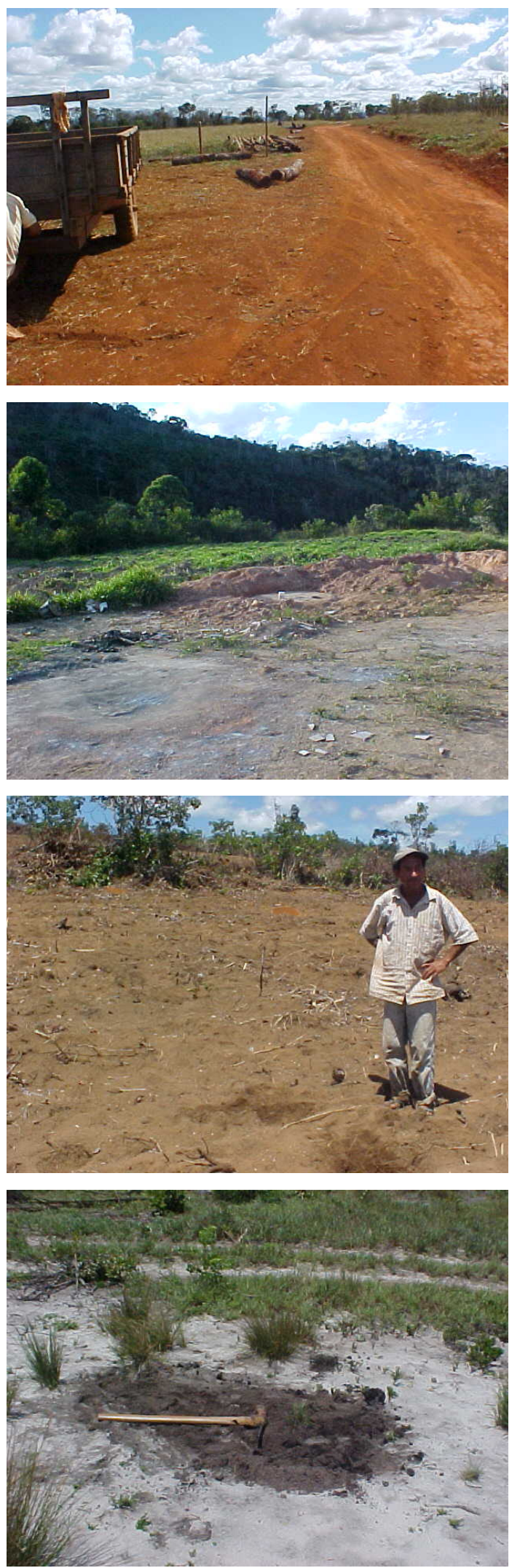

Fonte: FEAM, Relatórios de Vistoria (2005 1CD) 
Fazenda Dallas, casas em construção

Casas sendo construídas logo na curva da estrada
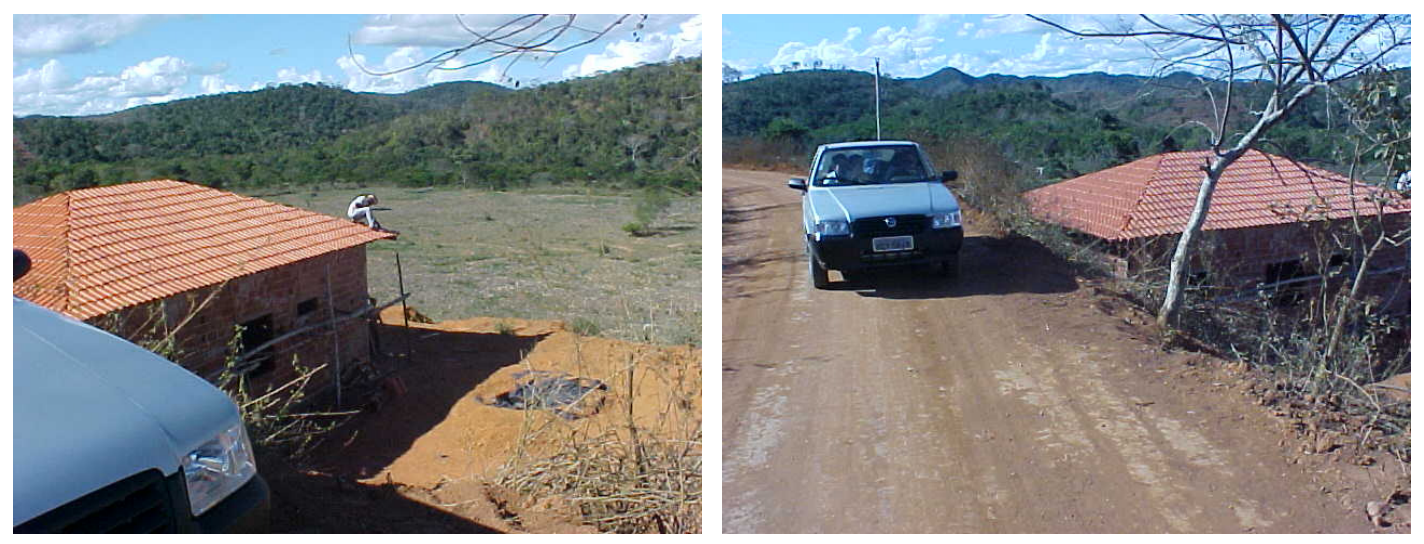

No fundo da casa uma erosão

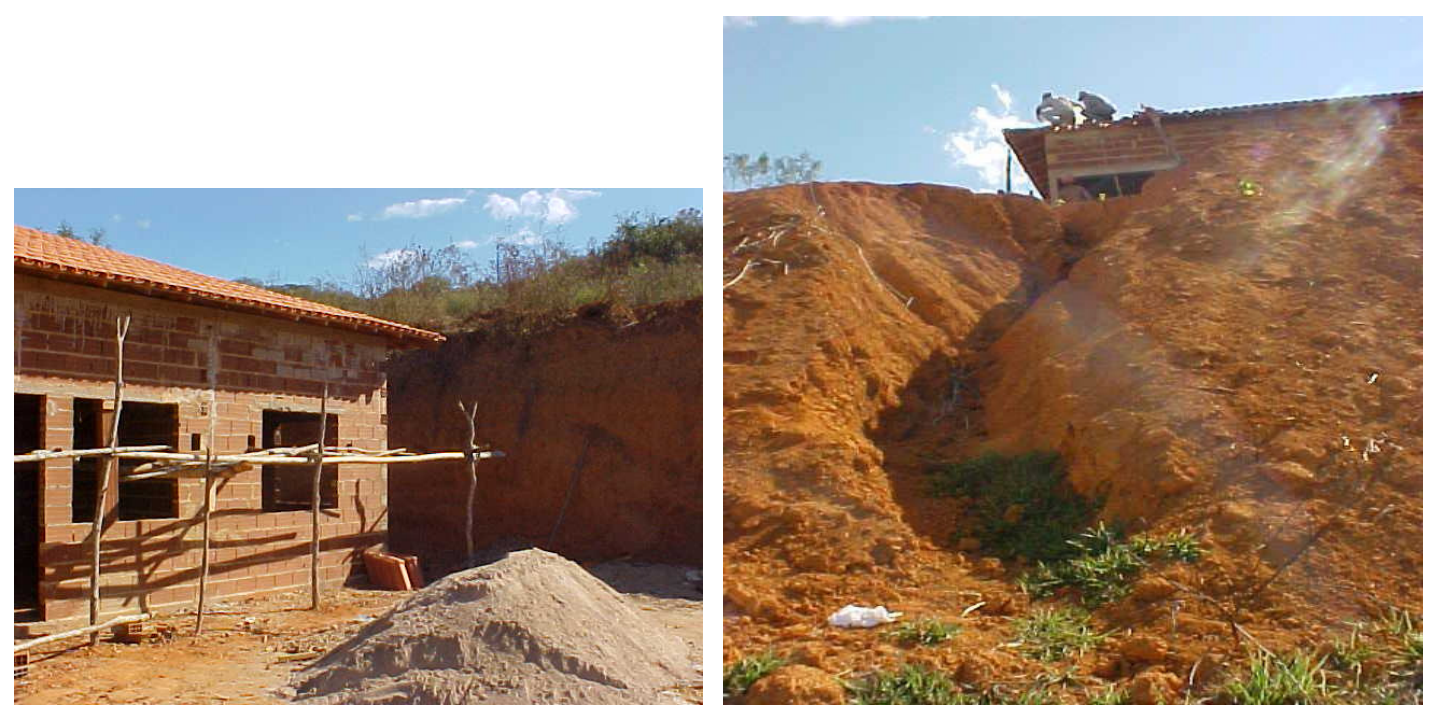

Fonte: FEAM, Relatórios de Vistoria (2005 1CD). 
Problemas apresentados nas casas antes da chegada das famílias:
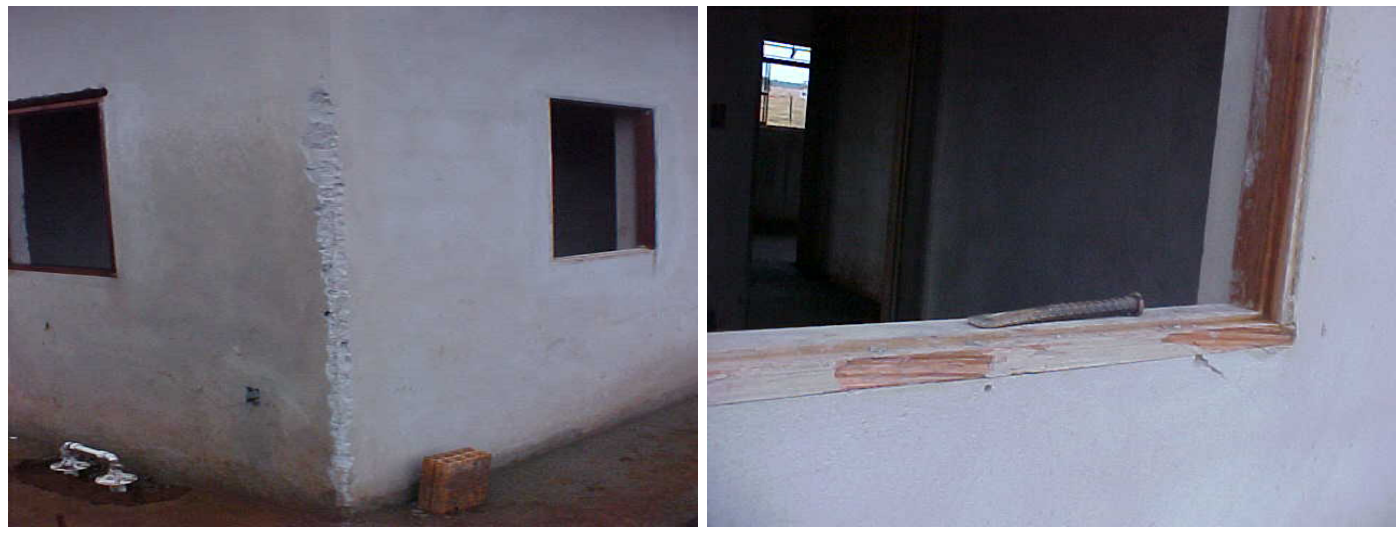

Rachaduras e trincas antes da finalização da construção
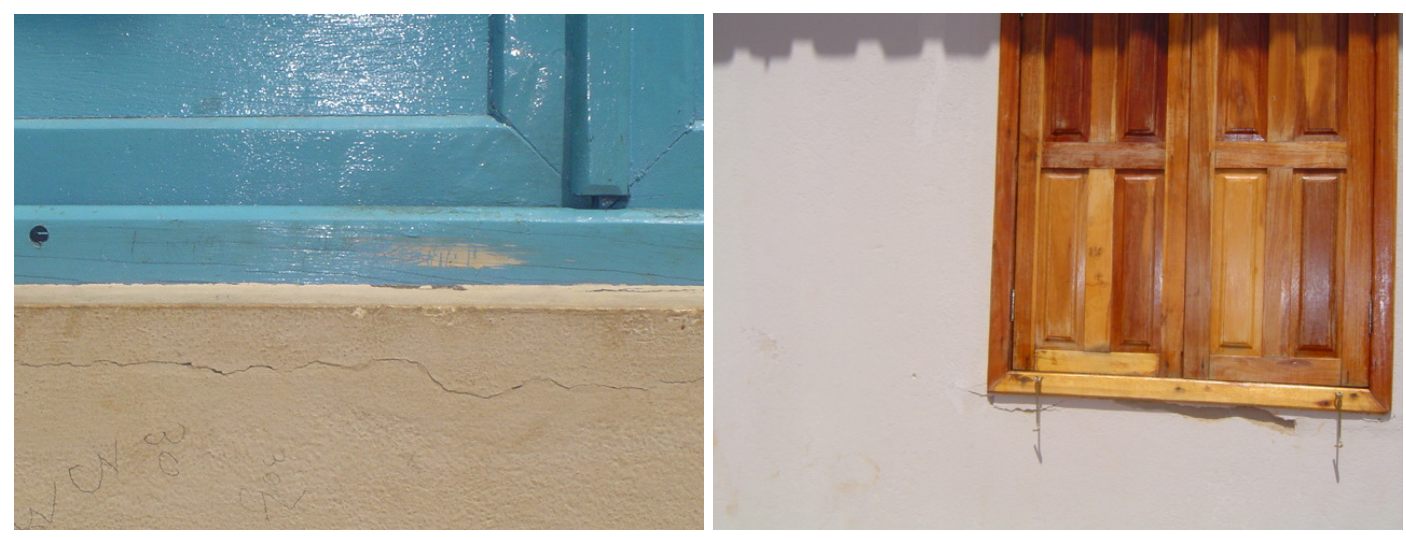

Bagunça na fiação

Problemas de vazamento
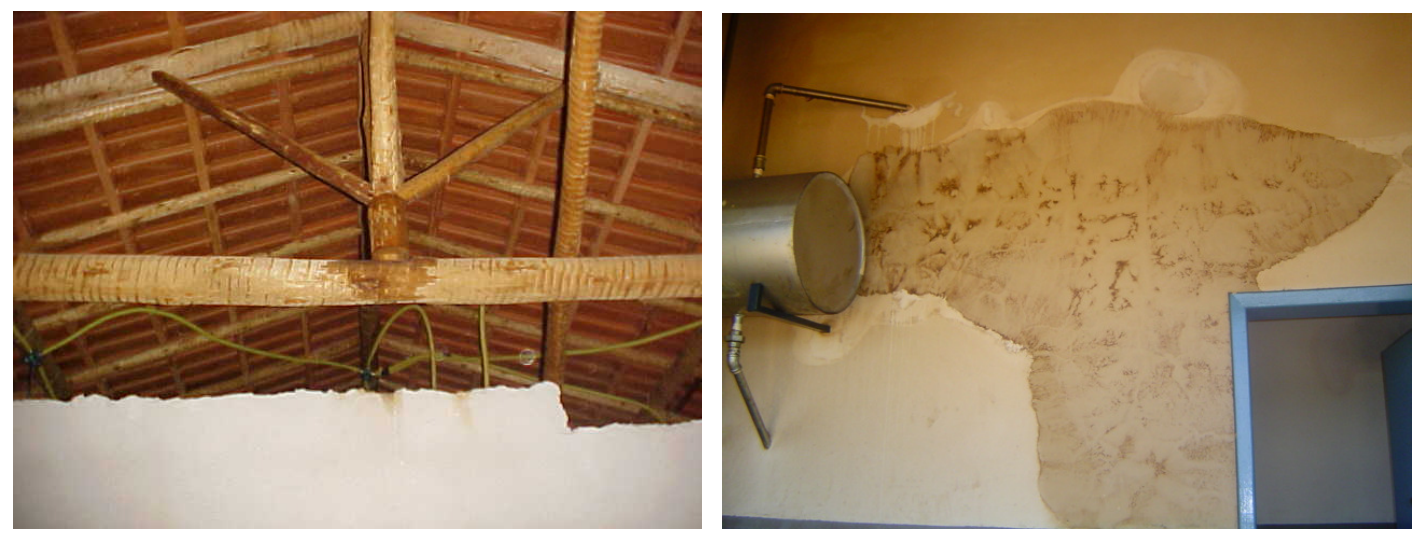

Fonte: FEAM, Relatórios de Vistoria (2005 1CD). 
Problemas com a construção dos telhados

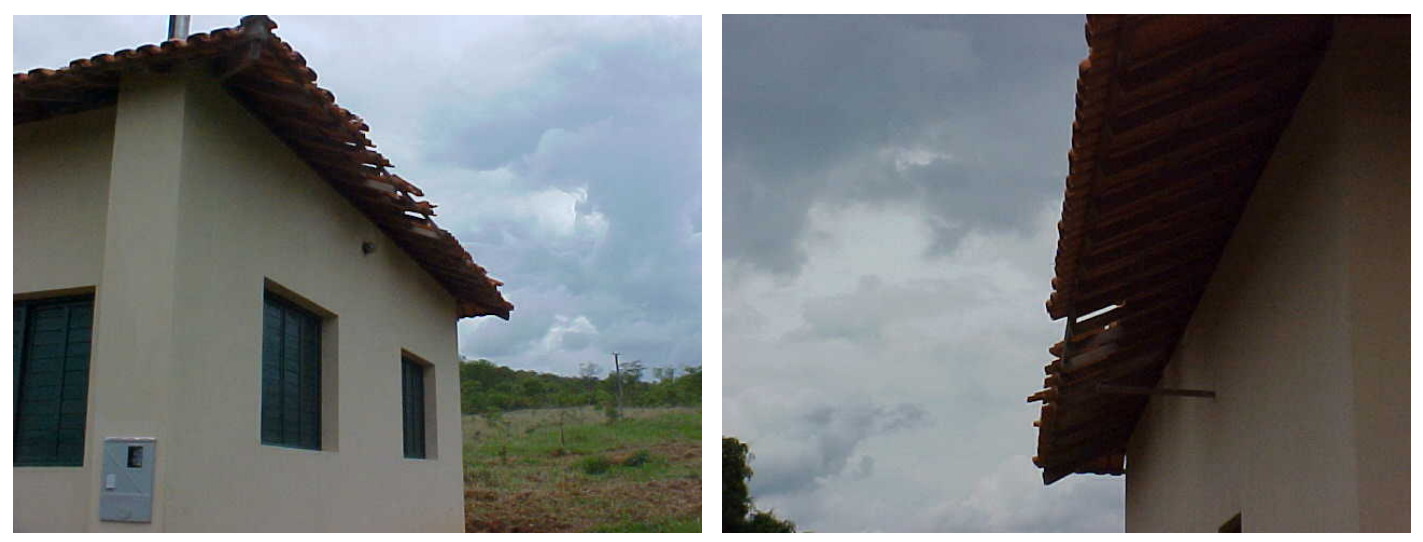




\section{REFERÊNCIAS BIBLIOGRÁFICAS}

ACSELRAD, H. (Org). Conflitos ambientais no Brasil. Rio de Janeiro: Delume-Dumara, 2004, p.211-213.

ANDRADE, L.M.M. As hidrelétricas do Xingu e os povos indígenas. [S.1] : Fundação PróÍndio, 1988.

ARENDT, H. A dignidade da política. Antônio Abranches (Org.). Trad. Helena Martins et. al.. Rio de Janeiro: Relume-Dumará. 1993

BERMANN, C. Energia no Brasil: Para quê? Para quem? Crise e alternativas para um país sustentável. 2. ed. São Paulo: Editora Livraria da Física, 2003. 139 p.

BERMANN, C. Reassentamento e Auto-Gestão : um estudo de caso: a barragems de Ita no sul do Brasil. Versão em português do trabalho "Self-managed ressettlement -case study of the Itá dam in Brazil" apresentado na Conferência Internacional "Hydropower into the next century: potential, opportunities, challenges", realizada em Barcelona em junho de 1995.

BERMANN, C. Indústrias Eletrointensivas e Autoprodução: propostas para uma política energética de resgate do interesse público. In: BERMANN, C. Exportando a Nossa Natureza Produtos Intensivos em Energia: implicações sociais e ambientais. Rio de Janeiro: FASE, 2004. Cadernos sobre Comércio e Meio Ambiente.

BERMANN, C. (Coord.) LESTINGI, M.D., MORENO, L.M. SAVOIA, R. ENERGIA EN BRASIL ¿PARA QUÉ Y PARA QUIÉN?. In: ESCENARIOS ENERGÉTICOS EM AMÉRICA DEL SUR: Integracion, Modelo Productivo, Energía: Aportes para um Debate Necesario. Oxfam y Fundacion Henrich Böll. Argentina: INERCIA, 2008.

BRASIL. Lei Federal nº.987 dispõe sob o aproveitamento energético de Irapé. Brasília 13.2.95.

BRASIL. GABINETE DA PRESIDÊNCIA. Constituição Federal. Brasília, 1988.

BURSZTYN, M. (org.). A Difícil Sustentabilidade: política energética e conflitos ambientais. 2. ed. Rio de Janeiro: Garamond, 2001. 259 p.

BANCO INTERAMERICANO DE DESENVOLVIMENTO. Reassentamento involuntário en los proyectos Del BID: princípios y lineamientos. Washigton D.C. Nov. 1999. 
CALIXTTO, J.; RIBEIRO, E.M.; GALIZONI, F.; SILVESTRE, L.H.; ASSIS, T.P.; AYRES, E.B. Agricultura familiar e programas de desenvolvimento rural no Alto do Jequitinhonha, Revista de Economia e Sociologia Rural, Brasília , v. 45, n. 4, out/dez, 2005.

CASA CIVIL. DECRETO N 6.040, DE 7 DE FEVEREIRO DE 2007. Institui a Política Nacional de Desenvolvimento Sustentável dos Povos e Comunidades Tradicionais.

COMPANHIA ENERGÉTICA DE MINAS GERAIS. Disponível em:

$<$ http://www.cemig.com.br/> . Acesso em : 10 ago. 2009.

Plano de Controle Ambiental : UHE de Irapé. Belo Horizonte , 2001. 3 volumes.

Apresentação PUC Minas Gerais, 2006. 1CD.

CERNEA, M. Hydropower Dams and Social Impacts: a sociological perspective. The World Bank, 1997. (Social Assessment Series, 044)

CERNEA, M. Riesgos de empobrecimiento y reconstrucción: un modelo para El desplazamiento y La relocalización de poblaciones. Revista Ava , nº5, 2004.

CERNEA, M..; McDOWELL, C. Risks and Reconstruction: experiences of resettlers and refugees. Washington, D. C.: The World Bank, 2000.

COLITO, E.M.C. A cosntrução de usinas Hidrelétricas e os impactos sobre a população e o espaço: unidades rurais ameaçadas pela Uhe de Jataizinho :Rio Tabaji-PA. Viçosa, Minas Gerais, 1999.

CONAMA, Resolução $\mathbf{N}^{\mathbf{0}}$. 001, de 23 de janeiro de 1986, publicado no D.O.U. de 17.02.1986.

DIENE/FEAM. UHE Fase Instalação: relatório acompanhamento da implementação das medidas ambientais. Fev de 2005. 1 CD-ROM.

DUPAS, Gilberto (Org.). Meio ambiente e crescimento econômico: tensões estruturais. São Paulo: UNESP, 2008, 298 p.

ECO, Umberto. Como se faz uma tese. 21. ed. São Paulo: Perspectiva, 2008. 172 p. 
FUNDAÇÃO ESTADUAL DO MEIO AMBIENTE . Anexo Relato Fotográfico, 2005. CDROM.

Relatórios de Vistoria, 2005. 1cd-rom.

FORO BOLIVIANO SOBRE MEDIO AMBIENTE Y DESARROLLO. Consideraciones sobre un megaproyecto: El Bala. LaPaz ,Bolívia: FOBOMADE, [19--]

GALIZONI, Flávia Maria. A terra construída: família, trabalho, ambiente e migrações no Alto Jequitinhonha. 2000. Dissertação (Mestrado)- Faculdade de Filosofia, Letras e Ciências Humanas, Universidade de São Paulo, São Paulo, 2000.

GALIZONI, Flávia Maria.; RIBEIRO, Eduardo Magalhães. Notas sobre água e chuva: Programa Um Milhão de Cisterna no semi-árido mineiro. 2004.In: ENCONTRO NACIONAL DE ESTUDOS POPULACIONAIS,14.,2004, Caxambú-MG. Anais..

GERMANI, Guiomar Inez. Expropriados Terra e Água: o conflito de Itaipu. 2. ed. Salvador: EDUFBA, 2003. 266 p.

GIL, Antonio Carlos. Como Elaborar Projetos de Pesquisa. 2. ed. São Paulo: Atlas, 1989. $159 \mathrm{p}$.

GOLDEMBERG, José \& VILlanUEVA, Luz Dondero. Energia, Meio Ambiente \& Desenvolvimento. São Paulo: Editora da Universidade de São Paulo, 2003.

ITACARAMBY. K. A desterritorialização forçada de comunidades tradicionais: Casos de injustiça sócio ambiental. 2006. Dissertação (Mestrado) Universidade de Brasília, 2006.

JERONYMO, Alexandre Cosme José Deslocamentos de populações ribeirinhas e passivos sociais e econômicos decorrentes de projeto de aproveitamento hidrelétrico: a usina hidrelétrica de Tijuco Alto/SP-PR. 2007. 173p. Dissertação (Mestrado em Energia) Programa Interunidades de Pós-Graduação em Energia da Universidade de São Paulo, 2007

JORNAL ESTADO DE MINAS. Famílias estão sem água e endividadas. 11/02/2007.

JORNAL ESTADO DE MINAS. Lago no Deserto. 31/08/2008. 
LEFF, Enrique. Saber ambiental: sustentabilidade, racionalidade, complexidade, poder. Petrópolis: Vozes, 2007.

MARTÍNEZ, Alier Juan; SCHLÜPMANN, Klaus. La Ecología y La Economía. México: Fondo de Cultura Económica, 1991.

MARTÍNEZ, Alier Juan. O ecologismo dos pobres: conflitos ambientais e linguagens de valoração. São Paulo: Contexto, 2007.

MANKIW, N. Gregory. Introdução à Economia. Rio de Janeiro: LTC, 2005.

MOURA, L.A.A. Economia Ambiental Gestão de Custos e Investimentos. Editora Juarez de Oliveira, São Paulo, 2002.

MINISTÉRIO PÚBLICO FEDERAL. Brasil. Análise do EIA/RIMA do empreendimento AHE Serra do Facão, no rio São Marcos (GO/MG). (INFORMAÇÃO TÉCNICA n. ${ }^{\circ}$ $185 / 2004-4^{\mathrm{a}}$ CCR).

MINISTÉRIO PÚBLICO DO ESTADO DE MINAS GERAIS. Termo de Acordo estabelecido entre o MPF, Estado de Minas Gerais, CEMIG e FEAM com intervenção da Fundação Cultural Palmares, Associação Quilombola Boa Sorte e da comissão de Atingidos pela Barragem de Irapé. Belo Horizonte: Procuradoria da República em Minas Gerais. 2002.

PINHEIRO, Maria Fernanda Bacile.; SEVÁ, Arsênio Oswaldo Filho. Expansão Hidrelétrica no período 2003-2006: confitos sociais e institucionais em novas represas e nas concessões leiloadas. In: ENCONTRO DA ASSOCIAÇÃO NACIONAL DE PESQUISA E PÓS-GRADUAÇÃO EM AMBIENTE E SOCIEDADE, 3., 2006, Brasília. Anais. Brasília, 2006.

PINHEIRO, Maria Fernanda Bacile. Problemas sociais e institucionais na implantação de Hidrelétricas: seleção de casos recentes no Brasil e casos relevantes em outros países. Dissertação( Mestrado) - Programa de Pós-Graduação em Engenharia Mecânica, Planejamento de Sistemas Energéticos, Universidade Estadual de Campinas, . Campinas, 2007.

REBOUÇAS, Lidia Marcelino. O Planejado e o vivido. O reassentamento de famílias ribeirinhas no Pontal do Paranapanema. São Paulo: Annablume: Fapesp, 2000.194p. 
RIBEIRO, Ricardo Ferreira. Mudando para continuar sendo: a organização de movimentos de atingidos por barragens no Vale do Jequitinhonha In: ROTHMAN, Franklin Daniel. Vidas alagadas : conflitos socioambientais, licenciamento e barragens. Viçosa, MG: UFV, 2008. $344 p$.

ROTHMAN, Franklin Daniel. Vidas Alagadas: conflitos socioambientais, licenciamento e barragens. Viçosa: UFV, 2008. 344p.

SANTOS, Márcio Roberto Alves dos. Irapé: paisagem cultural e paisagem tecnológica. Belo Horizonte: Assembléia Legislativa do Estado de Minas Gerais, Escola do Legislativo, 2007. 12 p.Relatórios do NEPE.

SANTOS, Sílvio Coelho dos.; NACKE, Aneliese (Org.). Hidrelétricas e Povos Indígenas. Florianópolis: Letras Contemporâneas, 2003. Cap.1, 2, 3, p. 9-83.

SCARPINELLA, Claudio Antonio. Porto Primavera: o paradigma de análise e os processos de decisão e implantação. São Paulo: USP, 1999. 156 p. Tese (Doutorado) - Programa Interunidades de Pós-Graduação em Energia da Universidade de São Paulo, São Paulo, 1999.

SHIRAISHI Joaquim, Neto. (Org.). Direito dos Povos e das Comunidades Tradicionais no Brasil: declarações, convenções internacionais e dispositivos jurídicos definidores de uma política nacional. Manaus: UEA, 2007. 224p. Documento de bolso; $\mathrm{n}^{\circ}$.I

SEVÁ, Oswaldo. Usinas hidrelétricas e termelétricas: roteiro experimental sobre as concepções e o modo de funcionamento e sobre algumas das consequências. 2005.In: SEMANA DE ENGENHARIA MECÂNICA UNICAMP, 9.,2005, Campinas. Anais.

SEVÁ, Oswaldo. Tentativas hidrelétricas nos rios Xingu paraense e Madeira : mamoré internacional. 2007. ENCONTRO CIÊNCIAS SOCIAIS E BARRAGENS, 2., 2007, Salvador. Anais. Povos e comunidades tradicionais da Amazônia atingidas e ameaçadas por barragens, 2007.

SEVÁ, O. Estranhas catedrais. notas sobre o capital hidrelétrico, a natureza e a sociedade. Ciência e Cultura, Energia Ambiente e Sociedade . Ciência e Cultura, v.60; n.3, set. , 2008.

SIGAUD, L. Implicações Sociais da Política do Setor Elétrico. In: SANTOS, L. e ANDRADE, L. As Hidrelétricas do Xingú e os Povos Indígenas. São Paulo: Comissão PróÍndio, 1988 
SOARES, D.F. Grandes projetos de infraestrutura e perdas irreparáveis: os impactos impagáveis e inapagáveis provocados pela construção de usinas hidrelétricas. In: WORKSHOP GLOBALIZAÇÃO, POLÍTICAS TERRITORIAIS, MEIO AMBIENTE E CONFLITOS SOCIAIS, 2006, Itamonte. Caderno de Resumos. Itamonte, MG., 2006.

VAINER, Carlos B. ; ARAUJO, Frederico Guilherme B. de. Grande Projeto de Investimento e região: algumas proposições In: Grandes projetos hidrelétricos e desenvolvimento regional., Rio de Janeiro: Centro Ecumênico de Documentação e Informação, 1992. p.. 4049.

VAINER, Carlos B. O conceito de atingido: uma revisão de debates e diretrizes. Rio de Janeiro: Nuprelo. 2003.

VEYRET, Yvette (Org.). Os Riscos: o homem como agressor e vítima do meio ambiente. São Paulo: Contexto, 2007.

VIANA, Raquel de Matos. Grandes barragens, impactos e reparações: um estudo de caso sobre a barragem de Itá. Dissertação (Mestrado) - Programa de Pós-Graduação em Planejamento Urbano e Regional, Universidade Federal do Rio de Janeiro, Rio de Janeiro, 2003.

WERNKE, Rodney ; BORNIA, Antonio Cezar. A Contabilidade Gerencial e o Métodos Multicriteriais. Revista Contabilidade \& Finanças, São Paulo, v.14, n.25, p. 60-71, jan./abr. 2001.

WORLD BANK. Land Acquisition \& Resettlement Guidelines. p-7-9.

WORLD COMMISSION ON DAMS. Dams and development: a new framework for decision-making. London: Earthscan Publications, 2004.

ZHOURI, A. A Re-volta da ecologia política In: ACSELRAD, H (Org). Conflitos Ambientais no Brasil. Rio de janeiro: Delume-Dumara, 2004, p.211-213.

ZHOURI, A. \& OLIVEIRA, R. Paisagens Industriais e Desterritorialização de Populações locais: conflitos socioambientais em projetos hidrelétricos. In: ZHOURI, A. LASCHEFSKI, K; PEREIRA, D. (Org.). A insustentável leveza da política ambiental. Desenvolvimento e conflitos socioambientais. Belo Horizonte: Ed. Autêntica. 2005.

ZHOURI, A. \& OLIVEIRA, R.. Desenvolvimento, Conflitos Sociais e Violência no Brasil Rural: o Caso das Usinas Hidrelétricas. Ambiente e Sociedade, Campinas, v.10, n.2, 
p 119-135, jul-dez., 2007.

ZUCARRELli, Marco. Estratégias de Viabilização Política da Usina de Irapé: o (des)cumprimento e normas e o ocultamento de conflitos no licenciamento ambiental de hidrelétricas. Dissertação (Mestrado) - Programa de Pós-Graduação em Sociologia, Universidade Federal de Minas Gerais, 2006.

CONSELHO NACIONAL DO MEIO AMBIENTE. Medida Provisória nº 2.147 , de 15 de maio de 2001.

Documentos em meio eletrônicos:

RHAMA - Consultoria, Pesquisa e Treinamento Ambiental. Disponível em: <http://www.rhama.net/areasatuacao_avaliacao.asp >. Acesso em: 06 maio 2010.

MACHADO, G.L.; FARRER, G. Grito de Socorro - desasatre ambiental e social no Jequitinhonha. Disponível em:

$<$ http://midiaindependente.org/pt.blue/2009/04/445601.shtml > . Acesso em: 21 ago.2009.

UHE Irapé. Disponível em: <http://www.irape.com.br/programas/index.asp >. Acesso em : 18 jul.2008.

ONG Campo Vale. Informações disponível em:

<http://www.nead.org.br/index.php?acao=ongs\&id=20>. Acesso em 22 nov. 2009.

Região do Vale do Jequitinhonha. Disponível em:

http://pt.wikipedia.org/wiki/valedojequitinhnha. Acesso 17/06/2008. 